University of Oklahoma College of Law

University of Oklahoma College of Law Digital Commons

American Indian and Alaskan Native Documents in the Congressional Serial Set: 1817-1899

2-25-1892

\title{
Jurisdiction of the Supreme Court
}

Follow this and additional works at: https://digitalcommons.law.ou.edu/indianserialset

Part of the Indigenous, Indian, and Aboriginal Law Commons

\section{Recommended Citation}

S. Rep. No. 281, 52nd Cong., 1st Sess. (1892)

This Senate Report is brought to you for free and open access by University of Oklahoma College of Law Digital Commons. It has been accepted for inclusion in American Indian and Alaskan Native Documents in the Congressional Serial Set: 1817-1899 by an authorized administrator of University of Oklahoma College of Law Digital Commons. For more information, please contact Law-LibraryDigitalCommons@ou.edu. 


\section{IN THE SENATE OF THE UNITED STATES.}

Frbruary 25, 1892.-Ordered to be printed.

Mr. MorgaN, from the Committee on Indian Affairs, submitted the following

\section{REPORT:}

[To accompany \$. 1548.]

The Committee on Indian Affairs, to whom was referred the bill (S. 1548) to extend the jurisdiction of the Supreme Court of the United States as defined in section 709 of the Revised Statutes, etc., submit the following report and accompanying papers, and recommend the passage of the bill:

The effect that is to be given to the judgments of the tribal courts, based upon their written constitutions, and the laws enacted by the legislatures of five civilized tribes-especially with reference to the disposal of their lands within the undisputed limits of their national boundaries to their own people-is a matter of the deepest concern to the tribes, the individual Indians, and to the Government of the United States. To postpone a satisfactory and final decision of this subject to a future period will invite confusion, distrust, and civil strife in that entire country.

The bill reported by the committee (S. 1548) appears to be the best if not the only means of reaching a just, satisfactory, and indisputable decision and settlement of these questions.

As a matter of constitutional power, the enactment of laws by Congress to define and regulate the political status of these five tribes can not be disputed. Any declaration in our treaties, or in existing statutes, as to the mere political right of the Indians to have and conduct local self-government, must yield to the power of Congress to repeal the mere political features of such treaties and statutes whenever they are found to be inconsistent with and injurious to the general welfare of the people of the United States.

This power has often been declared, both in acts of Congress and in the decisions of the Supreme Court of the United States. But when a proprietary right is vested in any grantee by a treaty, the repeal of the treaty does not affect the right. Especially is this true of grants of land by fixed boundaries, which have been demarked and ratified by anthority of the legislature and recognized by the executive and judicial departments of the Government.

Neither can the power to dispose of lands so granted be afterward taken away when that power is one of the elements of the grant and is made necessary by the terms of the treaty or by the then existing conditions in order to the full execution of the purposes of the grant. The grant and the power to completely execute it are equally the right of 
the grantee, unless some other provision is made in the treaty, and they together become vested and undeniable'rights. The five tribes bought the lands they occupy west of the Mississippi from the United States and paid for them a full consideration.

No patentee has a better title to his land than was derived by these five tribes, separately, from the United States.

Along with this grant of titles made in treaties, sanctioned by acts of Congress and the uniform action of the executive and judicial departments of the Government of the United States, and evidenced by letters patent sealed and delivered, these tribes, respectively, took the implied right to dispose of these lands to and for the benefit of the individual members of each tribe. This right inhered in the nature of the grants, was inseperable from them, was in all respects consistent with the purposes of the grants, and made the laws, treaties, and pat. ents under which the right originated irrevocable and a part of the grants; so that no other power than that of these Indian tribes could, without their consent, alter, amend, repeal, or execute the same.

But the United States and the several tribes of Indians had a wise, definite, and benevolent policy in the grant of these lands, which was declared in the most solemn and explicit form, and was often reiterated in those treaties, in the laws, and in the assurances made to the Indians by the President of the United States and by subordinate executive officers. That policy was to secure to the Indians a country in which they could grow up into a civilized, self-governing, prosperous, and Christian people, through laws to be enacted by their tribal legislatures and adjudged and enforced by their tribal authority.

In almost every conceivable form of expression, in treaties, laws, and Executive declarations, this great object was avowed. It was secured by the positive guaranty that these Indian tribes should never be included in the limits of any existing State or Territory, or brought under their jurisdiction, and the further guaranty that no Territorial government should be established over their country without the consent of the tribes, respectively.

This last guaranty, as it did not admit these tribes as States into the Union, may have been a pledge in excess of the constitutional powers of the United States, but the purpose of these agreements, while the same remain capable of being substantially accomplished, rests upon the conscience and good faith of the people with undeniable weight and compels us to find some means, at least, by which the right to their country and their land, and to complete jurisdiction over its disposal to the Indians, shall be secured without any diminution.

The interconrse laws of the United States, which were designed to benefit the Indians and also to preserve peace and regulate trade, were mentioned in these treaties as a means reserved to the United States by which the Indians should have the exclusive occupancy of their country secured to them against unlawful intrusion. Then, over all concerned in these engagements, and for the protection, guidance, and restraint of all alike, the Constitation of the United States was solemnly declared, in these treaties, to be supreme.

Stronger agreements and declarations than these could not have been made, and they were supported not only by the plighted faith of the United States in every department, but they were founded upon the cession by the Indians of areas of country held by them east of the Mississippi River, the iitle to which had been confirmed to them by the Supreme Court of the United States. The history of the rights of these several tribes east of the Mississippi River was not precisely 
the same in each case, but they were substantially the same and were covered by the statements made by Chief-Justice Marshall, in delivering the opinion of the Supreme Court, in the case of Worcester $v$. Georgia (6 Peters, 515).

The facts of history, found and declared by the Supreme Court as the basis of their opinion in that case, with the accompanying comments and decisions as to their meaning and effect, are thus made authentic and should be held as being conclusive by the people of the United States. That statement relates particularly to the Cherokee tribe of Indians, and brings their political history down to the year 1832. Again, the Supreme Court, in the case of Holden $v$. Joy (17 Wallace, 211), takes up the political history of that tribe and continues it until after their migration to the country sold them by the United States, west of the Mississippi, and down to the supplemental treaty of April 27, 1868.

Extracts from the opinions in those cases are appended to this report, as Appendix No. 1, as presenting in authentic form the undisputed facts and the law of their interpretation touching the political history of the five civilized tribes.

The dealings with each of these tribes by the United States has been substantially the same, and, since their location upon their tribal lands, the progress they have made in civilization, Christianity, and self-government has also been substantially the same.

In the treaty of Hopewell, in 1785, it was stipulated-

That the Indians may have full confidence in the justice of the United States reepecting their interests, they shall have a right to send a deputy of their choice, whenever they think fit, to Congress.

Mr. Justice Washington, in his opinion in Worcester $v$. Georgia, says:

In a letter addressed by Mr. Jefferson to the Cherokees, dated the 9th January, 1809 , he recommends them to adopt a regular government, that crimes might be punished and property protected. He points out the mode by which a conncil might be shosen, who should have the power to enact laws; and he also recommended the ppointment of judicial and execntive agents through whom the laws might be enforced. The agent of the Government, who resided among them, was recommended to be associated with their conncil that he might give the necessary advice on all subjects relating to their governmeht. In the treaty of 1817 the Cherokees were encouraged to adopt a regular form of government. By a treaty held at Washington on the 27th of February, 1819, a reservation of land is made by the Cherokees for a school fund, which was to be surveyed and sold by the United States for that purpose.

When the case of Worcester $v$. Georgia was decided the Cherokees in Georgia, within the boundaries of a sovereign State, comprised "The Cherokee Nation," which, the court said:

Is a distinct community, occupying its own territory with boundaries accurately deseribed, in which the laws of Georgia can have no force, and which the citizens of Georgia have no right to enter but with the assent of the Cherokees themselves, or in conformity with treaties and acts of Congress.

The Constitution of the United States describes Indian nations as "Indian tribes." Whether they are dependent nations or states does not affect the relation they hold to the United States as recognized local governments. As "tribes" they are governments with whom the United States can, by agreement, regulate commerce and intercourse. ChiefJustice Marshall says, for the court, in the case cited:

The sixth and seventh articles (of the treaty of Hopewell) stipulate for the punishment of citizens of either country who may commit offenses on or against the citiizens of the other. The only inference to be drawn from them is that the United States considered the Cherokees as a nation. 
After the many conflicts and disturbances between these five tribes and the people of Florida, Georgia, Alabama, and Mississippi, where they resided, the Indians sought refuge, repose, security, and the safety of their race, degraded by the laws of those States, in some respects, to a level with slaves, and perishing rapidly in contact with the vices of the dominant race, by removal to the wilderness west of the Mississippi.

- In this they were encouraged by Congress and every department of the Government. The plan inaugurated by President Washington, and supported with great earnestness by all the earlier Presidents, bo came a settled policy of the Government, not merely as to those tribes but, finally, as to all the friendly tribes of the West. No other plan o. colonization was ever adopted by the United States that was so highly approved or was so confidently relied upon for the elevation of the Indian tribes into self-governing bodies of law-abiding people, and nothing has been so effectual in developing the fitness of the Indian race for the highest civilization and to prove that they have capacity for government in a land of laws as the policy thus established.

To show the action of the Government of the United States in this direction, and to set forth the dealings between the Indians and the United States in respect of the lands of the former, your committee append quotations from the laws, treaties, decisions of courts, declarations of executive officers, and discussions by the Attorneys-General, and by cominittees of the two Houses of Congress, that give the history of these proceedings in chronological order. It will be seen, on examination, that in every act aud declaration of the Government respecting their lands, which constitute the wealth, substantially, of the five civilized. tribes, the right of each tribe, or nation, or Indian government to make laws through their own legislative bodies has been constantly recog. nized, admitted, and acted upon by the United States.

In each of these tribal governments the laws are written; they are enacted by bodies chosen by the ballot in the hands of the people. They have courts of record, regularly and very thoroughly organized, with gradations of power, and the right of appeal to a supreme court, whose decisions are entered of record and are fimal.

The range of the jurisdiction of these courts is much the same with the powers of the courts of the greater number of the States, and includes all civil and criminal jurisdiction that does not belong exclusively to the courts of the United States.

The cases that include Federal questions, arising in the tribal courts, relate almost entirely to the rights that concern the ownership and occupancy of lands, and to questions of Indian citizenship. But when decisions of such questions are made by tribal courts and are found to be contrary to those inade in the United States courts in that country, a practical conflict of power is set on foot that may lead to serious distress and wrong. The decision in the United States courts, although it can not be mandatory on the tribal court, virtually destroys its authority and breaks down the moral and actual influence of the Indian courts in their rightful jurisdiction in the decision of cases between Indian citizens.

These evils are liable to be increased to an extent that will destroy the authority of the tribal courts. They are greatly increased and aggravated by the presence of a very large noncitizen population, some of whom were employed by Indians as laborers, and others who are lawless intruders and refugees from the States and Territories. This noncitizen population, over whom the tribal courts are alleged to have 
no jurisdiction, even for punishment of crime, is more numerous than the Indian population of the several tribes and is rapidly increasing, so that lawlessness is rather the rule than the exception, and the illegal occupancy of lands held by the tribes and the accumulation of great bodies of land in the occupancy of a few people is growing into a serious evil and threat against the power of the tribal laws to secure justice.

The general law of each of these Indian nations retains the title to all lands in the tribe, and permits the occupancy of them by Indians for agricultural and other purposes free of rent and exempt from taxation; so that the title in most cases, if not in all, is still held by the tribes directly under the treaties of the United States with the tribes, and under patents issued under our laws. A Federal question is thus found in almost every case between Indians in which the use, occupancy, or ownership of lands is involved.

For more than a half century the Indian tribal courts have been hearing and deciding such controversies, and the questions are now presented whether their decisions are void, or, if they are erroneous, whether they can be corrected by the Supreme Court of the United States on writs of error to the tribal courts.

No power except that of Congress can prevent the Supreme Court of the United States from reaching these cases and deciding them, in virtue of the supreme appellate power conferred on that court in the Constitution. Congress can refuse to permit the issue of writs of error to the tribal courts, and thus prevent the exercise of this constitutional power and thus deny to Indians this great right.

Congress has accorded this right to litigants in the State and Territorial courts and in the courts of the District of Columbia. They have granted this right to persons who were unlawfully restrained of their liberty under the judgments of courts-martial, and also by the unlawful acts of persons claiming executive authority to imprison them. In all such cases the jurisdiction of the Supreme Court is complete when the right claimed or the power exerted is alleged to arise under a treaty or under the Constitution or the laws of the United States and involves a construction thereof. (Cohens $v$. Virginia, 6 Wheaton, p. 378.) The jurisdiction depends only upon the nature of the case, and may be exercised without any reference to the nature or the location of the court in which the controversy is found.

If Congress provides that the Supreme Court may send a writ of error to a court or tribunal, the Constitution supplies the power to remove the record into the Supreme Court, and make an end of the case by a final judgment. It is a denial of justice for Congress to refuse to enable the Supreme Court of the United States to exercise its appellate powers to correct the judgment of a court rendered in disregard of the Constitution, laws, or treaties of the United States. In the case of the five civilized tribes this injustice seems to be open to censure for wantonness, when our treaties expressly secure to them the benefits and protection of the Constitution of the United States for all their rights of property, the security of their persons, their liberties, and their political and religious rights.

There are but two limitations by which the appellate power of the Supreme Court is prevented from extending. The first is, the nature of the question to be dealt with; the second is, the consent of Congress that a writ of error shall issue to a certain court. A question arose, early in our history, whether the sovereignty of a State created a third limitation upon the appellate jurisdiction of the Supreme Court so as 
to prohibit a writ of error from issuing to a State court. When this supposed obstruction was swept away the only test of jurisdiction remaining is the nature of the question, and the only permission required for its exercise is the consent of Congress.

Some question has been made whether it is not better to place these tribal courts under the revisory power or appellate supervision of the United States courts located in the Indian country. The tribal courts are not United States courts in any respect. They are not created by United States laws nor supplied with United States judges, juries, or officers. They are not supported by the United States and have no power to administer United States laws. It would not be a greater solecism to say that their legislatures are law-making bodies of the United States or that Congress could repeal their statutes. Such conjectures ignore every treaty agreement we have made with these tribes as to their right to make and enforce laws for their own government.

So the United States courts in the Indian country can not exercise control over the tribal courts as inferior jurisdictions created by the United States.

If the appellate power is vested, subject to the regulation of Congress in every United States court, it is a policy now so settled that it will never be violated that no appeal, in any case, can be taken from any State court to any inferior Federal court.

If such a thing may be done by authority of Congress in the case of these tribal courts, the experiment is unnecessary and would lead to delay and protracted litigation, as compared with that which would occur on the removal of a cause or record of a tribal court directly into the Supreme Court by writ of error.

It is scarcely doubtful, also, that to give such revisory or appellate jurisdiction over the tribal courts to the United States courts located in the Indian country would violate the spirit and the terms of our treaties with those Indians. If such revisory power should be confined to cases that involved Federal questions the result would be merely to retard the final decision by the Supreme Court, for no useful purpose. If such revisory power should be extended to all cases in the tribal courts there would be an end to those stipulations of the treaties that remove these Indians from the power of other governments in which they have no voice. That would be a fatal blow at all their efforts at civilization through local self-government.

In several cases the Supreme Court has declared that these tribes are "nations;" not foreign nations, but domestic, dependent nations; nations that are called "tribes" in the Constitution, with whom the United States may enter into treaties and commercial regulations. Without attempting to derive the powers of the tribes through the signification of any title used to describe them, the declarations are decided, ample, and uniform that under our treaties and laws these tribes have all the powers to make and enforce laws and adjudicate matters of right that are needed for the complete government of the people composing the tribes.

We have for more than half a century recognized their full power to dispose of life, liberty, and property among their own peopleand under their own laws. To revoke all this now, by saying that their courts could not render a valid judgment to which a writ of error would lie, would be to admit our participation in cruel acts of deception towards a people over whom we assume a paternal guardianship and dominion.

If we had made the provision for a writ of error fifty years ago that is embodied in this bill, the Indians rould have had the guidance and 
protection of the great tribunal upon which our people rely as the final arbiter of all questions that concern their personal rights and liberties, and, like our people, they would have been able to establish their chiefest interests and prosperity upon the solid basis of selcure titles to their lands.

This, above everything else, has caused the Indians to halt while approaching the shelter of the secure and invulnerable powers of statehood in the American Union.

They have feared that Congress would claim and usurp the power to destroy their land titles as fixed by their awn laws, and have not seen how they could find protection under the appellate jurisdiction of the Supreme Court of the United States, in which they have always found that justice has been rendered them without denial or delay.

No power has been, or ever will be, able to shut them out from the protecting care of the appellate jurisdiction of the Supreme Court of the United States. Because the tribal governments are not States of the American Union within the meaning of the Constitution they were denied the right of resort to the original jurisdiction of the Supreme Court in the case of The Cherokee Nation $v$. Georgia (5 Peters, 1).

And Congress has hitherto withheld from their people the right of direct resort to the appellate jurisdiction of that court. Still, the questions that concern their most vital interests have been considered and decided, in collateral proceedings, in causes in which neither Indians nor their tribal governments are parties and in which they have had no right to appear and be heard. The cases of Holden $v$. Joy (17 Wall., 237), United States $v$. Cook (19 Wall., 593), United States $v .43$ Gallons, etc. (93 U. S., 193), Georgia $v$. Stanton (6 Wall., 73), Scott $v$. Jones (5 How., 374), Cherokee Tobacco (11 Wall., 619), and other cases, serve to illustrate the utter helplessness of a people who must submit to the disposal of their rights in courts where they are denied the privilege of appearing as parties to the proceedings.

In the present state of legislation by Congress, a supreme court of one of the tribal governments can deny to an Indian a right in lands, or any other right secured to him by the Constitution and laws of the United States, or by treaty, and he has no alternative but to submit to the wrong.

Nc Indian courts having these great powers entrusted to them, should be left beyond the reach of the mandate of the Supreme Court of the United States, to compel them to recognize and enforce rights arising under the Constitution and laws of the United States, and the treaties to which their tribes are parties.

The writ of error provided for in this bill is a more direct and speedy remedy than any that exists under any law for the trial of cases in the Cinited States courts. This is an essential matter in the administration of justice in respect of land titles, and the power of disposition, as to tribal lands, given to the legislatures of the respective nations. Such questions, left open now, when lands are in such pressing demand, are too obviously dangerous to the peace of the Indian country to admit of any hesitancy in granting a remedy for their final and satisfactory settlement.

A still higher consideration should move Congress to open a direct channel of communication between the tribal courts of last resort and the Supreme Eurt of the United States. The direct recognition of the legal existence and powers of the tribal courts would give to them a 
dignity and authority that would much increase their value among the people in that country as the dispensers of justice according to law.

The Indian tribes would then realize that, while they have power to make and execute laws respecting their own people in their own country, they are not "a law unto themselves," but belong to a country where all laws must grow out of the legitimate powers of the legislators, conformably to the Constitution of the United States.

The exercise of such jurisdiction under the control of the Suprem Court of the United States would repress the notion of national inde pendence that has misled eso many Indians and made them a prey, through their vain aspirations for supreme power, to the evil machina. tions of designing persons.

Congress also needs the guidance of the Supreme Court in its legis. lation about those delicate and involved questions. that arise out of our treaties with these five tribes, and about their peculiar land laws, that are so different from our system of lands owned in severalty. Such questions are judicial in their character, and rights are always endangered when they stand in the way of questions that are political in their character, and are urged by those who are clamorous for personal advantages, or are excited in the alleged promotion of the general welfare.

Under such circumstances Indian rights sometimes require high judicial protection.

But, above all, it is due to our own history and to the pledges made to these people that the Indians should feel that the great tribunal that has so far protected them from serious wrong will have the final decision of the vexed questions that are arising on all sides as to the power of their tribes to make laws for the disposal of their only remaining patrimony in the country of which they were once the sovereign rulers and owners. 


\section{APPENDIX 1.}

HOLDEN จ. JOY.

Rixtract from opinion of the court, Storey, J.]

DeCtember, 1872.

Disturbances, and in some instances collisions, of a threatening character occurred between the Cherokee Nation of Indians and certain citizens of the States or Territories in which they resided, in consequence of which the United States and the Cherokee Nation became anxious to make some arrangement whereby the difficulties which had arisen by the residence of the Indians within the settled parts of the United States, under the jurisdiction and laws of the States or Territorial governments, might be terminated and adjusted. Measures of various kinds had been devised and tried without effectually accomplishing the object, as will be seen by reference to some of the early treaties with that nation and the acts of Congress upon the subject. (7 Stat. L., 311; Ib., 414.)

Treaties of the kind were conclnded with that nation of Indians on the 6 th of May, 1828 , and on the 14th of February, 1833, in both of whicb the United States agreed to possess the Cherokees of $7,000,000$ acres of land west of the Mississippi River, bounded as therein described, and to guarantee it to them forever, upon the terms and conditions therein stipulated and agreed. Enough appears in those treaties to show that it was the policy of the United States to induce the Indians of that nation, resident in any of the States or organized Territories of the United States, to surrender their lands and possessions to the United States and emigrate and settle in the territory provided for them in those treaties. Sufficient is known, as matter of history, to justify the remark that those measures, as well as some of like kind of an earlier date, were unsuccessful, and that the difficulties continued and became more autl more embarrassing. (The Cherokee Nation v. Georgia, 5 Peters, 15; Worcester v. Georgia, 6 Id., 515.)

Prior measures laving failed to accomplish the object of quieting the disturbances or removing the differities, the United States, on the 29th of December, 1835, concluded a new treaty with the Cheroke Nation with a view to reunite their people in one body and to secure to them a permanent home for themselves and their posterity in the conntry selected for that purpose without the territorial limits of the State sovereignties, und where they could establish and enjoy a government of their choice, aud perpetuate such a state of society as might be consonant with their views, habits, and conditions. (7 Stat. $\mathbb{L}, 479$.)

By the first article of the treaty the Cheroke Nation "cede, relinquish, and convey to the United States all the lands owned, claimed, or possessed by them east of the Mississippı River," and released all their claims for spoliations of every kind, for and in consideration of the sum of $\$ ;, 000,600$, to be expended, paid, and invested in the manner stipulated and agreed upou in other articles of the treaty.

Reference is made in the secund article of the treaty to the respective articles of the two before-mentioned treaties, in which the United States agreed to possess the Cherokees of 7,000,000 acres of land, situated and bounded as therein described, and guaranteed it to them forever upon the terms and conditions therein stipulated and agreed. Apprehension, it seems, was felt by the Cherokees that the cession contained in those treaties, aud confirmed in the new treaty, did not contaiu in sufticient quantity of land for the acconmodation of the whole nation on their semoval, and in view of that fact the United States, in consideration of $\$ 500,000$, rovenauted and agreel to convey to the said Indians and their descendants, by parent in fee simple, a certain tract of land, situated and bounded as therein described, estimated to ci vtain 800,000 acres of land, ever afterwards known as the Cherokee neutral lands, and it is adnitted in the bill of complaint that it includes the tract in controversy.

Authority was conferred upon the President by the first section of the act of the 28 th of May, 1830, to cause so much of any territory belonging to the United States, west of the Mississippi, not included in any State or organized Territory, and to which the Indiantitle had been extinguished, "as he may judge necessary," to be divided into a suitable number of districts, for the reception of such tribes or natious 
of Indians as may choose to excluange the lands where they, now reside and to remove there, and to cause each of said districts to be so described by natural or artificial boundaries as to be easily cistinguishel from every other.

Power is also conferred upon the President by the second section of the act to exchange any or all of such districts with an tribe or nation of Indians residing within the limits of any of the States or Territories, for the whole or any portion of the territory claimed and occupied by snch tribe or nation, within the bounds of any one or more of the States or Territories, sulject fo certain conditions therein prescribed. Section 3 provides that in making snch excbunges the President may solennly assure the tribe or nation that the United States will forever secure and guarantee to them and their heirs and successors the comntry so exclianged with them, and that, if they prefer it, the United States will cause a parent or grant to be made and executed to them for the same, provided that such lands shall revirt to the United States if the Indians become extinct or abandon the territory.

Much reason exists to smppose that Congress in framing those provisions had in view the stipulations of the treaty concluded two years earlier, and it is equally probab'e that the Presideut and Senate in negotiating und conclnding the two treaties of later date were largely governed by the several provisions in that act of Congress, but they were not contralled by these enactwente, as is evident from the fact that the latter of the two contains many stipulations differing widely from the provisious of that act, as, for example, the United States, in the supplemental article enlarging the quantity of land set apart for the accommodation of the nation, expressly covenant and agree to convey the additional tract to the said Indians and their descendants by patent, in fee simple title, and the article does not contain such provision as that contaiued in the third section of the act of Congress, that the iand shall revert to the United States if the Indians become extinct or abandon the territory. ( 4 Stat. at Large, $412 ; 7 I d ., 480$.)

An attempt is uad $\theta$ in argunent to show that the last-named treaty was negotiated ly force of the act of Congress to provide for an excliange of lands with the Indians, but it is clear that the proposition can not be sustained, as the treaty differs widely in many respects frow the provisions of that act of Congress. Doubtless the intent and purpase were tlie savie, to quiet the disturbances and to induce the Indians remaining in the States and Territories to emigrate and settle in the district of country set apart for them without the limits of the several states and organized Territories; but the treaty, thongh conclnder to promote the same object as the act of Congress, adopts very different iustrumenralities. It is a treaty to confirm to the Indians the possession of the 7,000.000 acres of land previously granted to the nation and to purchase their lands eant of the Mississippi River for the sum of $\$ 5,000,000$, to be expended, paid, and invested in the manner therein stipulated and provided.

Such prior grant of land was made or defined under the two treaties before mentioned to secure a new home for the Indians withont the limits of tbe several states and Territories, and to induce the Indians still residing within those limits to einigrate and settle in the country long before set apart for that purpose. Large numbers of the Cherokees emigrated and settled there under the treaty of the $8 \mathrm{th}$ of July, 1817, and measures of various kinds had been adopted, at later periods, to induce the residue of the nation to follow those who had accepted the proffered protection, but without much success. (7 Id., 156.)

Even treaties proved jueffectual, as one after another failed to accomplish the desired end. They would not enigrate without compensation for their improvements, and many were reluctant to accept any of the terms proposed, upon the ground that the quantity of land set apart for the accommodation of the whole nation was not sufficient for the purpose. Twice the United States offered the 7,000,000 acres of land, with other inducements, but the terms, though formally accepted, did not have the effect to accomplish the end. Experience showed that better terms were required and the Government agreed to purchase their lands for the consideration named in the treaty and to convey to the Indians in fee simple title the additional tract of 800,000 acres for $\$ 500,000$, to be deducted from the consideration stipulated to be paid for the purchase of their lands.

Other important stipulations are contained in the treaty, among which are the following: (1) That the United States agree tlat the lands ceded shall all be iveluded in one patent, executed by the Plesidient, to the Cherokes Nation, according to tho provision of the before-mentioned act of Congress. (2) That the United States agree to extinguish, for the benefit of the Cherokees, the titles to the reservations within their country made in the Osage treaty to certain half-breeds, and for that purpose the United States agree to pay to the persons to whom the titles belong the sum of $\$ 15,000$, accorcling to the schedule accompanying the treaty. (3) That the United States shall pay the American Board of Commiswioners for Foreigu Missions for the improrements they have ou the ceded country the sums at which the same shall be appraised, and that the money allowed for the improvements shall be expended in schools among the Osages, and for improving theix condition. (4) That the land 
ceded to the Cherokee Nation shall, in no future time, be included, without their consent, within the territorial limits or jurisdiction of any State or Territory. (5) That the United States agree to protect the Cherokee Nation from domestic strifes and foreign enemies and against intestine wars between the several tribes. (6) That the United States agree to remove the Cherokees to their new homes and to subsist them for one year after their arrival. (7) That the United States shall liquidate claims for reservations and pay the sums awarded to the claimants, and many other stipulations which were of great valne and highly beneficial to the Cherokee Nation.

Valid treaties were made by the President and Senate during that period with the Cherokee Nation, as appears by the decision of this court in several cases. (United States $v$. Rogers, 4 Howard, 567.) Indeed, treaties have been made by the United States with the Indian tribes ever since the Union was formed, of which numerous examples are to be found in the seventh volume of the public statutes. (Cherokee Nation $v$. Georgia, 5 Peters, 17; Worcester v. Georgia, 6 Id., 543.) Indian tribes are States in a certain sense, though not foreign states, or States of the United States, within the meaning of the second section of the third article of the Constitution, which extends the judicial power to controversies between two or more States, between a State and citizens of another State, between citizens of different States, and between a State or the citizens thereof and foreign states, citizens, or subjects. They are not States within the meaning of any one of those clauses of the Constitution, and yet in a certain domestic sense, and for certain mnnicipal purposes, they are States, and have been uniformly so treated since the settlement of our country and throughout its history, and numerous treaties made with them recoguize them as a people capable of maintaining the relations of peace and war, of being responsible, in their political character, for any violation of their engageinents, or for any aggression committed on the citizens of the United States by any individual of their community. Laws have been enacted by Congress in the spirit of those treaties, and the acts of our Government, both in the executive and legislative departments, plainly recognize such tribes or nations as States, and the courts of the United States are bound by those acts. (Doe v. Braden, 16 Howard, 635 ; Fellows v. Blacksmith, 19 Id., 372; Garcia v. Lee, 12 Peters, 519.)

Express power is given to the President, by and with the advice and consent of the Senate, to make treaties, provided two thirds of the Senators present concur; and inasmuch as the power is given in general terms without any description of the oljects intended to be embraced withiv its scope, it must be assumed that the framers of the Constitution intended that it should extend to all those objects which in the intercourse of nations had usually been regarded as the proper subjects of negotiation and treaty, if not inconsistent with the nature of our Government and the relation between the States and the United States. (Holmes v. Jennison et al., 14 Peters, 569 ; 1 Kent, 166 ; ¿2 Story on the Constitution, sec. 1508; 7 Hamilton's Works, 501; Duer's Jurisprudence, 229.)

Beyond doubt the Cherokees were the owners and oceupants of the territory where they resided before the first approach of civilized man to the western continent, deriving their title, as they claimed, from the Great Spirit, to whom the whole earth belongs, and they were unquestionably the sole and exclusive masters of the territory, and claimed the right to govern themselves by their own laws, usages, and customs. Guided by nautical skill, enterprising navigators were conducted to the New World. They found it, says Marshajl, C. J., in possession of a people who had made small progress in agriculture or manufactures, and whose general employment was war, hunting, and fishing. Expeditions were fitted out by all the great maritime powers of the Uld World, and they visited nany parts of the newly discovered cuntinent, and each made claim to such part of the country as they visited. Disputes arose and conflicts were in prospect, which made it'necessary to establish some principle which all would acknowledge, and which should decide their respective rights in case of conflicting pretensions, Influenced by these considerations they agreed that discovery should determine the right, that discovery should give title to the government by whose subjects or by whose authority it was made agaiust all other governments, and that the title so acquired migbt be cansummated by possession. (Johnson v. McIntosh, 8 Wheat., 573.) As a necessary consequence the principle established gave to the nation making the discovery the sole right of acquiring the soil and of making settiements on it. Obviously this principle regulated the right conceded by discovery among the discoverers, but it could not affect the rights of those already in possession, either as aboriginal occupants or as occupants by virtue of a more ancient disoovery. It gave the exclusive right to purchase, but did not fourd that right on a denial of the right of the possessor to sell. Colonies were planted by Great Britain, and the United States, by virtue of the revolution and the treaty of peace, succerled to the extent therein provided to all the claims of that Government, botb political and territorial. Throughout the Indians, as tribes or nations, have been considered as distinct, independent communities, retaining their original natural rights as the undisputed possessors of the soil from time immemo. 
rial, subject to the conditions imposea by the discoverers of the continent, which excluded them from intercourse with any other government than that of the first discoverer of the particular section claimed. They could sell to the government of the discoverer, but they could not sell to any other governments or their subjects, as the govermment of the discoverer acquired by virtue of tbeir discovery the exclusive preëmption right to purchase and the right to exclude the subjects of all other governments, and even their own, from acquiring title to the lands.

Enongh has already been remarked to show that the lands conveyed to the United States by the treaty were held by the Cherokees under their original title, acquired by immemorial possession, commencing ages before the New World was known to civilized man. Unmistakably their title was absolute, subject only to the preëmption right of purchase acquired by the United States as the successors of Great Britain, and the right also on their part as such successors of the discoverer to prohibit the sale of the land to any other governments or their subjects, and to exclude all other go,veruments from any interference in their affairs. (Mitchel et al. v. United States, 9 Peters, 748.) Evidently, therefore, the Cherokees were competent to make the sale to the United States, and to purchase the lands agreed to be conveyed to them by the second article of the treaty. Both parties concerie that the title of the United States to the tract known as the Cherokee neutral lands was perfect and complete, and that the tract includes the land in controversy. Title to that tract was acquired by the United States as a part of the Louisiana purchase from the French Repablic. By the treaty between the United States and the French Republic of April 30, 1803 , the chief executive officer of that Republic ceded the said territory to the United States, with all its rights and appurtenances, forever. (8 Stat. L., 200.) When the President took pose ession of the territory the absolute fee-simple title and right of sovereignty and jurisdiction became vested in the United States as the successor of the original discoverer, subject only to the Indian titie and right of occupancy as universally acknowledged by all the departments of our government throughout our history. All agree that this land then, and for many years thereafter, was occupied by the Osage Indians. On the 2d of June, 1825, the Osage tribes, by the treaty of that date, ceded to the United States all their right, title, interest, and claims to the lands lying * * * west of the State of Missouri, with such reservations and for such oonsiderations as are therein specified, which, it is cenceded, extinguished forever the title of the Osage Indians to the neutral lands. (7 Id., 240.)

Prior to the treaty of the $8 \mathrm{th}$ of July, 1817, the Cherokees resided east of the river Mississippi. Pursuant to that treaty thoy were divided into two parties, one elect. ing to remain east of the Mississippi and the other electing to emigrate and settle west of it, and it appears that the latter made choice of the conutry on the Arkansas and White rivers, and that they settled there upon the lands of the United States described in the treaty. (Ib., 157.)

*

*

*

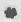

\section{WORCESTER v. THE STATE OF GEORGIA. 6 P.}

[Extract from the opinion of Marshall, C. J,]

This was the settled state of things when the war of our Revolution commenced. The influence of our enemy was established; her resources enabled her to keep up that influence; and the colonists had much cause for the apprehension that the Indian nations would, as the allies of Great Britain, add their arms to hers. This, as was to be expected, became an object of great solicitude to Congress. Far from advancing a claiu to tlieir lands, or asserting any right of dominiou over them, Congress resolved "that the securing and preserving the friendship of the Indian nations appears to be a subject of the utmest moment to these colouies."

The early journals of Congress exhibit the most anxious desire to conciliate the Indian nations. Three Indian departments were established, and commissioners appointed in each, "to treat with the Indians in their respective departments, in the name and on the behalf of the united colonies, in order to preserve peace and friend. ship with the said Indians, and to prevent their taking any part in the present commotions."

The most strenuous exertions were made to procure those supplies on which Indian friendships were supposed to depend; and everything which wight excite hostility was avoided. 13.)

The first treaty was made with the Delawares, in September, 1778. (7 Stat. L.,

The language of equality in which it is drawn evinces the temper with which the negotiation was undertaken, aud the opinion which then prevailed in the United States, 
"1. That all offenses or acts of hostilities, by one or either of the contracting parties against the other, be mutually forgiven and buried in the depth of oblivion, never more to be had in remembrance.

"2. That a perpetual peace and friendship shall, from benceforth, take place and subsist between the contracting parties aforesuid through all succeeding generations, and if either of the parties are engaged in a just and necessary war with any other nation or vations, that then each shall assist the other in due proportion to their abilities, till their enemies are brought to reasonable terms of accommodation," etc.

3. The third article stipulates, among other things, a free passage for the American troops through the Delaware Nation, and engages thal they shall be furnished with provisions and other necessaries at their value.

"For the better security of the peace and friendship now entered into by the contracting parties against all infractions of the same by the citizens of either party to the prejndice of the other, neither party shall proceed to the infliction of punishments on the citizens of the other otherwise than by sectaring the offender or offenders, by imprisonment or any other competent means, till a fair and isnpartial trial can be had by judge or juries of both parties, as near as can be to the laws, customs, and usages of the contracting parties and natural justice," etc.

5. The fifth artiole regulates the trade between the contracting parties in a manner entirely equal.

6. The aixth article is entitled to peculiar attention, as it contains a disclaimer of designs which were, at that time, ascribed to the United States by their enemies, and from the imputation of which Congress was then peculiarly anxious to free the Government. It is in these words: "Whereas the enemies of the United States have endeavored, by every artifice in their power, to possess the Indians in general with an opinion that it is thedesign of the States aforesaid to extirpate the Indians and take possession of their country; to obviate such false suggestion, the United States do engage to guarantee to the aforesaid nation of Delawares and their heirs all their territorial rights in the fullest and most ample manner, as it hath been bonnded by former treaties, as long as the said Delaware Nation shill abide by and hold fast the chain of friendship now entered into."

The parties further agree that other tribes, friendly to the interest of the United States, may be invited to form a State, whereof the Delaware nation shall be the heads, and have a representation in Congress.

This treaty, in its language and in its provisions, is formed, as'near as may be, on the model treaties between the crowned heads of Europe.

The sixth article shows how Congress then treated the injurious calumny of cherishing designs unfriendly to the political and civil rights of the Indians.

During the war of the Revolution, the Cherokees took part with the British. After its termination, the United States, though des rous of peace, did not feel its necessity so strongly as while the war continued. Their political situation being changed, they wight very well think it udvisable to assume a higher tone, and to impress on the Cherokees the same respeet for Congress which was before felt for the King of Great Britain. This may account for the language of the treaty of Hopewell. (7 Stat. at Large, 18.) There is the more reason for supposing that the Cherokee chiets were not very oritical judges of the language, from the fact that every one makes his mark; no chief was capable of signing his name. It is probable the treaty was interpreted to them.

The treaty is introduced with the declaration, that "the commissioners plenipotentiary of the United States give peace to all the Cherokees, and receive them into the favor and protection of the United States of Amerioa, on the following conditions."

When the United States gave peace, did they not also receive it Were not both parties desirous of it 1 If we consult the history of the day, does it not inform us that the United States were at least as anxious to obtain it as the Cherokees? We may ask, further, did the Cherokees come to the seat of the American Government to solicit peace; or, did the American commissioners go to them to obtain it 9 The treaty was made at Hopewell, not at New York. The word " give," then, has no real importance attached to it.

The first and second articles stipulate for the mutual restoration of prisoners, and are of course equal.

The third article acknowledges the Cherokees to be under the protection of the United States of America, and of no other power.

This stipulation is found in Indian treaties, generally. It was introduced into their treaties with Great Britain, and may probably be found in those with other Enropean powers. Its origin nay be traced to the nature of their connection with thore powers; and its true meaning is discerned in their relative situation.

The general law of European sovereigns, respecting their claims in America, limited the intercourse of Indians, in a great degree, to the partioular potentate whose ultimate right of domain was acknowledged by the others. This was the general state 
of thiugs in time of peace. It was sometimes changed in war. The consequence was, that their supplies were derived chiefly from that nation, and their trade confined to 1t. Goods, indispensable to their comfort, in the shape of presents, were received. from the same hand. What was of still more importance, the strong hand of government was interposed to restrain the disorderly and licentious from intrusions into their country, from encroakments on their lands, and from those acts of violence which were often attended by reciprocal murder. The Indians perceived in this pro. tection only what was beneficial to themselves, an engagement to punish aggressions on them. It involved, practically, no claim to their lands, no dominion over their persons. It merely bound the nation to the British crown, as a dependent ally, claiming the protection of a powerful friend and neighbor, and receiving the advantages of that protection, without involving a surrender of their national character.

This is the true meaning of the stipulation, and is undoubtedly the sense in which it was made. Neither the British Government nor the Cherokees ever understood it otherwise.

The same stipulation entered into with the United States is undoubtedly to be construed in the same manner. They receive the Cherokee Nation into their favor and protection. The Cherokees acknowledge themselves to be under the protection of the United States, and of no other power. Protection does not imply the destruction of the protected. The manner in which this stipulation was understoad by the American Government is explained by the language and acts of our first President.

The fourth article draws the boundary between the Indians and the citizens of the United States. But in describing this boundary, the term "allotted" and the term " hanting ground" are used.

It is reasonable to suppose that the Indians who could not write, and most probably coald not read, who certainly were not critical judges of our language, should distinguish the word "allotted" from the words "marked out." The actual subject of contract was the dividing line between the two nations, and their attention may very well be supposed to have veen confined to that subject. When, in fact, they were ceding lands to the United States, and describing the extent of their session, it may very well be supposed that they might not understand the term employed, as indicating that instead of granting, they were receiving.lands. If the term would admit of no other signification, which is not conceded, its being misunderstood is so apparent, results so necessarily from the whole transaction, that it must, we think, be taken in the sense in which it was most obviously used.

So with respect to the words "hunting grounds." Hunting was at that time the principal occupation of the Indians, and their land was more used for that purpose than for anv other. It conld not, however, be supposed that any intention existed of restricting the full use of the lands they reserved.

To the United States it coald be a matter of no concern whether their whole territory was devoted to hunting grounds or whether an occasional village and an occasional cornfield interrupted and gave some variety to the scene.

These terms had been used in their treaties with Great Britain and had never bewn misunderstood. They had never been supposed to imply a right in the British Government to take their lands or to interfere with their internal government.

The fifth article withdraws the protection of the United States from any citizen who has settled or shall settle on the lands allotted to the Indians for their hunting grounds, and stipulates that if he shall not remove within six months the Indians may punish him.

The sixth and seventh artioles stipulate for the punishment of the citizens of either country who may commit offenses on or against the citizens of the other. The only inference to be drawn from this is that the United States considered the Cherokees as a nation.

The ninth article is in these words: "For the benefit and comfort of the Indians, and for the prevention of injuries or oppressions on the part of the citizens or Indians, the United States, in Congress assembled, shall have the sole and exclusive right of regulating the trade with the Indians, and managing all their affairs, as they think proper."

To construe the expression, "managing all their affairs," into a surrender of selfgovernment, would be, we think, a perversion of their necessary meaning, and a departure from the construction which has been uniformly put on them. The great subject of the article is the Indian trade. The influence it gave made it desirable that Congress should possess it. The commissioners brought forward the claim with the profession that their motive was " the benefit and comfort of the Indians, and the prevention of injuries or oppressions." This may be true as respects the regulation of their trade and as respects the regulation of all affairs connected with their trade, but can not be true as respects the management of all their affairs. The most important of these are the cession of their lands and secarity against intruders on them. Is it eredible that they should have considered themselves as surrendering to the United States the right to dictate their futare cessions, and the terms on 
Which they shonld be made, or to compel their submission to the violence of disorderly and licentions iutruders It is eqnally inconceivable that they conld have supposed themeelves, by a phrase thus slipped into an article on another and most interesting subject, to have divested themselves of the right of self-government on subjects not convected with trade. Such a measure could not be "for their benefit and comfurt," or for "the prevention of injuries and oppression." Snch a construction would be inconsistent with the spirit of this and of all subsequent treaties, especially of those articles which recognize the right of the Cherokees to declare hostilities and to make war. It would convert a treaty of peace covertly into an act aunihilating the political existence of one of the parties. Had such a result been intended it would have been openly avowed.

This treaty conteins a few terms capable of being used in a sense which could not have been intended at the time, and which is inconsistent with the practical constiruction which has always been pnt on them; but its essential articles treat the Cherokees as a nation capable of maintaining the relations of peace and war, and ascertain the boundaries between them and the United States.

The treaty of Hopewell seems not to have established a solid peace. To accommodate the differences still existing between the State of Georgia and the Cherokee Nation, the treaty of Holston was negotiated in July, 1791 (7 Stats. at Large, 39). The existing Constitution of the United States had been then adopted, and the Govermment, having more intrinsic capacity to enforce its just cla1ms, was, purhaps, less mindful of high-sounding expressions denoting superiority. We hear no more of giving peace to the Cherokees. The mutual desire of establishing permanent peace and friendship and of removing all canses of war is honestly avowed; and, in pursuance of this desire, the first article declares that there shall be perpetual peace and friendship between all the citizens of the United States of America and all the individuals composing the Cherokee Nation.

The second article repeats the important acknowledgment that the Cherokee Nation is under the protection of the United States of America and of no other sovereign whosoever.

The meaning of this has been already explained. The Indian nations were, from their situation, necessarily dependent on some foreign potentate for the supply of their essential wants and for their protection from lawless and injurious intrusions. into their country. That power was naturally termed their protector. They had been arranged under the protection of Great Britain, but the extinguishment of the British power in their neighborhood, and the establishment of that of the United, States in its place, led naturally to the declaration, on the part of the Cherokees, that they were under the protection of the United States and of no other power. Thes assumed the relation with the United States which had before subsisted with. Great Britain.

This relation was that of a nation claiming and receiving the protection of one more powerful, not that of individuals abandoning their national character and submitting as subjects to the laws of a master.

The third article contains a perfectly equal stipulation for the surrender of prisoners.

The fourth article declares that "the boundary between the United States and! the Cherokee Nation shall be as follows: Beginning," etc. We hear no more of "allotments" or of "hunting grounds." A boundary is described between nation and. nation by mutual consent. The national character of each, the ability of each to establish this bonndary, is acknowledged by the other. To preclude forever all disputes, it is agreed that it shall be plainly marked by commissioners to be appointed: by each party; and, in order to extinguish forever all claim of the Cherokees to the ceeded lands, an additional consideration is to be paid by the United States. For this additional consideration the Cherokees release all right to the ceded land forever.

By the fifth article the Cherokees allow the United States a road through their conntry and the navigation of the Tennessee River. The acceptance of these cessious is an acknowledgment of the right of the Cherokees to make or withhold them.

By the sixth article it is agreed on the part of the Cherokees that the United States shall have the sole and exclusive right of regulating their trade. No claim is made to the management of all their affairs. This stipulation has already been explained. The observation may be repeated, that the stivulation is itself an admission of their right to make or refuse it.

By the seventh article the United States solemnly guarantee to the Cherokee Nation all their lands not hereby ceded.

The eighih article relinquishes to the Cherokees any citizens of the United States who may settle on their lauds, and the ninth forbids any citizen of the United States to bunt on their lands, or to enter their conntry without a passport.

The remaining articles are equal aud contain stipulations which could be made only with a nation admitted to be capable of governing itself.

This treaty, thus explicitly recognizing the national character of the Cherokees 
and their right of self-government, thas guaranteeing their lands, assuming the duty of protection, and of course pledging the faith of the United States for that protection, has been frequently renewed and is now in full force.

To the general pleige of protection have been added several specific pledges, deemed valuable by the Indians. Some of these restrain the citizens of the United States from encroachments on the Cheroke country and provide for the punishment of intruders.

From the commencement of our Government, Congress has passed acts to regulath trade and intercourse with the Indians, which treat them as nations, respect theit rights, and manifest a firm purpose to afford that protection which treaties stipulate. All these acts, and especially that of 1802 which is still in force, manifestly consider the several Indian nations as clistinct political communities, having territorial boundaries, within which their authority is exclusive, and having a right to all the lando within those boundaries, which is not only acknowledged, lsut guaranteed by the United States.

In 1819, Congress passed an act (3 Stats. at Large, 516) for promoting those humane dosigns of civilizing the neighboring Indians, whioh had loug been cherished by the Executive. It enacts, "that for the purpose of providing against the further decline and final extinction of the Indian tribes adjoining to the frontier settlements of the United States, and for introducing among them the habits and arts of civilization, the President of the United States shall be, and he is hereby authorized, in every case where he shall judge improvement in the habits and condition of snch Indians practicable, and that the means of instruction can be introduced with their own consent, to employ capable persons of good moral character to instruot them in the mode of agriculture suited to their situation; and for teaching their children in reading, writing, and arithmetic; and for performing such other duties as may be enjoined, according to such instructions and rules as the President may give and prescribe for the regulation of their conduct in the discharge of their duties."

This act avowedly contemplates the preservation of the Indian nations as an object sought by the United States, and proposes to effect this object by civilizing and converting them from hunters into agriculturists. Though the Cherokees had already made considerable progress in this improvement, it can not be doubtei that the general words of the act comprehend them. Their advance in the "habits and arts of civilization" rather encouraged perseverance in the laudable exertions still furcher to meliorate their condition. This act furnishes strong additional evidence of a settled purpose to fix the Indians in their country by giving them security at home.

The treaties and laws of the United States contemplate the Indian Territory as completely separated from that of the States, and provide that all intercourse with them shall be carried on exclusively by the Government of the Union.

Is this the rightful exercise of power or is it usurpation?

While these States were colonies this power, in its utmost extent, was admitted to reside in the Crown. When our revolutionary struggle commenced, Congress was composer of an assemblage of deputies acting under specific powers granted by the legislatures or conventious of the several colonies. It was a great popular movement, not perfectly organized; nor were the respective powers of those who were intrusted with the management of affairs accurately defined. The necessities of our situation produced a general conviction that those measnres which concerned all must be transacted by a body, in which the representatives of all were assembled, and which could command the confidence of all; Congress, therefore, was considered as invested with all the powers of war and peace, and Congress dissolved our connection with the mother country, and declared these united colonies to be indepentent States. Without any written definition of powers they employed diplomatio agents to represent the United States at the several courts of Europe, offered to negotiate treaties with them, and did actually negotiate treaties with France. From the same necessity and on the sane principles, Congress assumed the management of Indian affairs; first in the name of these united colonies, and afterward in the name of the United States. Early attempts were made at negotiation, and to regulate trade with them. These not proving successful, war was carried on nnder the direction and with the forces of the United States; and the efforts to make peace by treaty were earnest and incessant. The Confederation found Congress in the exercise of the same powers of peace and war, in our relations with Indian nations as with those of Europe.

Such was the state of things when the Confederation was adopted. That instrument surrendered the powers of peace and war to Congress, and probibited them to the States, respectivelr, minless a State be actually invaded, "or shall have received certain advice of a resolutinn being formed by some nation of Indians to invadesuch State, and the danger is so imminent as not to armit of delay till the United States in Congress assembled can be consulted." This instrument also gave the United States in Congress assembled the sole and exclusive right of "regulating tbe trade and managing all the affairs with the Indians, not memburs of any of the States; provided that the legislative power of any State within its own limits be not infringed or violated." 
The ambiguous phrases which follow the grant of power to the United States were so construed by the States of North Carolina and Georgia as to annul the power itself. The discontents and confusion resulting from these conflieting claims produced representations to Congress, which were referred to a comnitiee, who made their report in 1787 . The report does not assent to the construction of the two States, but recommends an accommodation, by liberal assertions of territory, or by an adminsion, on their part, of the powers claiued by Congress. The correct exposition of this article is rendered unnecessary by the adoptiou of our existing Constitution. That instrument confers on Congress the powers of war and peice; of making treaties, and of regulating commerce with foreign nations, and among the several States, and with the Indian tribes. These powers comprehend all that is required for the regalation of our intercourse with the Indians. They are not limited by any restrictious on their free actions. The shackles imposed on this power, in the Confederation, are discarded.

The Indian nations had always been considered as distinct, independent, political communities, retaining their original natural rights, as the undisputed possessors of the soil from time immemorial, with the single exception of that imprised by irresistible power, which excluded them from interconrse with any other European potentate than the first discoverer of the coast of the particular region claimed; and this was a restriction which those European potentates imposed on themselves, as well as on the Indians. The very term "natiou," so geverally applied to them, means a "people distinct from otbers." The Constitution, by declaring treaties already made, as well as those to be made, to be the supreme law of the land, has adopted and sanctioned the previous treaties with the Indian nations, and consequently admits their rank among those powers who are capable of making treaties. "The words "treaty" and "nation" are words of our own langnage, selected in our diplomatic and legislative proceedings, by ourselves, having each a detinite and well understood meaning. We have a!pplied them to Indians, as we have applied them to the other nations of the earth. They are applied to all in the the same sense.

Georgia herself has furnished conclusive evidence that her former opinions on this subject concurred with those entertained by her sister States and by the Government of tbe United States. Various acts of her legislature have been cited in the argument, including the contract of cession made in the year 1802, all tenuing to prove her acquiescence in the universal conviction that the Indian nations possessed a full right to the lands they occupied until that right should be extinguished by the United States, with their consent; that their territory was separated from that of any State within whose chartered limits they might reside by a boundary line, estahlished by treaties; that within their boundary they possessed rights with which no State could interfere, and that the whole power of regulating the iutercourse with them was vested in tha United States. A review of these acts on the part of Georgia would occupy too mnch time, and is the less necessary, because they have been acenrately detailed in the argument at the bar. Her uew series of laws, manifesting her abandonment of these opinions, appears to have commenced in December, 1828.

In spposition to this original right, possessed by the undisputed occupants of every country; to this recognition of that right, which is evidenced by our history, in every change through whioh we have passed, is placed the charters granted by the monarch of a distant and distinct region, parcelling ont a territory in possession of others whom he could no remove, and did not attempt to remove, and the cession made of his claims by the treaty of peace.

The actual state of thinge at the time and all history since explain these charters; and the King of Great Britain, at the treaty of peace, could cede only what belonged to his erown. These newly asserted titles can derive no aid from the articles so often repeated in Indian treaties; extending to them first the protection of Great Britain and afterwards that of the United States. These articles are associated with others, recognizing their title to self-government. The very fact of repeated treaties with them recognizes it, and the settled doctrine of the law of nations is, that a weaker power does not surrender its independence-its right to self-government-by associatiug with a stronger and taking its protection. A weak state, in order to provide for its safety, may place itself under the protection of one more powerful without stripping itself of the right of government and ceasing to be a state. Examples of this kind are not wanting in Europe. "Tributary and feudatory states," says Vattel, "do not thereby cease to be sovereign and independent states so long as selfgovernment and sovereign and independeut authority are left in the administration of the state." At the present day more than ove state may be considered as holding its rights of self-government under the guaranty and protection of one or more allies.

The Cheroke Nation, then, is a distinct community, occupying its own territory, with boundaries accurately described, in which the laws of Georgiacan have no force and which the citizens of Greorgia have no right to enter, but with the assent of the Cherokees themselves, or in confornity with treaties and with the acts of Congress. The whole intercourse between the United States and this nation is, by our constitution and laws, vested in the Government of the United States.

S. Rep. $281 \longrightarrow 2$ 


\section{APPENDIX 2}

\section{PRELIMINARY}

[Inatructions to Cherokee Commission. Senate Ix. Doc. No. 78, Fifty-first Congress, first eesalon, pp. 2, 3.]

* * In 1808 the Cherokee Indians lived in the States of North Carolina, Georgia, and Tennessee, and in the autumn of that year two deputations of said Indians, from what were known respectively as the Upper Cherokee towns and the . Lower Cherokee towns, visited Washington. They called upon the President and made the following representations :

The deputies of the upper towns stated the desire of the Cherokees represented by them to engage in the pursuits of agriculture and of civilized life. They stated that it was impracticable to induce the uation at large to do this, and they requested the establishment of a division line between the upper towns and the lower towns. They also stated that by contracting their society within narrow limits they could and would begin the establishment of a regular government operated under fixed lsws.

The deputies of the lower towns expressed their desire to continue to live as hunters, and stated that because of the scarcity of game in their neighborhood they wished to remove west of the Mississippi River to some vacant lands of the United States.

Under date January 9, 1809, the President replied to the deputations, saying that the United States was willing to satisfy the wishes of both.

Those who wished to remain were "assured of our patronage, onr aid, and good neighborhood." Those who wished toremove were'granted permission to send an ex. ploring party to reconnoiter the country on the Arkansas and White rivers, with the understanding that when they should find a tract of country that pleased them, and was not claimed by other Indians, arrangements would be made for an exchange of the country selected for a just portion of their country east of the Mississippi, to a part of which, proportioned to their numbers, the emigrating Indians would, it was held and admitted, have a just right.

Upon this permission the Indians who desired to emigrate explored the country west of the Mississippi and White rivers, settled thereon and sent their agents with full power to execute a treaty relinquishing to the United States all the right, title, and interest to all lands of right to them belonging as a part of the Cherokee Nation.

Accordingly, on July 8, 1817, a treaty was entered into between the United States and the "chiefs, headmen, and warriors of the whole Chorokee Nation " (7 Stat., 156), by which the United States agreed to give to that part of the Cherokee Nation located on the Arkansas and White rivers a tract of land "to commence on the north side of Arkansas River, at the mouth of Point Remove, or Budwell's old place, thence by a straight line northwardly to strike Chatanga Mountain on the hill first above Shields Ferry on White River, running up and between said rivers for complement, the banks of which river to be the line." This land was given for as much land east of the Mississippi, conveyed to the United States by the Cherokee Nation, "acre for acre" as the just proportion due that portion of the nation on the Arkansas, agreeably to their numbers.

Other treaties between the United States and the Cherokees were made as follows:

(1) That of February 27, 1819 (7 Stat., 195), by which the Indians ceded certain lands east of the Mississippi River "in full satisfaction of all claims which the United States have on them, on account of the cession to a part of their nation who have or may hereafter emigrate to the Arkansas; and this treaty is a final adjustmentof that of the eighth of July, eighteen hundred and seventeen."

(2) That of October 24, 1824 (7 Stat., 228), by which the Cherokee Nation made further cessions to the United States of lands lying east of the Mississippi. 
TREATIES AND ACTS OF CONGRESS UNDER WHICH THE CHEROKEE NATION DERIVES TITLE TO ITS PRESENT POSSESSIONS.

[Treaty of Washington, May 6, 1828, 7 Stat., 311.]

Whereas it being the anxious desire of the Government of the United States to secure to the Cherokee Nation of Indians, as well those now living within the limits of the Territory of Arkansas as those of their friends and brothers who reside in States east of the Mississippi, and who may wish to join their brothers of the West, a permanent home, and which shall, under the most solemn guarantee of the United States, be and remain theirs forever-a home that shall never, in all future time, be embarrassed by having extended around it the lines, or placed over it the jurisdiction of a Territory or State, nor be pressed upon by the extension, in any way, of any of the limits of any existing Territory or State; and

Whereas the present location of the Cherokees in Arkansas being unfavorable to their present repose, and tending, as the past demonstrates, to their future degradation and misery; and the Cherokees being anxious to avoid such consequences, and yet not questioning their right to their lands in Arkansar, as secured to them by treaty, and resting also upon the pledges given them by the President of the United States and the Secretary of War of March, 1818, and 8th of Octobor, 1821, in regard to the outlet to the West, and as may be seen on referring to the records of the War Department, still being anxious to secure a permanent home, and to free themselve, and their posterity from an embarrassing connection with the Territory of Arkansas and guard themselves from such connection in future; and

Whereas it being important, not to the Cherokees only, but also to the Choctaws, and in regard also to the question which mas be agitated in the future respecting the location of the latter, as well as the former, within the limits of the Territory or State of Arkansas, as the case niay be, and their removal therefrom; and to avoid the cost which may attend negotiations to rid the Territory or State of Arkansas, whenever it may become a State, of either or both of those tribes, the parties hereto do hereby conclude the following articles, viz:

ART. 2. The United States agree to possess the Cherokees, and to guarantee it to them forever, and that guarantee is hereby solemaly pledged, of seven millions of acres of land, to be bounded as follows, viz: Commencing at that point on Arkansas River where the eastern Choctaw boundary line strikes said river, and running thence with the western line of Arkansas, as defined in the foregoing article, to the southwest corner of Missouri, and thence with the western boundary line of Missouri till it crosses the waters of Neosho, generally called Grand River; thence due west to a point from which a due south course will strike the present northwest corner of Arkansas Territory; thence continning due south, on and with the present western boundary line of the 'Territory to the main branch of Arkansas River; thence down said river to its junction with the Canadian River, and thence up and between the said rivers Arkansas and Canadian, to a point at which a line running north and south from river to river will give the aforesaid seven unillions of acres. In addition to the seven millions of acres thus provided for and bounded, the United States further guarantee to the Cberokee Nation a perpetual outlet west, and a free and uninolested use of all the country lying west of the western boundary of the above-described limits, and as far west as the sovereignty of the United States and their right of soil extend.

ART. 7. The chiefs and headmen of the Cherokee Nation aforesaid, for and in coneideration of the foregoing stipulations and provisions, do hereby agree, in the name and behalf of their nation, to give up, and they do bereby surrender to the United States, and agree to leave the same witbin fourteen months, as hereinbefore stipu. lated, all the lands to which they are entitled in Arkansas, and which were secured to them by the treaty of 8 th January, 1817, and the convention of the 27 th February, 1819.

ART. 8. The Cherokee Nation west of the Mississippi, having by this agreement freed themselves from the harassing and ruinous effects consequent upon a location amidst a white population, and secured to themselves and their posterity, under the solemn sanction of the guarantee of the United States as contained in this agreement, a large extent of unembarrassed country; and that their brothers yet remaining in the States rnay be induced to join them and enjoy the repose and blessings of sach a state in the future, it is further agreed, on the part of the United States, \&ce. (Here follow certaiu provisions for the benetit of such of the Cherokees east of the Mississippi as may desire to remove West.)

(NotE. - This treaty was ratified with the following proviso, expressed in the resolation of the Senate:)

Provided, nevertheless, That the said couvention shall not be so coustrued as to extend the northern boundary of the "perpetual outlet west," provided for and guar- 
anteed in the second article of said convention, north of the thirty-sixth degree of north latitude, or so as to interfere with the lands assigned, or to be assigned, west of the Mississippi River, to the Creek Indians who have emigrated, or who migrate, from the States of Georgia and Alabama, under the provisiuns of any treaty of treaties heretofore concluded between the United States and the Creek tribe of Indians; and provided further, that nothing in the said convention shall be construed to cede or assign to the Cherokees any lands heretofore ceded or assigned to any tribe or tribes of Indians, by any treaty now existing and in force with any such tribe or tribes.

[Act May 28, 1830, 4 Stat., 411.]

Be it enacted by the Senate and House of Representatives of the United States of America in Congress assembled, That it shall and may be lawful for the President of the United States to cause so much of any territory belonging to the United States, west of the river Mississippi, not included in any State or organized Territory, and to which the Indian title has been extinguished, as be may judge necessary, to be divided into a suitable number of districts for the reception of such tribes or nations of Indians as may choose to exchange the lands where they now reside and remove there, and to cause each of said districts to be so described by natural or artiticial marks as to be easily distinguished from every other.

Sric. 2. And be it further enacted, That it shall and may be lawful for the President to exchange any or all of such districts so to be laid off and described with any tribe or nation of Indians now residing within the limits of any of the States or Territories, and with which the United States have existing treaties, for the whole or any part or portion of the Territory claimed and occupied by.such tribe or nation, within the bounds of any one or more of the States or Territories where the land claimed and occupied by the Indians is owned by the United States, or the United States are bound to the State within which it lies to extinguish the Indian claim thereto.

Src. 3. And be it further enacted, That in the making of any such exchange or exchanges it shall and may be lawful for the President solennly to assure the tribe or nation with which the exchange is made that the United States will forever secure and guaranty to them and their heirs or successors the country so exchunged with them, and, if they prefer it, that the United states will canse a patent or grant to be made and executed to them for the same: Provided always, That such lands shall revert to the United States, if the Indians become extinct or abandon the same

SEc. 8. And be it further enacted, That for the purpose of giving effect to the pres visions of this act the sum of five hundred thousand dollars is hereby appropriated, to be paid out of any money in the Treasury not otherwise appropriated.

[Treaty of Fort Gibson, February 14, 1833. (7 Stat., 414.) See Senate Ex. Doc. 78, Fifty-firat Con. gress, first session, pp. 3, 4, for explanation of this treaty.]

* * And whereas it appears from the Creek treaty made with the United States by the Creek Nation, dated twenty-fourth day of January, eighteen hundred and twenty-six, at the city of Washington, that they had the right to select, and did. select, a part of the country described within the boundaries mentioned above in said Cherokee articles of agreement; and

Whereas both the Cherokee and Creek Nations of Indians west of the Mississippi, anxious to have their bonndaries settled in an amicable manner, have met each other in council and, after full deliberation, mutually agreed upon the boundary lines between them: Now, therefore, the United States on one part, and the chiefs and head meu of the Cherokee nation of Indians west of the Mississippi on the other part, agree as follows:

ARTICLE 1. The United States agree to possess the Cherokees and to guarantee it to them forever, and that guarantee is luereby pledged, of seven millions of acres of land, to be bounded as follows, viz: Beginning at a point on the old western Territorial line of Arkansas Territory, being twenty-five ailes north from the point where the Territorial line crosses Arkansas River; thence running from said north point south, on the said Territorial line, to the place where said Territorial line crosses the Verdigris River; thence down said Verdigris River to the Arkansas River; thence down said Arkansas to a point where a stone is placed opposite to the east or lower bank of Grand River at its junction with the Arkansas; thence running south forty-fonr degrees west one mile; thence in a straight line to a point four miles northerly from the mouth of the North Fork of the Canadian; thence along the said four-mile line to the Canadian; thence down the Canadian to the Arkansas; thence down the Arkansas to that point on the Arkansas where the eastern Choctaw boundary strikes said river, and running thence with the western line of Arkansas Territory as now defined to the southwest corner of Missouri; thence along the western Missouri line 
to the land assigned the Senecas; thence on the south line of the Senecas to Grand River; thence up said Grand River as far as the south line of the Osage Reservation, extended, if necessary; thence up and between said south Osage line, extended west, if necessary, and a line drawn drawn due west from the point of beginning to a certain distance west, at which a line running north and south from said Osage line to said due west line will make seven millions of acres within the whole described boundaries. In addition to the seven millions of acres of land thus provided. for and bounded, the United States further guarantee to the Cherokee Nation a perpetual outlet west and a free and unmolested use of all the country lying west of the western boundary of said seven millions of acres as far west as the sovereignty of the United States and their right to soil extend: Provided, however, That if the saline, or salt plain on the great western prairie shall fall within said limits prescribed for said outlet the right is reserved to the United States to permit other tribes of red men to get salt on said plain in common with the Cherokees, and letters patent shall be issued by the United States as soon as practicable for the land hereloy guaranteed.

ART. 2. The Cherokee Nation hereby relinquish and quitclaim to the United States all the right, interest, and title which the Cherokees have or claim to have in and to all the land ceded, or claimed to have been ceded to said Cherokee Nation by said treaty of sixth May, one thousand eight hundred and twenty-eight, and not embraced within the limits or boundaries fixed in this present supplementary treaty or articles of conventiou and agreement.

ART. 5. These articles of agreement and convention are to be considered supplementary to the treaty before mentioned between the United States and the Cherokee Nation west of the Mississippi, dated sixth of May, one thousand eight hundred and twenty-eight, and not to vary the rights of the parties to said treaty any further than said treaty is incousistent with the provisions of this treaty, now concluded, or these articles of convention and agreement.

[Treaty of New Echota, December 29, 1835. 7 Stat, 478.]

Whereas the Cherokees are anxious to make some arrangements with the Government of the United States whereby the difficulties they have experienced by a residence within the settled parts of the United States under the jurisdiction and laws of the State governments may be terminated and adjusted; and with a view to reuniting their people in one body and securing a permanent home for themselves and their posterity in the country selected by their forefuthers without the territorial limits of the State sovereignties, and where they can establish and enjoy a government of tbeir oholce, and perpetuate such a state of society as may be most consonant with their views, habits, and condition, and as may tend to their individual comfort and their advaucement in civilization.

ARTICLE 1. The Cherokee Nation hereby cede, relinquish, and convey to the United States all the lauds owned, claimed, or possessed by them east of the Mississippi River, and hereby release all their claims upon the United States for spoliations of every kind, for and in consideration of the sum of five millions of dollars, to be expended, paid, and invested in the mauner stipulated and agreed upon in the following articles. * * *

ART. 2. (After reciting the boundaries of the lands that the United States had by the treaty of May 6, 1828, and the supplementary treaty of February 14, 1833 (supra), guaranteed and secured to be conveyed by patent to the Cherokee Nation), "and whereas it is apprehended by the Cherokees that in the above cession there is not contained a sufficient quantity of land for the accolumodation of the whole nation on their removal west of the Mississippi, the United States, in consideration of the sum of five hundred thousand dollars therefor, herelyy covenant and agree to convey to the said Indians an i their descendants, by patent in fee simple, the following additional tract of land, situatied between the west line of the State of Missouri and the Osage Reservation, beginning at the southeast corner of the same, and runs north along the east line of the Osage lauds, fifty miles to the northeast corner thereof, and thence east to the west line of the State of Missouri ; thence with said line south fifty miles; thence west to the place of beginning, estimated to contain eight hundred thousand acres of land; but it is expressly understood that if any of the lands assigned the Quapaws shall fall within the aforesaid bounds the same shall be reserved and excepted out of the lands above grauted, and a pro rata reduction shall be made in the price to be allowed to the United States for the same by the Cherokees.

ART. 3. The United States also agres that the lands above ceded by the treaty of Feb. 14, 1833, including the outlet, and those ceded by this treaty, shall all be included in one patent executed to the Cheroke Nation of Indians by the President of the United States according to the provisions of the act of May 28, 1830. 
ART. 5. The United States hereby covenant and agree that the lands ceded to the Cheroke Nation in the foregoing article shall, in no future time, without their consent, be included within the territorial limits or jurisdiction of any State or Territory. But they shall secure to the Cherokee Nation the right, by their national conntils, to make and carry into effect all such laws as they may deem necessary for the gov. ernment and protection of the persons and property within their own country belonging to their people or such persons as bave connected themselves with them; provided always, that they shall not be inconsistent with the Constitution of the United States and such acts of Congress as have been or may be passed regulating trade and iutercourse with the Indians; and also, that they shall not be considered as extending to such oitizens and Army of the United States as may travelor reside in. the Indian country by permission, according to the laws and regulationsestablish: by the Government of the same.

[Treaty of Wrohington, Aug. 6, 1846. (9 Stat., 871.) See Senate Ex. Doc. 78, Fifty-first Congress, first session, pp. 4 and 5 , for explanation of this treaty.]

Whoreas serious difficulties have for a considerable time past axisted between the different portions of the people constituting and recognized as the Cherokeee Nation of Indians, which it is desirable should be speedily settled, so that peace and harmony may be restored among them; aud whereas certain clains exist on the part of the Cherokee Nation, and portions of the Cherokee people, against the United States: Therefore, with a view to a final and amicable settlement of the difficulties and claims before meutioned, it is mutually agreed by the several parties to this convention, as follows, viz:

ARTICLE 1. That the lands now ocoupied by the Cherokee Nation shall be secured to the whole Cherokee people for their common use and benefit; and a patent shall be issued for the same, including the eight hundred thousand acres purchased, together with the outlet west, promised by the Utited States, in conformity with the provisions relatjng thereto, contained in the third article of the treaty of 1835 , and in the third section of the act of Congress approved May twenty-eighth, 1830, which anthorizes the President of the United States, in making exchanges of lauds with the Indian tribes, "to assure the tribe or nation with which the exchange is made that the Uuited States will forever secure and guarantee to them and their heirs or suecessors, the country su exchanged wilh thein; and if they prefer it that the United States will cause a patent or graut to be made and executed to them for the same: Provided, always, That such lands shall revert to the United States if the Indians becomes extinct or abandon the same." * * *

ART. 4. * * In cousideration of the foregoing stipulation on the part of the United States, the "Western Cherokees," or "Old Settlers," hereby release and quitclain to the United States all right, title, interest, or claim they may have to a common property in the Cherokee lands east of the Mississippi River, and to exclusive ownership to the lands ceded to them by the treats of 1833 west of the Mississippi, including the outlet west, consenting and agreeing that the said lands, together with eight huudred thousand acres ceded to the Cherokees by the treaty of 1835, shall be and remain the common property of the whole Cherokee people, themselves included. * * *

Nork.-(a) In the meantime, viz, on December $3 \mathrm{~L}, 1838$, a patent had issued to the Cberokee Nation fur all the lands stipulated anil agreed to be conveped to it by the secoud and third articles of the treaty of December 29, 1835, viz, tho 7,000,000 acres, the outlet lands, and the 800,000 acres, naking in all 14,374, 135.14 acres, according to the provisions of the act of $M$ ay 28,1830 .

(b) The treaty of 1828 between the United States of America and the United Mexican states ( 8 stat. 374 ) contirus the validity of the limits described in the treaty with Spain of 1819, and in the second article the boundary line between the two countries is described and bounded as follows:

6.* * * Then, tollowing the course of the Rio Roxo (or Red River) westward to the degiee of longitude 100 west from London and 23 from Washington, thence crossing the said Red River anoi running thence by a line due north to the river Arkansas. * * " "Therefore at the date of the treaty of 1835 with the Cherokeos, the sovereignty of the Uniter States exteuded to the 100th meridian, and heuce the perpetual outlet guaranteed the Cherokees extends only that far. This outlet is what is known as the Cherokee lands west of the Arkansas River, or rather west of the 7,000,000 acres mentioned in the treaty. (Seo letier of Commissioner of Indian Affairs to the Secretary of the Interior, Feliruary 17, 1882, pp. 35, etc., House Ex. DGc. 54, Forty-seventh Congress, second session.

[Treaty. Washington, July 19,1866. 14 Stat., 799.]

ART. 13. The Cherokees also agree that a conrt or courts may be eatablished by the United States in said Territory with such jurisdiction and organized in such manner 
as may be prescribed by law: Provided, That the judicial tribunals of the nation shall be allowed to retain exclusive jurisdiction in all civil and criminal cases arising within their country in which mombers of the nation, by nativity or adoption, shall be the only parties, or where the cause of action shall arise in the Cheroliee Nation, except as otherwise provided in this treaty.

ART. 16. The Unitad States may settle friendly Indians in any part of the Cherokee country west of $96^{\circ}$, to be taken in a compact form in quautity not exceerling one hundred and sixty acres for each member of oach of said tribes thus to be settled; the boundaries of each of said districts to be distinctly marked, and the land conveyed in fee simple to each of said tribes, to be held in cominon or by their members in soveralty as the United States may decide.

Said lands thus disposed of to be paid for to the Cherokes $\mathrm{Nation}$ at such price as may be agreed on between the said parties in interest, subject to the approval of the President; and if they shonld not agree, then the price to be fixed by the President.

The Cheroke Nation to retain the right of possession of and jurisdiction over all of said country west of $96^{\circ}$ of longitude until thus sold anỏ occupied, after which their jurisdiction and right of possession to terminate forever as to each of said distriets thus sold and occupied.

ART. 17. The Cherokee Nation hereby cedes in trust to the United States the tract of land in the State of Kansas which was sold to the Cherokees by the United States undrr the provisions of the second article of the treaty of 1825 ; and also that strip of the land ceded to the nation by the fourth article of said treaty which is included in the State of Kanses, and the Cherokees consent that said lands may be included in the limits and jurisdiction of the said State.

AR'T. 26. The United States guarantee to the people of the Cherokee Nation the quiet and peaceable possession of their country and protection against domestic feuds aud insurrections and against hostilities of other tribes. They shall also be protected against interruptions or intrusion from all unauthorized eitizens of the United States who may attempt to settle on their lands or reside in their Territory. In case of hostilities among the Indian tribes, the United States agree that the party or parties commencing the same shall, so far as practicable, make reparation for the damage done.

ART, 31. All provisions of treaties, heretofore ratified and in force, and not inconsistent $w$ ith the provisions of this treaty, are hereby reaffirmed and declared to be in full force; and notbing herein shall be construed as an acknowledgment by the United States, or as a relinquishment by the Cherokee Nation of any claims or demands under the guaranties of former treaties, except as herein expressly provided.

\section{DISPOSITION OF LANDS WEST OF $96^{\circ}$ UNDER ARTICLE 16 OF THE TREATY} OF 1866.

\section{COMANCHES AND KIOWAB.}

[See Senate Ex. Doc. No. 78, Fifty-first Congress, first session, p. 7.]

Prior to the date of the treaty with the Cherokees of Jaly 19, 1866, by the sixteenth article of which the United States $w$ as authorized to settle friendly Indians on the lands west of ninety-sixth degree, the United States had by treaty of October 18, 1865 (14 Stát., 717), set apart a large tract of country, embracing some 2,279,84 acres of the lands of the Cherokee Nation, being that part of the Outlet lands that lies west of the Cimarron River, for the use and occupation of the Kiowa and Comanche Indians. This treaty, however, did not divest the Cherokeo Nation of its title to said lands, nor vest any title thereto in the Comanches and Kiowas, the United States having at the date of said treaty no right to interfere with the title of the Cherokee Nation to its lands, except in cases purely political. (See United States $v$. Ben Reese, post, p. 47, and cases cited.)

By the treaty of October 21, 1867 (15 Stat., 581), the Kiowas and Comanches relinquished all right to permanently occupy territory outside a reservation created by that treaty, and which embraced no part of the Cherokee country. In this way they relinquished all claim to that part of the Cherokee Outlet lands, which had been illegally set apart to them by the treaty of 1665. By the treaty of 1867 they were indeed given the right to hant on lands north of their present reservation and south of the Arkansas River, so long as the buffialo might range therein in such numbers as to justify the chase, but this right to hunt was not such an appropriation of the lands 
as was contemplated by the sixteenth article of the treaty of 1866 with the Cherokee Nation.

\section{CHEYENNES AND ARAPAHOES.}

[Idem, pp. 7-11.]

By the treaty of October 21, 1867 (15Stat., 593), a traet of conntry west of ninety-sixth degree, bounded by the Arkansas River on the east, the thirty-aeventh parallel of north latitude being the southern boundary line of the State of Kansas on the north, and the Cimarron or Red Fork of the Arkansas River on the west and south, within which boundaries are included 4,294,739 acres of the Cherokee lands west of the 960, all lying west of the Arkansas River, was set apart for the nndisturbed use and occupation of the Cheyenne and Arapuho Indians, as from time to time they might be willjng, with the consent of the United States, to admit among them.

The Cheyennes and Arapahoes having represented that they did not understand the location of their reservation, as defiued by the treaty of 1867 , and that they had never been upon said reservation, and did not desire to go there, but desired to locrtiv on the north fork of the Canadian River, some 60 miles below Camp Supply, the reservation upon which they are now located lying entirely south of the Cherokes country, was set aside for them by Executive order dated Augnst 10, 1869. (For bistory of subsequent negotiations had with the Cheyennes and Arapahoes in regard to these lands, and status of the grant of 1867, as viewed by the Interior Department, see House Ex. Doc. No. 54, Forty-seventh Congress, second session; Senate Ex. Doc. No. 13,.Forty-eighth Congress, first session.)

Title of the Osage and Kansas, Pawnees, Otoe and Mrssouria, Ponca, and Nez Phree and Tonkawa Tribes of Indians to Portions of the OUThe LANDS.

\section{OSAGE AND KANSAS INDIANS.}

\section{[Act June 5, 1872, 17 Stat., 228.]}

\section{AN ACT to confirm to the Great and Little Osage Indians a reservation in the Indian Territory.}

Whereas by the treaty of eighteen hundred and sixty-six between the United States and the Cherokee Nation of Indians, said nation ceded to the United States all its lands west of the ninety-sixth meridian west longitude, for the settlement of friendly Indians thereon; and whereas by act of Congress approved July fifteenth, eighteen hundred and seventy (16 Stat., 362), the President was authorized and directed to remove the Great and Little Osage Indians to a lonation in the Cherokee country west of the uinety-sixth meridian, to be designated for them by the United States authorities; and whereas it was provided by the same act of Congress that the lauls of the Osages in Kansas should be sold by the United States, and so much of the proceeds thereof as were necessary should be appropriated for the payment to the Cherokees for the lánds set apart for the said Osages west of the ninety-sixth meridian; and whereas under the provisions of the above-mentioned treaty and act of Congress, aud concurrent action of the authorities of the United States and the Cherokee Nation,"the said Osages were removed from their former homes in the State of Kansas to a reservation set apart for them in the Indian Territory, at the time of the removal supposed to be west of the said ninety-sixth meridian, and bounded on the east thereby, aud upou which said Osages bave made snbstantial and valuable improvements; and whereas by a recent survey and establishment of the ninety-sixth meridian it appears that the most valuable portion of said Osage reservaticn, and upon which all their improvenents are situated, lies east of the said meridian; and whereas it therefore becane necessary to select other lands in lien of those found to be east of the estallished ninety-sixth meridian for said Osage. Indians; and wheress a traot has accordıngl been selected lying between the western boundary of the reservations heretofore set apart for said Indians and the main channel of the Arkansas River, with the south line of the State of Kansas for a northern boundary, and the north line of the Creek country and the main channel of the Arkansas River for a southern and western boundary; and whereas the act of Congress, approved July fifteenth, eighteen hundred aud seventy, restricts the said reservation for said Orage Indians to "a tract of laud in compact form equal in quantity to one hundred and sixty acres for each member of said tribe;" and whereas in a letter of the Cherokee delegation, addressed to the Secretary of the Interior on the eighth day of April, eighteen hundred and seventy-two, on behalf of the Cherokee Nation, containing their approval of and assent to the proposition to provide for the settlement of the Osage and $\mathrm{Kaw}$ Indians on that portion of the Cherokee country lying west of the ninety-sixth degree west longitude, south of Kansa, east and north of the Arkansas River. Therefore, 
Be it enacted by the Senate and House of Representatives of the United States of America n Congress assembled, That in order to provide said Osage tribe of Indians with a resirvation, and secure to them a sufficient quantity of land suitable for cultivation, ehe following -described tract of country west of the established ninety-sixth meridian, tn the Indian Territory, be, and the same is hereby set apart for and confirmed as their ireservation, namely : Bounded on the east by the vinety-sixth meridian, on the south and west by the north line of the Creek country and the main channel of the Arkansas River, and on the north by the south line of the State of Kansas: Provided, That the location as aforesaid shall be made under the provisions of article sixteen of the treaty of eighteen hundred and sixty-six, so far as the same may be applicable thereto: And provided further, That said Great and Little Osage tribe of Indians shall permit the settlement within the limits of said tract of land (of) the Kansas tribe of fndians, the land so settled and occupied by said Kansas Indiaus, not exceeding one hundred and sixty acres for each member of said tribe, to be paid for by said Kansas tribe of Indians out of the proceeds of the sales of their lands in Kansas, at a price not exceeding that paid by the Great and Little Osage Indians to the Cherokee Nation of Indjans.

[Act March 8, 1873; 17 Stat., 538.]

- * Indian Bureau.-That the Secretary of the Treasury is hereby authorized and directed to transfer from the proceeds of eale of the Osage Indian lands in Kansas, made in accordance with the twelfth section of the act of Congress approved July fifteenth, eighteen hundred and seventy, the sum of one million six hundred and fifty thousand six hundred dollars, or so much thereof as may be necessary, to pay for lands purchased by the Osages from the Cherokess, and to place the same on the books of his Department to the credit of the Cherokee Indians. The same shall bear interest at the rate of five per cent, in accordance with the act of Congress approved June fifth, eighteen hundred and seventy-two, entitled "An act to confirm to the Great and Little Osage Iudians a reservation in the Indian Territory," and the acts of Congress and treaties therein mentioned and referred to, whenever the amount to be so transferred shall be certified to the said Secretary of the Treasury by the Secretary of the Interior.

[Aot March 3, 1883; 22 Stat., 624.]

* * That the sum of three hundred thousand dollars is hereby appropriated to be paid into the treasury of the Cherokee Nation out of the funds due under appraisenent for Cherokee lands west of the Arkansas River, which sum shall be expended as the acts of the Cherokee legislature direct, this amonnt to be immediately available: Provided, That the Cherokee Nation, through its proper authorities, shall execute conveyances, natisfactory to the Secretary of the Interior, to the United States in trust only for the benefit of the Pawnees, Poncas, Nez Percés, Otoes, and Missourias, and Osages now occupyiug said tract, as they respectively occupy the same before the payment of said sum of money.

[Deed June 14, 1883.]

Deed of conveyance of this date made by the Cherokee Nation to the United States in trust for the use and benefit of the Osage and Kunsas Indians, agreeably to the foregoing item.

[Act May 29, 1872; 17 Stat., 190.]

APPRAISEMENT OF LANDS WEST OF THE ARKANSAS RIVER.

SzC. 5. That the President of the United States and the Secretary of the Interior are bereby authorized to make an sppraisement of the Cherokee lands lying west of the nipety-sixth meridian of west longitude, and west of the land of the Osage Indians, in the Indian Territory, and south of the southern line of the State of Kansas, ceded to the United States by the Yhorokee Indians under their trebty of July nineteenth, eighteen hundred and sixty-six, for the settlement of friendly Indians, and report the saue to Congress: Provided, That the Secretary of the Interior be, and he hereby is, authorized to negotiate with the Southeru Chejennes aud Arapahoes for the relinquishment of their claim to the land ceded to them by the second article of the treaty of (Notuber twe.ty-eighth, eighteen linndred and sixty-seven, out of the cessiop nade by tha Cherokees iu the treaty of July vineteentb, eighteen hundred and dixty-six; such relinquishmeut, if obtained, to be in consideration of a snfficient 
and permanent location for the said Cheyennes and Arapahoes upon the Iands ceded to the United States by the Creeks and Seminoles in the treaties of March twenty. first and June fourteenth, eighteen hundred and sixty-six ; and that the Secretary report the action taken by him under this provision to Cougress at its next session.

[Aot Jaly 31, 1876 ; 19 Stat., 120.]

* * For this amount, or so much thereof as may be required to pay the expenses of a commission to be appointed by the Secretary of the Interior, to appraise oertain Cherokee lands in the Indian Territory, in aecordance with the fifth section of the act making appropriations for the expenses of the Indian Department, approved May twenty-ninth, eighteen hundred and seventy-two, five thousand dollars. * * *

[Senate Ex. Doo. No. 78, Fifty-frat Congress, first session, page 12.]

NoTE. -The total area of Cherokee lands lying west of the Arkansas River amounts to $6,574,486.55$ acres, which on June 23,1879 , in pursuance of the au thority vested in him by the act of May 29, 1872 (17 Stat., 190), and the act of July 31, $1876^{\circ}$ (19 Stat., 120), supra, were appraised by the President as follows, viz:

\section{Pawnees.}

$6,344,572.51$ acres, at 47.49 cents per acre .................... \$3,013,037.48,50 $230,014.04$ acres, at 70 cents per acre.........................

$6,574,486.55$ $161,009.82 \frac{80}{100}$

3174.047 .31 , 30

This apprajement was objected to by the Cherokees as illegal and in violation of the sixteentb article of the treaty of 1866. (For history and details of appraisement, correspondence, etc., see House Ex. Doc. No. 54, Forty-seventh Congress, second session.)

[Aot April 10, 1876; 19 Stat., 28.]

\section{PAWNEES.}

Sec. 4. That the following-described reservation in Indian Territory be, and the same is hereby, set apart for"the use and occupation of the Paw nee tribe of Indiaus, namely, all that tract of country between the Cimarron and Arkansas rivers em. braced within the limits of townships tweuty-one, twenty-two, twenty-three, and twenty-four north, of range four east, townships eighteen, nineteen, twenty, twentyone, twenty-two, twenty-three, and twenty-four north, of range five east, townshipe eighteen, nineteen, twenty, twenty-one, twenty-two, and twenty-three north, of range six east of the Indian meridian: Provided, That the terms of the sixteenth article of the Cherokee treaty of July nineteenth, eighteen hundred and sixty-six, shsll be complied with so far as the same may be applicable thereto: And provided furthor, That the sum to be paid to the Cherokees by the Pawnees for such quantity of the land herein described as may be within the limits of the Cherokee conntry, west of the ninety-sixth meridian of west longitude, shall not exceed seventy cents per acre : And provided also, That the portion of the reservation herein described lying within the territory ceded to the United States by the third article of the Creek treaty of June fourteenth, eighteen hundred and sixty-six, shall be paid for by said Pawnees at the rate of thirty cents per acre.

[Act March 3, 1883, 22 Stat., 624.]

* * That the sum of three hundred thousand dollars is hereby appropriated to be paid into the treasury of the Cherokee Nation, out of the funds due under appraisement for Cherokee lands west of the Arkansas River, which sum shall be expended as the acts of the Cherokee legislature direct, this amount to be immediately available: Provided, That the Cherokee Nation, through its proper authorities, shail execute conveyances, satisfactory to the Secretary of the Interior, to the United States in trust only for the benefit of the Pavnees, Poncas, Nez Perces, Otoes and Missourias, and Osages, now occupying said tract, as they respectively occupy the same before the payment of said sum of money.

[Deed June 14, 1885.1

Deed of conveyance of this date from the Cherokee Nation to the United States in trust for the pse and benefit of the Pawnee Indians agreeably to the foregoing item. 
OTOES AND MISSOURIAS.

[Act March 3, 1881, 21 Stat.; 380.]

AN ACT to provide for the sale of the remainder of the reservation of the Confederated Otoe and Missouria Tribes of Indians in the State of Nebraska and Kanas, and for other purposes.

SEC. 5. That the Secretary of the Interior may, with the consent of the Indians, expresser in open council, secure other reservation lands upon which to locate said Indians, cause their removal thereto, and expend such sum as may be necessary for their comfort and advancement in civilization, not exceoding one hundred thousand collars, including costs of surveysavd expense of removal, the same to be drawn from the fund arising from the sale of their reservation lands under the act approved August tifteenth, eighteen hundred and seventy-six.

[Executive order, Jane 25, 1881.]

\section{DEPARTMENT OF THE INTERIOR,}

Washington, June 25, 1881.

SIR: Agreeably to your recommendation of the 13th instant, the following described lands in the Indian Territory, west of the ninety-six th degree, west longitude, in the tract ceded to the United Strtes by the Cherokees for the settlement of friendly Indians, by the sixteenth article of their treaty of .July 19,1866, are hereby designated and assigned for the use and occupation of the Confederated Otoe and Missonria tribes of Indians, under the provisions of the act of Congress approved March 3, 1881 (21 Stats., p. 381), namely :

Acres.

Township 22 north, range 1 east, contsining ..................... 23,013, 70

Township 23 north, range 1 east, containing ..........................

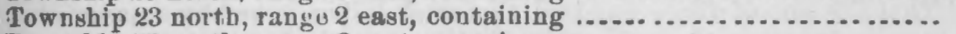

Township 23 north, range 2 east, containıng .........................

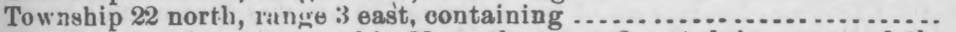
Also that portion of towuship 23 north, range 3 east, ljing west of the

Arkansas Kiver, containing .................................... 14,098.84

Total aereage .............................................. 129, 113.20

The papers which accompanied your letter before noted are herewith returned.

S. J. KIRKWOOD,

Secretary.

The Commissioner of Indian Afrairs.

[Act March 3, 1883, 22 Stat., 624.]

* * That the sum of three huudred thousand dollars is hereby appropriated to be paid into the treasury of the Cherokee Nation out of the funds due under appraisement for Cherokee lands west of the Arkansas River, which sum shall be expended as the acts of the Cherokee legislature direct, this amount to be immediately available: Provided, That the Cherokee Nation, through its proper authorities, shall execute conveyances, satisfactory to the Secretary of the Interior, to the United States in trust only for the benefit of the Pawnees, Poncas, Nez Perces; Otoes, and Missourias, and Osages, now occupying said tract, as they respectively occupy the same before payment of said sum of money.

[Deed June 14, 1883.]

Deed of conveyance of this date from the Cherokee Nation to the United States in trust for the use and benefit of the Otoe and Missouria tribe of Indians agreeably to the foregoing item.

\section{PONCAS.}

[Act August 15, 1876, 19 Stat., 192.]

* * For this amount for subsistence, including the Yankton, Sioux, and Poncas, and for purposes of their civilization one million dollars: * * * Providedfurther, That the Secretary of the Interior may use $n$ the foregoing amounts the sum of twenty-five thousaud dollars for the removal of the Poncas to the Indian Territory, and providing them a home therein, with the consent of said band. 
[Act Maroh 3, 1877; 19 Stat., 287.]

* * For this amount, for sulusistence, including the Yankton, Sioux, and Poncas, and for other purposes of their civilization, one million one hundred and twentyfive thousand dollars. * * And provided further, That the sum of fifteen thousand dollars of this upprepriation, in addition to that heretofore appropriater, may be used for the removal and permanent location of the Poncas in the Indian Territory.

\section{[Act May 27, 1878; 20 Stat.,76.]}

For this amount, or so much thereof as may be necessary, to be expended under the direction of the Secretary of the Interior, to be immediately available in the removal of the Ponea Indians from their present location on the Quapaw Reservation, Indian Territory, to a new one west of the Kaw or Kansas and between the Arkansas and Shakaskia rivers, aud for their settlement thereon, preparation of land for cnltivation, purchase of agricultural implements, wagons, stock cattle, and such other articles as nıy be required for their advancement in civilization, including the empluyment of such skilled labor as may be necessary to aid and teach them civilized pursuits with a view to their future self-support, thirty thousand dollars, and which amount may be immediately available; in all, forty-five thousand five hundred dollars.

\section{[Act March 3, 1881 ; 21Stat., 422. .]}

* * For the purchase of one hundred and one thouaand eight hundred and ninety-four acres of land in the Indian Territory, where most of these Indians (Poncas) are now located, fifty thousand dollars.

\section{[Act March 3, 1883 ; 22 Stat., 624.]}

* * That the sum of three hundred thousand dollars is hereby appropriated, to be paid into the treasury of the Cherokee Nation, out of the funds due under appraisement for Cherokee lands west of the Arkansas River, which sum shall be expended as the acts of the Cherokee legislature direct, this anount to be immediately available: Rrovided, That the Cherokee Nation, through its proper anthorities, shall execute convey ances, satisfactory to the Secretary of the Interior, to the United States in trust only for the benefit of the Pawnees, Poncas, Nez Percés, Otoes and Missourias, and Osages now occupying said tract, as they respectively occupy the same before payment of said sum of money.

[Deed June 4, 1883.]

Deed of conveyance of this date from the Cherokee Nation to the United States in trust for the use and benefit of the Ponca tribe of Indians, agreeably to the foregoing item.

\section{NEZ PERCÉS AND TONKAWAS.}

[A ot May 27, 1878; 20 Stat., 74.]

* * * Nez Percés of Joseph's Band.-For this amount, or so much thereof as may be necessary, to be expended under the direction of the Secretary of the Interior in the removal of the Nez Percés Indians of Joseph's band, now held as prisoners of war at Fort Leavenworth, Kausas, to such suitable location in the Indian Territory as the United States has a right to use for such purpose, consistent with existing treaties or arrangements with tribes occupying Indian Territory, and for their settlement thereon, and for clothing, subsistence, and such other articles as may be required for their advancement in civilization, including. the employment of such skilled labor as may be necessary to aid in teaching them civilized pursuits with a view to their future self support, the sum of twenty thousand dollars: Provided, That such amout of the above sum as may be necessary for said removal and for subsistence for remainder of the fiscal year ending June thirtieth, eighteen hundred and seventyeight, may be imuediately available.

[Act March 3, $1883 ; 22$ Stat., 624.

* * That the sum of three huvdred thousand dollars is hereby appropriated, to be paid into the treasury of the Cheroke Nation out of the funds due ander appraisement for Cherokee lands west of the Arkansas River, which sum shall be 
expended as the acts of the Cherokee lerrislature direct, this amount to be immedidiately available: Provided, That the Cherokee Nation, through its proper authorities, shall execute conveyances, satisfactory to the Secretary of the Interior, to the United States in trust only for the benetit of the Pawnees, Poncas, Nez Percés, Otoes and Missourias, and Osages now occupying said tract, as they respectively occupy the same before the payment of said sum of money.

[Deed June 14, 1883.]

Deed of conveyance of this date from the Cherokee Nation to the United States in trust for the use and benefit of the Nez Percés tribe of Indians, agreeably to the foregoing item.

[Act Jaly 4, 1884; 23 Stat., 90. ]

* * In support and civilization of Joseph's band of Nez Perce Indians in the Indian Territory, twenty thousand dollars; and of this amount a sum not $\theta x c e e d i n g$ one thousand six hundred and tweuty-five dollars may be paid, under the direction of the Secretary of the Interior, to James Rulben, for expenses incurred by him in taking thirty-three Nez Percé Indians from the Indian Territory to Irlaho; and the Secretary of the Interior is authorized to expend the balance of this appropriation for the removal of the Nez Perce Indians now in the Indian Territory to some other location, and if he deem it proper so to do, and for their support at such new location.

[Act March 8, 1885; 23 Stat., 378.]

* * For support and civilization of Joseph's band of Nez Perc6 Indians, eighteen thousand dollars; and the Secretary of the Interior is anthorized to expend. of this amount a sufficient sum, which is hereby mude immediately available for the purpose, for the removal of the Nez Perce Indians now in the Indian Territory to some other location, if he deem it proper so to do.'

\section{[Deed May 22, 1885.]}

Deed of relinquishment and quitclaim from Nez Perce Indians to the United States in trust for the use and benefit of such Indians as the United States might see fit to locate thereon, of all their right, title, and interest in and to said lands.

\section{[Aet August 7, 1882 ; 22 Stat., 349.$]$}

Be it enacted by the Senate and House of Representatives of the United States of America in Congress assembled, That the legislative council of the Cherokee Nation may execute alease of the salines or salt cleposits on the plains, not to exceed three in number, located on the lands of the Clierokee Nation, lying west of the ninetv-sixth degree of longitude in the Indian Territory, and so much land connected therewith as may be necessary for the working of the same for a period of not exceeding twenty years, with right of a highway for ingress and egress to be reservel for such purpose and to facilitate the manufacture of salt, and the conditions of which lease shall insure the payment to the Cherokee national anthorities of a royalty of not less than one dollar per ton, said lease beiug subject to such conditions and to the proper jurisdiction of the Cherokee national legislatare, and said lease and conditions subject to the approval of the Secretary of the Interior: Provided, That the proceeds of such royalty from the manufacture of salt shall be in arldition to the educational fund of said nation: And provided fusther, That said salines shall continue snbject to any rights of the Uniter States under sections fifteen and sixteen of the treaty of July nineteenth, eighteen hundred aud sixty-six, with the Cherokee Indians; and said lease or leases shall be liable to revocation by the legislative council of the Cherokee $\mathrm{Na}$ tion and the Secrotary of the Interior for the non-performance of any such conditions.

[Senate Ex. Doc. No. 78, Fifty-first Congress, first session, pp. 14, 15.]

\section{Payments to the Cherokee Nation on account of lands west of $96^{\circ}$, exclusive of amount paid by Osages (\$1,099,137.41).}

Amount appropriated by an item contained in the act of Cougress ap. proved June 16,1880 (21 Stat. 48), to be paid into the treasury of the Cherokee Nation out of the funds due said nation for its lands in the Indian Territory west of the Arkansas River ..................... $\$ 300,000.00$ 
Amount paid for the lands assigned to the Ponea Indians ont of the appropriation made by an item contaiued in the act of Congress approved

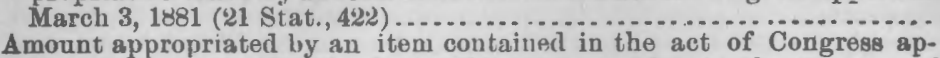
proved March 3, 188:3 (22 Stat., 624), to be paid into the treasury of the Cherokee Nation out of the funds due under appraisement for Cherokee lands west of the Arkansas River . . . . . . . . . . . . . . . . . . .

Amount appropriated by the act of Congress approved October 19,1888 (25 Stat.,609), to pay certain freedmon and Delaware and Shawnee Indians their proportion of the amonnt appropriated by the act of Congress approved March 3, 1883 (24 Stat., 624) ........................

Amount appropriated by an item contained in the act approved March 2,1889 (25 Stat., 994), to enable the Secretary of the Interior to ascertain who are entitled to share in the distribution of the $\$ 75,000$ appropriated Octolver 19, 1888 (25 Stat., 609) ..........................

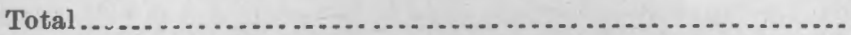

$\$ 48,389.46$

$300,000.00$

$75,000.00$

$5,000.00$

728, 389.46

(NoTE.-It may not require the whole of the $\$ 75,000$ appropriation to pay the freedmen and Delaware and Shawnee Indians, and the appropriation, $\$ 5,000$, may not be exhansted in detérmining who are entitled to share in the distribution of the appropriation of $\$ 75,000$.

APPROPRIATION ITEMS RECOGNIZING THE LEGISLATURE OF THE CHEROKEES AS A LAW-MAKING BODY.

[Aot June 16, 1880; 21 Stat., 248.]

That the sum of three hundred thousand dollars is hereby appropriated, to be paid into the treasury of the Chorokee Nation, out of the fund due said nation for its lands in the Indian Territory west of the Arkansas River, as per estimate of the Secretary of the Interior, and which sum shall be expended, as the acts of the Cherokee legislature direct, to relieve the destitution of the Cheroke people caused by the failure of the crops during the past season by reason of the drought; this amount to be immediately available.

[Act March 3, 1881; 21 Stat., 428.]

For the pnrchase of one hundred and one thousand eight hundred and ninety-foul acres of land in the Indian Territory, where most of these [Ponca] Indians are now located, fifty thousand dollars.

\section{[A.t Maroh 3, 1883; 22 Stat., 624.]}

That the sum of three hundred thousand dollars is hereby appropriated, to be paid into the treasury of the Cheroke Nation, out of the fund due under appraisement for Cherokee lands west of the Arkausas River, which sum shall be expended as the acts of the Cherokee legislature direct; this amount to be immediately available: Prnvided, That the Cherokes Nation, through its proper authorities, shall execute conveyances, satisfactory to the Secretary of the Interior, to the United States in trust only for the benefit of the Pawnees, Poncas. Nez Perces, Otoes and Missourias, and Osages now occupying said tract, as they respectively occupy the same, before the payment of said sum of money.

[Act October 19, 1888; 25 Stat., 608.]

Whereas by an item in the act making appropriations for snndry civil expenses of the Government for the fiscal year ending June thirtieth, eighteen handred and eighty-four, and for other purposes, approved March third, eighteen hundred and eighty-three, the sum of three hundred thonsand dollars was appropriated, to be paid into the treasury of the Cheroke Nation, out of the fund due uuder appraisement for Cherokee lands west of the Arkansas River, which sum shall be expended as the acts of the Cherokee legislature direct; and

Whereas by an act of the Cherokee legislature, which was passed over the veto of the principal chief and became a law on the nineteenth day of May, eighteen hundred and eighty-three, the principal chief was clirected to cause the said sum of three hundred thousand dollars to be paid out per capita to the citizens of the Cherokee Nation by blood, and which sum has been paid out only to Cherokee citizens by blood, as directed by said act; and 
Whereas by the said act of the Cherokee legislature, the aforesaid freedmen. Delaware and Shawnee Indians have been deprived of their legal and just dues guaranteed them by treaty stipulations: Therefore,

Be it onaoted by the Senate and House of Representatives of the United States of America in Congress assembled, That there be, and hereby is, appropriated, out of any money in the Treasury not otherwise appropriated, the sum of seventy-five thousand dollars, or so much thereof as may be necessary, to carry out the provisions of this act; and the amount actually expended shall be charged against the Cherokee Nation, on account of its lands west of the Arkansas River, aud shall be a lien on said lands, and which shall be deducted from auy payment hereafter made on account of said lands. The said sum, or so much thereof as may be necessary, shall be by the Secretary of the Interior distributed per capita, first, among such freedmen and their descendants as are mentioned in the ninth article of the treaty of July nineteenth, eighteen hundred and sixty-six, between the United States and the Cherokee Nation of Indians; second, among the Delaware tribe of Indians incorporated in to the Cherukee Nation by the terms of a certain agreement entered into between the said Cherokee Nation and Delaware Indians, under the provisions of the fifteenth article of the aforesaid treaty, on the eighth day of April, eighteen hundred and sixty-seven; and, third, among the Shawnee tribe of Indians incorporated into the.Cherokee Nation by the terms of a certain agreement entered into between the saill Cherokee Nation and Shawnee Indians, under the provisions of the aforesaid article and treaty, on the seventh day of June, eighteen hundred and sixty-nine, and approved, respectively, by the President of the United States and the Secretary of the Interior on the ninth day of June, eighteen hundred and sixty-nine, in such manner and in such amount or anıounts as will equalize the per capila payment made to Cherokees by blood, in accordance with the act of the Cherokee legislature aforesaid, out of the sum of three hundred thousand dollars appropriated by the act of March third, eighteen hundred and eighty-three, aforesaid.

[Act March 2, 1889, 25 Stat., 994.]

To enable the Secretary of the Interior to ascertain who are entitled to share in the per capita distribution of the sum of seventy-five thousand dollars appropriated by the act approved.October nineteenth, eighteen hundred and eighty-eight, entitled "An act to secure to the Cherokee freedmen and others their proportion of certain proceeds of land under the act of March third, eighteen huudred and eighty-three, and to make payment thereof," the sum of five thousand dollars, or so much thereof as may be necessary, and to compensate in such sum as he may deem reasonable any duly anthorized agent or agents aeting for said freedmen and rendering them aid in obtaining the allowance of said seventy-five thousand dollars, the sum of fifteen thousand dollars, or so much thereof as may be necessary; and the amount so expended in ascertaining to whorn said money shall be paid shall be charged against the Cherokee Nation on account of its lands, and shall be deducted from any payment hereafter made on account of said lands. And said Secretary is hereby authorized and directed to make inquiry and report to the vext seseion of Congress what other sums of money, if auy, have been appropriated by the Cherokee Nation in violation of their treaty obligations in reference to freedmen in said nation, and what sum would be required to secure to said freedmen those treaty rights in respect to the same.

-

$\$$

*

*

\section{JUDICIAL OPINIONS ON TITLE.}

[Holden v. Joy, 17 Wall., 211. U. S. S. C., Dec. T., 1871.]

STATEMENT OF THE CASE.

1. The treaty of the $29 \mathrm{th}$ December, 1835 , between the United States and the Cheroke $\Theta$ Indians, was not made in virtue of the act of May, 1830, authorizing an "exchange" of lands west of the Mississippi for the territory claimed or occupied by any tribe of Indians within the limits of any State or Territory, but was made under the treaty-making power vested by the Constitution in the President and Senate.

2. The Indian tribes are capable of taking as owners in fee simple lands by purchase where the United States in form, and for a valuable and adequate considera. tion, to sell them to them.

3. Such sale is properly made by a treaty. 
4. The above-mentioned treaty of 29 th December, 1835 , made such a sale to the Cherokee Indians of the lands west of the Mississippi, known as the "Cherokee neutral lands," and the fact and validity of the sale have been recognized by Congress through appropriations made in execution of the treaty making it.

Referring to the clause in the patent to the Cherokees, which provides that the lands embraced therein shall revert to the United States if the Indians become extinct or abandon the same, the United States Supreme Court said:

6** * * Possessed as the United States were of the fee-simple title to the neutral lands discharged of the right of occupancy by the Osage Indians, it was clearly competent for the proper authorities of the Uniter. States to convey the same to the Cherokee Nation. Subsequent acts of the United States show that the stipulations, covenants, and agreements of the treaty in question were regarded by all the Departments of the Government as creating binding obligations, as fully appoars from the fact they all concurred in carrying the provisions into full effect. (Minis $v$. United. States, 15 Pet., 448; Porterfield v. Clark, 2 How., 76.) Appropriations were made for surveys, and surveys were ordered, and plats were made, and on the 1st December, 1838 , a patent for the land promised was issued by the President in full execution of the second and third articles of the treaty.

"Among other things, it is recited in the patent that it is issued in execution of the agreements and stipulations contained in the said several treaties, and that the Unitod States do give and grant unto the Cherokes Nition the two described tracts of land as surveyed, containing the whole quantity therein mentioned, to have and to hold the same, tógether. with all the rights, privileges, and appurtenances thereto belong. ing to the said Cherokee Nation forever, subject to certain couditions therein specified, of which the last one is thit the lands hereby granted shall revert to the United States if the said Cherokee Nation becomes extinct or abandons the premises. * * *

"Objection is made by the appellant that the treaty. Was inoperative to convey neutral lands to the Cherokee Nation, which may be well admitted, as none of its provisions purport proprio vigore to make any such conveyance. Nothing of the kind is pretended, but the stipulation of the second article of the treaty is that the United States covenant and agree to convey to the said Indians and their descendunts, by patent in fee simple, the described additional tract, meaning the tract known as the neutral lauds; and the third article of the treaty stipulates that the lands ceded by the treaty, as well as those ceded by a prior treaty, shall all be included in one patent, to be executed te the Cherokee Nation of Indians by the President accordiug to the provisions of the before-mentioned act of Congress.

"Suppose that is so, still it is insisted that the President and Senate in concluding such a treaty could not lawfully covenant that a patent should issue to convey lands which belonged to the United States without the consent of Congress, which can not be admitted. On the contrary, there are many authorities where it is held that a treaty may convey to a grantee a good title to such lands without an act of Cougress conferring it, and that Congress has no constitutional power to settle or interfere with rights under treaties, except in cases purely political. Much reason exists, in view of those anthorities and others which might be referred to, for holding that the objection of the appeliaut is not well fonnded, but it is not necessary to decide the question in this case, as the treaty in question has been fully carried into effect, and its provisions have been repeatedly recognized by Congress as valid. Congress, on the 2 nd July, 1836, appropriated $\$ 4,500,000$ for the amount stipulated to be paid for the lands coded by the Cherokees in the first article of the treaty, deducting the cost of the land to be conveyed to them west of the Mississippi under the second article of the same treaty, which is the precise amount stipulated to be paid for the concession, deducting the consideration which the Indians agreed to allow for the neutral lands. Appropriations were also made by that act to fulfil and execute the stipulations, convenants, and agreements contained in the fourth, eleventh, seventeenth, and eighteenth articles of the treaty, and for the removal of the Cherokees, and for surveying the lands set apart by treaty stipulations for the Cherokee Indians west of the Mississippi River. Commissioners were appointed to adjudicate the claims of individual Cherokees, as provided in the thirteenth article of the treaty, and their compensation was fixed by Congress, and appropriations were made by Congress for that purpose. Such a board was duly constituted, consisting of two commissioners, and it was made the duty of the Attorney-General, in case of their disagreement, to decide the point in difference.

"Prior treaties between the United States and the Cherokee Nation proving to be insufficient to protect and promote their respective interests, the contracting parties on the 15th of July, 1866, made a new treaty of that date by the first article of which they declare that the pretended treaty made with the so-called Confederate States by the Cherokee Nation on the 7th of October, 1861, is void, which is all that need be said upon the subject, as both parties repudiate the instrument and concur that it is of no effect. 
"Two objections are made to the title of the appellee as affected by that treaty, in addition to those urged to show that the prior treaty between the same parties was inoperative and invalid. It is contended by tine appellant that the Cherokee possessory right to the neutral lands was extinguished by the seventeenth article of the treaty, which undoubtelly is correct, but the conclusion which he attempts to deduce from that fact can not be sustained, that the Cherokee Nation abandoned the lands within the meaning of the last condition inserted in the patent by which they acquired the same from the United States.

'Strong doubts are entertained whether that condition in the patent is valid, as it was not anthorized by the treaty under which it was issued. By the treaty the United States covenanted and agreed to convey the lands in fee-simple title, and it may be well held that if that condition reduced the estate couveyed to less than a fee, it is void, but it is not necessary to decide that point, as it is clear that if it is valid it is a condition subsequent, whick no one but the grantor in this case can set up under any circumstances.

"Even if the rule was otherwise, still the point could not avail the appellant, as the parties manifestly waived it in this case, nor is it true that the sale in trust by the Cherokee Nation to their former grautor constitutes such an abancloument of the premises as that contemplated by the condition inserted in the patent."

[United States v. Ben Reese, 5 Dill., 405. United States district court, western district of Arkansas, May term, 1879.]

In the case of the United Sates $v$. Ben Reese, which came up on demurrer to information filed by the United States district attorney charging defendant with a violation of section 5388 United States Revised Statutes, "Lv unlawfully cutting timber on lands situated and lying in the Cherokee Nation in the Indian country in the western district of Arkansas, which said lands in pursuance of law may be reserved and purchased by the United States for military or other purposes," the United States court for the western district of Arkansas after reviewing the various treaties and acts of Congress under which the Cherokee Nation derives title to its lands, held that the title of the United States passed to the Cherokee Nation under the treaty of 1833 .

"**** Now, the question arises, what kind of a title do these several treaties and this law of 1830 give the Cherokees to their lands? If it were not for the treaty of 1835 , the treaty of 1833 is broad enough in its terms to convey a fee-simple title. This treaty is subsequent in date to the act of 1830 , which contained the clause that the lands should revert to the United States if the Indians 'become extinct or abandon the same.' 'There is no limitation to the title conveyed by the Uniteci States of 1833 . If such treaty is inconsistent with the law of 1830 , it repealed so much of it as was inconsistent. Besides the act did not make any grant, it only provided that it might be done.

"The treaty-making power was notlimited by its terms, as the authority to make a treaty with the Indian tribes was one which the treaty-making power derived from a source higher than an act of Congress, to wit, the Constitution. And by this power the President and the Senate of the United States could make a treaty with any Indian tribe, extending to all objects, which, in the intercourse of uations, had usually been regarded as the proper subject of negotiation and treaty, if not inconsistent with the nature of our Government and the relation between the States and United States. This treaty-making power conld make a sale or grantiof land without an act of Congress. It could lawfully provide that a patent should issue to convey lands which belong to the United States without the consent of Congress, and in such case the grantee would have a good title. (Holden vs. Joy, 17 Wallace, 247; United States v8. Brooks, 10 lioward, 442; Meigs v8. McClurg, 9 Cranch, 11.)

"Congress has no constitutional right to interfere with rights under treaties, ex-

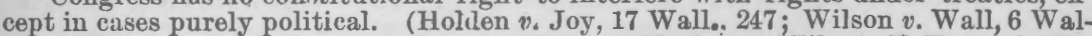
lace, 89; Insurance Company v. Carter, 1 Peters, 542; Doe $v$. Wilson, 23 Howurd, 461; Mitchell $v$. United States, 9 Peters, 749; The Kansas Indians, 5 Wallace, 737; 2 Story on Constitution, sec. 1508; Foster $v$. Neilson, 2 Peters, 254; Crews v. Bnrcham, 1 Black, 356; Worcester $v$. Georgia, 6 Peters, 562; Blair v. Pathkiller, 2 Yerger, 407; Harris $v$. Burnett, 4 Blackford, 369.) If title passed by the treaty of 1833 there were no restrictions upon it.

"But it may be asked, how could this title be held to be a title in fee when the word heir's was not used in the grant? At the common law, by a rule which in this country is purely teclinical, the word heirs is necessary. But this rule did not apply to grants to a corporation aggregate. The fee passed without the gords heirs or successors, because in judgment of law a corporatiou never dies and is immortal by means of perpetual succession. (4 Kent Com. 7.) 'This tribe of Indians may be regarded under the law as a corporation, aggregate. It has been claimed by some

$$
\text { S. Rep. } 281 \longrightarrow 3
$$


that t. sis title obtained under the treaty of 1833 could not be a fee simple title be, cause it was taken under the general law prohibiting the alienation of Indian lands and that this was such a restriction upon the title as to take away its foe simple character. But this act was not in existenee until the 30th of June, 1834. But it is said the treaty of 1833 did not operate to convey the lands described therein. 'This point is not entirely free from doubt. But it does seem to me that the words used in the first section of the treaty are sufficient to operate as a cession of the land mentioned in the treaty. The United States agrees to possess the Cherokees and to guarantee to them forever, and that guarantee is hereby pledged of seven millions of acres of land. The United States agrees to possess what Why, the land doscribed. And to guarantee what, and for how long? Why, not the possession, but the land, and forever. It does seem to me that this was a cession of the land described. This opinion is confirmed by the language of the second article of the treaty of 1835. (Rev. I. T., 68.) It is: "The United States also agrees that the lands above, ceded by the treaty of February 14, 1833." This language is a recognttion of the cession of the lands. If they had already been ceded to the Cherokees forever by the treaty of 1833, then the agreement by the United States, by the third article of the treaty of 1835, to give them a patent for these lands according to the provisions of the act of Congress of May 28, 1830, was a mere mudum pactum. It was an attempt to place a restriction upon a title which had already passed, and which, according to the 1st section of the treaty of 1833 was to be evidenced by patent.

"I am unable to see what consideration passed to the Indians to induce them to take a title of less grade, under the $3 r d$ article of the treaty of 1835 , when they, by the terms of the 1st article of the treaty of 1833, had one of a higher grade. Now, unless the treaty was afterwards modified by some other treaty or law, and my construction of it is the correct one, it can not be held that these lands of the Cherokees are 'lands of the United States,' in the sense of the language of section 5388 of the general statutes. Although the construction may be at fault, still it throws some light on what must have been intended by the treaty of 1835.

"But suppose the condition contained in the patent is valid, let us see what effect that has upon the title. The condition is that the lands revert to the United States if the said Cherokees become extinct or abandon the same. Now, the first of these conditions is one which would be silently engrafted on the grant, independent of any express words. When there is a grant, and the grantee and his heirs become extinct, the land escheats to the State, whether the grantes be an individual or a body of individuals. In an ordinary patent, absolute from the government, the implied right of escheat to the sovereign lies behind the patent. In this case it is expressed.

"Therefore, that expressed condition does not take away the character of a fee simple title. But the other one, against abandonment, does. This leaves the title less than a fee. But what character does it have 8 Mr. Blackstone, (book 2d, chap. 7, p. 109,) says: 'A base or qualified fee, is such a owe as hath a qualification subjoined thereto, and which must be determined whenever the qualitication annexed to it is at an end. As in case of a grant to $A$ and his heirs, tenants of the manor of Dale. In this instance, whenever the heirs of A cease to be teuants of the manor the grant is entirely defeated. * * * This estate is a fee, because by possibility it may endure forever in a man and his heirs. Yet, as that duration depends apon the concurrence of collateral circumstances which qualify and debase the purity of the donation, it is, therefore, a qualitied or base fee.' Chancellor Kent (vol. 4, p. 10 of his Commentaries) says: "A qualified, base, or determinable fee, is an interest which may contiuue forever, but the estate is liable to be determined withont the aid of a conveyance, by some act or event, circumscribing its continuance or exteut. It is the uncertainty of the event, and the possibility that the fee may last forever, that renders the estate a fee and not merely a freehold.' If the condition attached to the fee is one which is certain to happen, then there is a reversion. If such condition is one which may never happen, there is not a reversion, but only a possibility of a reversion. (4th Kent's Com. 9; 1 Washburm on Real Property, p. 90, pl. 86, 87, and 88.) Mr. Washburn (in pl. 88 , vol. 1, p. 90) says: 'If the estate be to A and his heirs till $\mathrm{B}$ comes back from Rome, the right to have it when he comes back is not a revercion, but a mere possibility. He may not come back, and if he were to die before he same back, the estate would become absolute in the grantee.'

"Here is a grant made to the Cherokees, having conditions which may never happen, and in view of the facts that the Cherokee Indians are not likely to become extinct. and that they are now occupying the lands with no intention of abandowing the same, there is only a remote possibility of either event happening. In such case there is not an absolute right of reversion in the United States, but only a possibility of reversion. There is a broad distinction between the rights of the grantee in case of a reversion, and a mere possibility of reversion, when there is only a possibility of reversion, all the estate is in the feoffee, notwithstanding the 
qualification." (4 Kent's Com. 11; 2 Bouvier's Inst., sec. 1699, p. 220; 1 Washburn on Real Property, pl. 89 , p. 90.)

"This Indian title being a base, qualified, or determinable fee, with only the possibility of a reversion, and not the right of reversion in the United States, all the estate is in the Cherokee Nation of Indians. I cannot, therefore, see how these lands which have been depredated upon, can be held to be 'lands of the United States' in the sense of the language used in sec. 5388. * * * The demurrer is therefore sustained."

\section{[U. S. v. Payne, 2 MoCrary 289, -U. S. Dist. Ct. W. D. Ark., May T., 1881.]}

* * * The lands upon which the defendant elaims to have settled were originally a part of the Louisiana purchase. By such purchase the title thereto was vested in the United States. By the act of Congress May 28, 1830, the President was anthorized to set apart the country now known as the Indian country, or Indian Territory, into certain districts for the use and occupancy of Indians, to be removed there from east of the Mississippi River.

The provisions of the act of 1830 were supplemented by treaties bargaining and conveying certain tracts to certain triles, by far the greater part of it having been conreyed to five nations, to wit, the Cherokees, Choctaws, Chickasaws, Creeks, and seminoles. These assignments were made to these tribes by the several treaties made with them, and the President, under the act of 1830 , put them in possession thereof.

Did the power which made this treaty have a right to reserve this land Most certainly. The treaty making power has a right to convey title to the lands of the United States without an act of Congress, and if a treaty acts directly on the subject of the grant, it is equivalent to an act of Congress, and the grantee has a good title. Holden $v$. Joy, 17 Wallace 247; United States $v$. Brooks, 10 Howard 442; Meigs $v$. MeClung, 9 Cranch 11; as long ago as the Cherokee Nation $v$. Georgia, 5 Pet. 1 ; and Worcester $v$. the State of Georgia, 6 Pet. 515. The Supreme Conrt of the United thates, speaking through that most eminent of all American judges, Chief Justice John Marshall, held that a treaty with an Indian tribe was like a treaty with a foreign nation as far as the powers of the contracting parties were concerned; that it, like a treaty with in foreign power, was a law equally as sacred and equally as binding as a law of Congress.

Now we must look to the acts of the Government since the adoption of this treaty in order to understand its purpose. We find that in the year 1866 it entered upon the policy of settling tribes of Indians other than the five eivilized tribes in the Indian country. Since that time by treaties, laws, and Executive orders of the President, it has settled upon reservations in the Indian country the Cheyennes, Arapahoes, the Kiowas, the Comanches, the Wichitas, the Pawnees, the Sae and Fox, the Nez Perces, the Poncas, the Modocs, the Kansas, the Osages, the Pottawatomies, the Absentee Shawnees, as well as some other small tribes. This explains why the treaty making power thought on March 21, 1866, that there was an urgent necessity of the Government for more lands in the Indian Territory. This shows that the Government has not only desired to locate other Indians in the Indian Territory, but to a great extent it has consummated that desire. It is a matter of public history that a number of these tribes which have been removed to the Indian conntry, taking advantage of the embarrassment of the Government, growing out of the war of the rebellion, bad gone on the war path. The Government was desirous of securing peace with them and of settling them upon reservations where they could be civilized. It entered into treaties by which they were to be and were removed to Indian country. Then again white people in other Jocalities were pressing on other tribes and demanding of the Government their removal. To get them out of the way of the white settlements and to locate them where they could be free from intrusion by the whites, they were removed to the Indian country. "Tis trne but few of these tribes were sottled on the lands in controversy; but I cite the conduct of the Goverament in order to arrive at its policy in regard to the Indian country, and from that policy to receive aid in the construction of the 3 rd article of the Seminole treaty. The Government wanted to locate other Indians and freedmen thereon. The mesunirg of the United States in regard to locating other Indiaus thereiu is plain when we consider what action it has taken since that time in regard thereto. True, Congress has recently prohibited the location of certain other tribes of Indians in that country, but it has not by any law changed the general policy.

A treaty like a statute, must be construed to give it effect, if possible, and courts always adhere to this rule. In construing this treaty we have a right to take into consideration the situation of the parties in making the treaty. To get at this intention we have a right to consider the construction the parties to the treaty, and who were to be affected by it, have given it, and what has been their action under it. 'The action of the United States which I have cited is sufficient to show its con- 
struction of the treaty. It is a matter of public notoriety that the other party to the treaty has agreed with the United States in its construction. Then we have both parties to it agreeing upon the same construction. That is the construction to be taken as the true one unless the parties to it were mutually led into this construction by fraud, accident, or mistake. In a case where the mutual construction was in the face of the language used and the rights of third persons intervened, the language would be taken as governing

\section{[U. S. v. Rogers, 23 Fed. Rep., 658. U. \$. D. C. W. D. Ark., Dec. T, 1884.]}

In the case of the United States $v 8$. Rogers, which came up before the same court upon a question of jurisdiction between the district of Kansas and the western district of Arkansas under the act of January 6, 1883 (22 Stat., 400), the court again reviews the character of the title of the Cherokee Nation, as previously discussed in United States v8. Reese (supra) and says in regard to the outletilands:

$6 * * *$ By looking at the title of the Cherokees to their lands, we find that they hold them all by substantially the saine kind of titile, the only difference being that the outlet is incumbered with the stipulation that the United States is to permit other tribes to get salt on the salt plains. With this exception, the title of the Cherokee Nation to the outlet is just as fixed, certain, extensive, and perpetual as the title to any of their lands. This court held in the case of U. S. v. Reese, 5 Dill., 405 , that ' the Cherokees hold their land by title different from the Indian titie, by occupation; they derived it by grant from the United States. It is a base, qualified or determinable fee without the right of reversion, but only a possibility of reversion, in the United States. This in effect puts all the estate in the Cherokee Nation.'

"Prior to the act of Congress of January 6, 1883, all of the country lying west of Missouri and Arkansas, known as the 'Indian Territory', was attached by a law of the United States to the judicial district of Arkansas. And the district court of such district had jurisdiction over all the country described above as Indian country for the trial of offenses when committed by a certain class of persons, or upon a certain class of persons. Up to the time of the act above referred to there was no question as to the Cherokee outlet being in the jurisdiction of the district court for the western district of Arkansas. It was Indian country and Indian country, lying west of Missouri and Arkansas, and a part of what was known as the Indian country. On the date above named, Congress passed an act entitled 'An act to provide for holding a term of the district court of the United States, at Wichita, Kansas, and for other purposes,' which provides, by section 2, that all that part of the Indian Territory Iying north of the Canadian River and east of Texas and the 100th meridian not set apart and occupied by the Cherokee, Creek, and Seminole Indian tribes, shall, from and after the passage of this act, be annexed to and constitute a part of the United States judicial district of Kansas, and the United States courts at Wichita and Fort Scott, in the district of Kansas, shall have exclusive original jurisdiction of all offenses committed within the limits of the territory hereby annexed to said district of Kansas against any of the laws of the United now or that may hereafter be operative therein, (22 Stat., 400.)

"By the treaties and patent above referred to the Cherokee outlet, was beyond question, set apart to the Cherokees and to that extent was in a condition the converse of that which is necessary to attach it to the district of Kansas. It matters not what may have been the extent of their title. If they had a title of any degree whatever, it was set apart to them. Now, at the time of the commission of this alleged offense, was it occupied by the Cherokee tribe of Indians I If it was set apart and occupied by this tribe, it is not in the jurisdiction of the district court of Kansas.

"The evidence in this case shows that the Cherokee Nation has constantly, and all the time since it obtained the outlet, claimed it, and exercised acts of ownership and control over it. The Nation has collected at different times a irazier's tax from white men who were grazing their stock on it. Individual Indians have gone on it and fenced up large tracts of land on the outlet. Different individual Indians have gone out and lived on it, and now live on it. That since the passage of this law of January 6,1883 , the Cherokee Nation has leased to citizens of the United States for grazing purposes $6,000,000$ acres of this outlet. That under the provisions of the sixteen tharticle of the treaty of 1866 with the United States, it has soid tracts of land on this outlet for reservations to the Pawnees, Poncas, Nez Perces, Otoes and Missourias. The very country where this alleged offonse was committed, was, at the time of its commission, leased to the cattlemen as a part of the 6,000,000-acre lease. That the Cherokee Nation never has abandoned any part of the outlet except what it has sold. It claims the title and possession of the outlet and of that part of it where this alleged offense is shown to have been committed. The United States, the grantor, has admitted its title to it. Then, does the Cherokee Nation occupy the country where the offense was committed It Ibecomes necessary in this connection to ascertain what is meant by the 
word 'occupy.' It is well to remember that the country was set apart to the Cherokee Nation-not to individual Cherokees, but to the Cherokee Nation as such. When Congress used the phrase 'not set apart and occupied,' did it mean to imply that to constitute an occupation the Cherokee Nation must acturlly reside on the land, as a tenant resides in the house of his landlord? How could the nation do that This would be impossible. Did it mean to say that all the country upon which individual Indians, members of the tribe, did not actually reside, was after the passage of the act to be in the jurisdiction of the district court of Kansas? If so, the jurisdiction of that court would be of the most rambling, meandering, and uncertain character; as it is a notorious fact that there are millions of acres scattered all over the Cherokee Nation which are not occupied either by the nation or its citizeus in the sense of actual residence upon the land. We find that the word 'occupied' or 'occupation,' may be so used in law, in convection with other expressions, or under the peculiar facts of the case, as to signify actual residence. Under the peculiar facts here, actual residence of the Cherokee Nation wonld be an impossibility and an absurdity. When Congress used the word 'occnpied,' it could have meant no more than possession of the country. To have possession does not require actual residence. Words are to be taken according to their customary legal meaning. We find that, ordinarily, in the law, the words 'occupation,' or 'occupy,' or 'occupied,' mean, as used, subject to the will and control possessio pedis; that the words 'occupation,' or 'occupy,' or occupied,' are synonymous with subjection to the will and control. Wherever there is a subjection of land to the will and control of another with title in him, it is occupied by that other. It is in the actual legal possession of that other. (Lawrence $v$. Fulton, 19 Cal., 690 ; Plume $v$. Seward, 4 Cal., 94; Bailey v. Irby, 2 Nott \& McC. (S. C.), 343; Jackson $v$. Woodruff, 1 Cow., 285; Jackson $v$. Halstead, 5 Cal., 219.) Messrs. Rapalje \& Lawrence, in their Law Dict., Vol. 2, p. 893 , in defining the word 'occupation' say, 'In its usual sense, it is where a person exercises physical control over land.' Hence, when a nation or body of people have the title to land, and the same is subject to their will and control, it is occupied by them-legally, it is in their possession.

"The Goverwment of the United States occupies all of its public lands. The Cherokee Nation occupies and is in the actual legal possession of all its lands to which it has title, and to which it has not relinquishegd such title. This, in my judgment, is the only reasonable interpretation which can be give to this word ' ocoupied,' as used in the act of Congress of January 6,1883 . If this be so, there is left no room for any other coustruction of this act of Congress than that it does not put in the jurisdiction of the district court of Kansas any of the Cherokee country to which the nation has title, and which is subject to its will and control. But it is claimed in this case that the Cherokees no longer have any title to the country where the alleged offense is said to have occurred, as they sold it to the Cheyennes and Araphoes in 1866.

"We find by the treaty of May 22, 1866, between the United States and the Cheyennes and Arapahoes, a reservation was set apart for them which included as a part thereof the very country where this alleged crime was committed. By the terms of the second article of the treaty they were not required to settle on said reservation until such time as the United States shall have extinguished all claims of title thereto on the part of other Indians to said reservation. They did not settle on this reservation and claimed that they did not understand the location of it as defined by the treaty with them of August 16, 1868, and therefore refused to go upon it. The President of the United States, by Executive order of August 10, 1869, located them on their present reservation on the North Fork of the Canadian River. By the sixteenth article of the treaty of July 27, 1866, between the United States and the Cherokees, it was agreed 'that the United States may settle friendly Indians in any part of the Cherokee country west of 96 degrees, to be taken in compact form, in quantity not exceeding 160 acres for each member of each of said tribes thus to be settled; the boundaries of each of said districts to be distinctly marked, and the land conveyed in fee simple to each of said tribes, to be held in common or by their members in severalty as the Untted States may decide; said lands thus disposed of to be paid for to the Cherokee Nation at such price as may be agreed on between the said parties in interest, subject to the approval of the President, and if they should not agree, then the price to be fixed by the President; the Cherokee Nation to retain the right of possession of and jurisdiction over all of said country west of 96 degrees of longitude, until thus sold and occupied, after which their jurisdiction and right of possession to terminate forever as to each of said districts thus sold and occupied.' The plain meaning of this provision of the treaty is that when the United States should desire any of the outlet for the settlement of friendly Indians on the same, that the Cherokees wonld sell the same to such Indians and make title in fee simple to them for the same, the purchase price to be paid by them, or the Goverument of the United States for them, to the Cherokees. But until the country, or any part of it, is so sold and occupied, the right of possession and jurisdiction over all of said 
country west of 96 degrees of longitude to be retained by the Cherokees. Hers is a plain recognition of the title of the Cherokees by the Government of the United States, with their right of possession and jurisdiction. Inasmuch as therenever was any sale by the Cherokees to the Chejennes and Arapahoes of the country where this offense was committed, that the same was never sold by them and occupied by the Cheyennes and Arapahoes, the country is still in the condition of being set apart and occupied by the.Cherokees, and does not come under the designation of Indian country not set apart and occupied by the Cherokees. Therefore, it is not in the jurisdiction of the United States district court for the district of Kansas, and that court is not one in which a trial of the case of Rogers can be had, and the petitioner can not be removed to said district, and the 'warrant of removal' will be refused and the petitioner in the proceedings by habeas corpus will bo discharged."

[U. S. v. Soule et al., 30 Fed. Rop., 918. J. S. C. C. D. of Kansas, June T., 1887.]

In the case of the United States $v$. Soule et al., in the United States circuit court for the district of Kansas, which came up on plea to the jurisdiction, under the act of January 6, 1883 (supra), the conrt held-in contradistinction to the ruling of the United States court for the western district of Arkansas in the case of United States v8. Rogere, previously cited-that the district court for Kansas had jurisdiction over the Cherokee Outlet lands, and in regard to the title of the Cherokee title thus expressed itself:

6** * We go back to the treaty of 1828 (7 Stat. at Large, 311). The preamble of that treaty recites: 'Whereas, it being the anxious desire of the Government of the United States to secure to the Cherokee Nation of Indians a permanent home, etc. Article two then reads: "The United States agree to possess the Cherokee Nation, and to guaranty it to them forever, and that guaranty is hereby solemnly pledged of seven millions of acres of land to be bounded as follows.' Then follows a description by metes and bounds of the tract above indicated, of 7,000,000 of acres. Then, in the same article, are these words: 'In addition to the seven millions of acres thus provided for and bounded, the United States further guaranty to the Cherokee Nation a perpetual outlet west, and a free and unmolested use of all the country lying west of the western poundary of the above described limit and as far west as the sovereignty of the United States and their right of soil extends.' 'The treaty of February 14th, 1833 (7 U. S. Stat. at Large, 414), reiterates the same grants, attaches to the provision quoted for outlet, etc., a proviso: "If the saline or salt plain on the great western pruirie shall fall within said limits, the right is reserved to the United States to permit other tribes of red men to get salt on said plain in common with the Cherokees,' and also that letters patent shall be issued as soon as practicable for the land so guaranteed.

"Subsequent treaties have reduced the boundaries of this 7,000,000 tract and also provided for cessions of some portions of the territory west to other tribes. In pursuance of this treaty, patent was issued for all the lands including the outlet west. No distinction was made in the granting clause between the 7,000,000 tract and the outlet west. Now, is this sutlet within the meaning of the act of 1883 'set apart and oceupied' by the Cherokee Nation? 'That it was set apart to thatnation is evident, but wasit occupied \& Doubtless, in a certain sense it was occupied, because the Cherokee Nation had a title and right to possess it; but if Congress had meant by this act to include all land owned by the Cherokees, the words 'set apart' would have been ample, and the word 'occupied' was superfluous. Obviously some distinctive matter was intended. to be expressed by the use of that word. The significance of it is evident, from the langnage of the proviso in article 2 heretofore quoted. Manifestly Congress set apart that 7,000,000 acres as a home, and that was thereafter to be regarded set apart and occupied 'because,' as expressed in the preamble of the treaty, 'Congress was intent upon securing a permanent home.' Beyond that, the guaranty was of an outlet, not territory for residence, but for passage ground over which the Cherokees miglrt pass to all the unoccupied domains west. But while the exclusive right to this outlet was guaranteed, while patent was issued conveying this outlet, it was described and in tended obviously as an ontlet, and not as a home. So, whatever righto of property the Cherokees may have in this outlet, it was not terxitory set apart for a home, and is not territory within the language of the act of 1883, 'set apart and occupied' by the Cherokee tribe. I think therefore that the district court of Kansas had jurisdiction over the territory in which this offense is charged to have been committed.

" I am aware that in the case of U. S. v8. Rogers (23 Fed. Rep., 658), Judge Parker, of the western district of Arkansas, has expressed a different conclusion, and has held that the jurisdiction over this outlet still remains in the district court for the western district of Arkansas. I have given his careful and elaborate opinion thorough study; and while, according to that opinion, the consideration which its careful preparation and which the distinguished ability of that learned judge com- 
pels, I am unable to yield to the force of his reasoning. Both the geographical argument and the double description in the act of 1883 lead me to a different conclusion, and to hold that the jurisdiction over the outlet is vested in the district court of Kansas. The plea to the jurisdiction of the district court will therefore be overruled, and the case certified back to that court for trial."

[Fastern Band of Cherokee Indians v. United States and Cherokee Nation. 20 C. C., 449. June, 1885.]

The status of the Cherokee Nation, one of the defendants, is entirely different. Il has its territorial possessions and boundaries, its constitution (very much like tht Constitution of the United States), its laws, its executive, legislative, and judiciae departments, with none of which can any State or the United States interfere.

Its relation to the United States are fixed by contracts set out in treaties and laws, to which as a nation, it has given its assent. The United States, by the terms of those contracts, has become trustee of its funds, which it has agreed to administer wocording to the provisions of those contracts. " * * The Clierokee Nation "has a right to stand upon the contracts of its treaties, ${ }^{*} *^{*}{ }^{*}$ and no act of Congress und no proceedings of the political departments of the Government in connection therewith can take away its vested rights thereto guaranteed by such treaties."

[Same v. Same, 117 U. S., 288.]

Nort.-On appeal to the Supreme Court of United States the decision of the Court of Claims was affirmed.

[Cherokee Nation v. Southern Kansas Rallway Company, 135 U. S. 656; Oct. T, 1889].

The fact that the Cherokee Nation holds these lands in fee simple under patents from the United States is of no consequence in the present discussion; for the United States may exercise the right of eminent domain, even within the limits of the several States, for the purposes necessary to the execution of the powers granted to the General Government by the Constıtution.

\section{OPINIONS OF ATTORNEYS-GENERAL.}

[Cherokee Lands. Removal of intruders. 16 Opinions, 470.]

Communications from your predecessor, dated July 11 and 18, 1879, request my opinion in relation to the then recent removal by the military of one J. W. Bell and others, attempting to settle upon the Cherokee lands west of $96^{\circ}$.

Part of these persons so attempting settlement, it appears, were white persons, and others half-breed Cherokees. It appears also that Bell claimed to have authority from the Department of the Interior for such settlement. But no such authority was produced.

So far as concerns persons who belong to the white race, and make no claim to Cherokee citizenship, there is, of course, no question. They must be considered as trespassers or intruders, and the Government is under treaty obligations to remove them. The question proposed by the War Department is whether, assurning Bell to be a citizen of the Cherokee nation, he was a trespasser upon the lands mentioned, and was rightfully expelled.

The question is to be answered hy reference to the provisions of the 16th article of the Cherokee treaty of 1866 , which are as follows:

The United States may settle friendly Indians in any part of the Cherokee country west of tie $96^{\circ}$, to be taken in a compact form in quantity not exceeding one hundred and sixty acres for each member of each of said tribes thus to be settled; the boundaries of each of said districts to be distinetly marked, and the land conveyed in fee simple to each of said tribes to be held in common or by their members in sereralty, as the United States may decide.

Said lands thus disposed of to be paid for to the Cherokee Nation at such price as may be agreed on between the said parties in interest, subject to the approval of the President; and if they should not agree, then the price to be fixel by the President.

The Cherokee Nation to retain the right of possession of and jurisdiction over all of said country west of $96^{\circ}$ of longitude until thus sold and occupied, after which their jurisdiction and right of possession to terminate forever as to each of said districts thus sold and occupied."

The fair interpretation of this article would seem to be that the lands to which it refers were absolutely reserved to the United States, upon the conditions therein named, for the settlement thereon of tribes of friendly Indians. "The jurisdiction and possession of the Cherokee Nation as to the lands from time to time remaining unsold and unoccupied would give no right to the nation to settle its citizens 
thereon until the privilege acquired by the United States to settle tribes of friendly Indians "in any part of the country west of $96^{\circ}$ " should be satisfied or in some authentic way be renounced; and this being so, no porson atternpting a settlement on these lands can justify under any authority given by the Cherokee Nation. On the contrary, it is the duty, as it is the interest of the Nation, to prevent its eitizens from making such settlement. It appears that Bell produced no evidence that such authority had been given him. But if he had, and the view above taken be correot, the United States, in the maintenance of their treaty privilege, would have been justified in ejecting him.

The parties to the treaty are jointly interested-the United States in using the lands for the purposes indicated, the Cherokees in obtaining payment for them. (Attorney-General Devens to Secretary of War, February 25, 1880.)

[Kansas School Isand Grant. Indemnity case, 16 Opinıons, 434.]

* * * The effect of the conveyance by the United States to the Cherokee Nation of this tract of land (Cherokee neutral lands) upon the purchase made by them under the treaty of 1835 was to vest in the tribe a fee simple to said tract (Holden $v$. Joy, 17 Wall., 211). This tribe did not hold this tract of land by the ordinary Indian title, which is one of occupancy only, which may be continued indefinitaly In such case the fee simple to the land is in the United States. The effect of this sale was to separate distinctly the tract from the public lands of the United States and vest it in private ownership. Nor is it perceived that any change in the rights thus aequired, or in the separation thus made, occurs by reason of the faet that afterwards the Cherokees conveyed the land to the United States upon certain defined trusts. It was no longer public land, and the only right which the United. States had in it after it had been reconveyed by the Cherokees was to hold it for the purpose of the trust upon which it had been received. * * * (Attorney-Gert) eral Devens to Secretary of Treasury, January 21, 1880.)

\section{CHEROKEE STRIP.}

[18 Opinions, 555.]

The lands lying in the "Cherokee Strip" which are leased to the whites are not lands of the United States within the meaning of section 5388, Revised Statutes.

\section{DEPaRTMENT OF JUSTICK,} February 24, $188 \%$.

SIR: By your letter of the 18th instant you request my opinion on three questions:

The first is, "Are the lands leased to the whites in Cherokee Strip lands of the United States, referred to in section 5388, Revised Statites, or otherwise 9"

The Cherokee Strip referred to in your inquiry, I assume, is the land described in the seventeenth article of the treaty of the 19th of June, 1866 (14 Stat., 804), by which the land therein described is ceded to the United States in trust, as set forth in the treaty. Section 5388 is almost a literal reënactment of the act of the $2 d$ of March, 1859, the title to which is "An act to protect the timber growing upon lands of the United States reserved for military and other purposes." The enactment in its terms limits its provisions to lands "which, in pursuance of law, may be reserved or purchased for military or other purposes." The section being highly penal, the eservation or purchase contemplated therein must be for some specific national purpose or use of the United States. The beneficiary of the proceeds of the land contained in the strip, by virtue of the provisions of the trust, is the Cherokee tribe of Indians. When the United States became the trustee the purpose of the trust was, and still is, the sale of the lands according to the terms of the treaty. This is not such a purpose or reservation for the United States as is contemplated by section 5388, referred to in your first inquiry. ***

I am, very respectfully,

The Secretary OF War.

A. H. Garland.

\section{EFFEC'T OF TREA'TIES.}

[Worcester v. Georgia, 6 Pet., 581.]

The language used in treaties shall never be construed to their prejudice. If words be made use of which are susceptible of a more extended meaning than their plain import as connected with the tenor of the treaty, they should be considered as ised only in the latter sense. *** How the words of the treaty were understood by this unlettered people, rather than their critical meaning, should form the rule of construction. (See also the Kansas Indians, 5 Wall., 760; Choctaw Nation v. United States, 119 U. S., 27, 28.) 
[Fellows v. Blacksmith, 19 How., 366.]

* * A treaty, after executed and ratified by the proper authorities of the Government, becomes the supreme law of the land, and the courts can no more go behind it for the purpose of annulling its effect and operation than they can behind. an act of Congress. (1 Cranch, 103; 6 Pet., 735; 10 Howard, 422; 2 Pet., 307, 309, 314; 3 Story Const. Law, p. 695.)

[Wilson $v$. Wall., 6 Wall., 89.]

* * * Congres has no constitutional power to settle the rights under treaties except in cases purely political. (Insurauce Co. v. Cantor, 1 Pet., 542; Doe v. Wilson, 23 Howard, 460; The Kansas Indians, 5 Wall., 737; Foster v. Neilson, 2 Pet.! 254; Crews v. Burnham, 1 Black, 356; Blair v. Pathkiller, 2 Yerger, 407; Harris $v$. Barnett, 4 Blackford, 369.)

[Roichart v. Felps, 6 Wall., 165.]

* * * Congress is bound to regard the public treaties, and it had no power to organize a board of revision to nullify titles confirmed many years before by the authorized agents of the Government.

[The Sinking Fund Cases, 99 U. S., 719.]

* * * The United States can not, any more than a State, interfere with private rights, except for legitimate governmental purposes. * * " They can not legislate back to themselves, without making compensation, the lands they have given this corporation to aid in the construction of its railroad; neither can they by legislation compel the corporation to discharge its obligations in respect to the subsidy bonds otherwise than according to the terms of the contract already made in that sonnection. The United States are as much bound by their contracts as individuals. If they repudiate their obligations, it is as much repudiation, with all the wrong ind reproach that term implies, as would be if the repudiator had been a State, wunicipality, or a citizen. No change can be made in the title created by the grant of the lands, or in the contract for the sudsidy bonds, without the consent of the corporation. All this is indisputable.

And in the same case, in the dissenting opinion of Justice Strong, on page 736, this doctrine, which was the unanimous opinion of the court, is stated thus:

Now, where is the power of Congress to add new terms to any contract made with the United States, or made between any two private individuals \& Where is the power to annul vested rights 8 It is certainly not to be found in the Constitution. True, the provision that no State shall pass any law inpairing the obligations of contracts applies only to State legislation. For such legislation the prohibition was necessary; for State legislatures have all legișlative power which is not expressly denied to them. But no necessity existed for imposing such a limitation on the power of Congress. As Mr. Hamilton says, in the eighty-fourth number of the Federalist, "Why declare that things shall not be done which there is no power to do "" * * * I search in vain for any express or implied grant of power to add new terms to any existing contracts made by or with the Government, or any grant of power to destroy vested rights. * * * And not only is such legislative authority not conferred upon Congress by the Constitution, but it is, in effect, expressly denied.

\section{EXECUTIVE DOCUMENTS HAVING REFERENCE TO THE QUESTION OF} TITLE.

[Senate Mis. Doc. No. 38,Forty-first Congress, second session.]

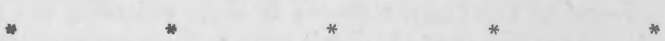

DePaRTMENT OF THE INTERIOR,

General Land OfFick, March 1, 1869.

SIR: In accordance with your request of the 27 th ultimo, that I furnish the Committee on Indian Affairs an estimate of the quantity of lands embraced within the limits of the Cherokee country west of the ninety-sixth degree of west longitude, south of Kansas, the area of the "Outlet," the quantity in the State of Kansas, and the character of the title by which said lands are held by the Cherokee Indian Nation, I have the honor to submit the following statement:

(1) The quantity of the Cherokee lands south of Kansas, between the ninety-sixth and ninety-eigth degreespof longitude west of Greenwich is 4,247,347 acres.

(2) Between the ninety-eighth and one hundredth degrees of longitude west of Greenwich is 4,247,347 acres. 
(3) In the State of Kansas a strip of about 2 miles in width, adjoining the south boundary of the State, and extending west from the Neosho River to the one hundredth meridian, 228 miles, is estimated to contain 368,640 acres.

The character of the title of the Cherokee lauds under the three foregoing heads, estimated to amount to $8,863,334$ acres, as well as that portion of their lands $80 u$ th of Kansas, and lying east of the ninety-sixth degree of west longitude, containin: an estimated area of $4,710,801$ acres, and aggregating the quantity of $13,574,13$ acres, was derived by patent in fee simple from the United States under date of December 31, 1831; by virtue of the provisions of treaties with the Cherokees of May 6, 1828; act of Congress of May 28, 1830; stipulations in treaty of February 14, 1833, and the second and third articles of treaty of December 29, 1835.

(4) The area of the "Outlet," which lies in Indian Territory between $100^{\circ}$ and $103^{\circ} 30^{\prime}$ of west longitude, contains 4,273,893 acres, and does not appear to be owned by the Cherokees.

I have, etc.,

\section{Jos. S. WILsoN,} Commissioner.

Hon. JAs. HARLAN, Acting Chairman Committec on Indian Affairs, V. S. Senate.

[Senate Ex. Doc. 124, Forty-sixth Congress, second session.]

* * The condition of the lands in what is usually denominated the Indian Territory is that of lands to which the ultimate fee is vested in the United States, but which, by treaty stipulations, statutory enactinents, and executive acts thereunder, have been set apart and reserved for the sole use and occupancy of certain Indian nations and tribes, so long as their national or tribal organizations are preserved. The boundaries of this section of country are defined only by the terms of the various treaties with these nations and tribes, and by the legislative action which has prescribed the limits of the contiguous States and Territories of the Union. Over it the public land system has never been extended, nor has any action ever been taken by Congress looking to its survey as public land. Much of it is held by four nations-the Choctaw, Chickasaw, Cherokes, and Creek-to whom patents have issued in accordance with the requirements of laws and treaties, and who exercise within their respective boundaries full control, subject only to such supervisory power by the United States Government as may be deemed necessary for the publio peace, and all attempts to induce Congress to erect it into a Territory of the United. States have heretofore failed.

This statement of the condition of the land is, I think, sufficient to show that even had the act of July 25, 1866, made a grant to the Atlantic and Pacific Railroad. Company of land in the Indian Territory the Department would be powerless to carry it into effect without further legislation, and for that reason the company's demand could not be complied with.

But, in addition, I think the demand can not be complied with for reasons that the company has no grant of lands in the Indian Territory, that, without entering upon the question of the intent of Congress to make a present grant of such lands, which I do not understand the company to claim, an ultimate grant, even, was not conferred by the act except as such grant might be acquired from the Indians by the company. (Report of Commissioner of the General Land Office, October 13, 1877.)

[Message, Senate Ex. Doc. No. 20, Forty-sixth Congress, first session, pp. 5, 6.]

In a letter to the Secretary of the Interior, April 19, 1879, in reference to an attempt made by citizens of the United States to enter lands in the Indian Territory west of lands occupied by the four civilized tribes, the Commissioner of Indian Affairs said (see copy with Choctaw papers):

"The lands in question were ceded to the Cherokee, Creek, Seminole, Chickasaw, and Choctaw Nations of Indians prior to 1836 , under solemn treaty obligations that they should be protected against the encroachments of the whites. The grants to them were fee simple, saving only that their lands were not to be conveyed except to the United States. By the treaties of 1866 with these tribes they ceded the lands under consideration in trust to the Government for the purpose of settling other Indians thereon, the tribes to be reimbursed from the proceeds of the sales of the lands as fast as such settlements were made.

"Under these provisions the Osages, Poncas, Pawnees, and Nez Perces have been settled within the Territory, but a large area remains undisposed of, in which the United States has only a trust interest, and over a large portion of which, by the treaty of 1866 , the Indians atill have jurisdiction. 
"While the language of the Cherokee treaty of July 19, 1866, varies somewhat in form from that of the treaties with the other tribes, the purpose to be accomplished. is the same in all. A certain rate per acre was to be paid for the lands ceded by each nation as fast as they were sold. Payment in full has not been made in accordance with the treaties. The lands have not all been settled by other Indians, and hence the trust has not been discharged." * * *

[Idem. pp. 13, 14.]

In replying to this letter the Secretary of the Interior, ander date April 25, 1879, wrote as follows:

* * * "By the intercourse act of June 30, 1834, this tract of territory, with others, was declared Indian country, and for its government the basis was created of the present intercourse laws as embodied in the Revised Statutes, sections "2111 to 2157. Since that period, although the boundary of the Indian country has been varied under the operation of numerous laws, the whole Indian Territory has beon regarded as Indian country, subject to no State or Territorial laws and excepted from judicial process, except under special enactments providing for a limited and restricted jurisdiction, for the purposes of which it has been, by section 533 , Re. vised Statutes, attached to the western district of Arkansas.

"None of the land or general laws of the United States have been extended to any part of the Indian Territory, except as to crimes and punishments and any other provisions regulated by the intercourse acts.

"This being the condition of things, it is clear that no authorized settlement could be made by any person in the Territo $v$, except under the provisions of the inter. course laws, such person having first obtained the permission provided for in those statutes.

"It may be further stated that no part of said Territory remains free from appropriation either to a direct trust assumed by treaty, or by reservation for tribes thereon under Executive order, except that portion still claimed by the State of Texas, and lying between Red River and the north fork of the same." (See the various treaties, agreements, and Executive orders from 1866 to the present time.)

[Senate Ex. Doc. 111. Forty-seventh Congress, first session. 'Letter of Secretary of Interior to Secretary of War, May 1, 1879, as to status of lands in Indian Territory.]

In a letter to the Secretary of the Interior, April 25, 1881, the acting commissioner for the General Land Office said:

"* * * Prior to 1866 the whole area of the Indian Territory, except a small portion in the northeast corner which belonged to the Senecas, Shawnees, and Quapaws, was embraced in the grants made and patented to the Cherokee, Choctaw, and Creek Indians, under the treaties with said tribes, respectively.

"The several treaties nnder which the title of the United States was conveyed to said tribes are as follows:

"Cherokee Treaties.-May 6, 1828 (7 Stat. 310); February 14, 1833 (7 Stat. 414); December 29, 1835 (7 Stat. 478).

Patent issued to the Cherokee Nation December 31, 1838.

"Articles 15 and 16 of the treaty with the Cherokees (14 Stat. 803, 804) provide that the United States may settle any civilized Indians, friendly with the Cherokees and adjacent tribes, within the Cherokee country, on unoceupied lands, on certain terms and conditions specified in the treaty.

"These provisions made the United States the agent of the Cherokees for the sale and disposal of unoccupied land in the Cherokee country for the benefit of said tribe, but restricted such sale and disposal exclusively to friendly Indians.

"In pursuance of the stipulations of the furegoing compacts, and in the exercise of the trusts assumed by the United States under the several treaties, and in accordance with specific provisions of law and the lawfil orders of the President, all the lands in the Indian Territory to which the United States has title have been permanently appropriated or definitely reserved for the uses and purposes named * * * ."

[Senate Ex. Doc. No. 54, Forty-eighth Congress, first session. Letter from Seoretary of Interier, January 12, 1884, transmitting, in compliance with Senate resulution of Deceinber 4 , 1883, copies of docu. ments and correspondence relating to leases of lands in the Indian Territory to citizens of the United States for cattle grazing and other parposes.]

(NOTE.-Those relating to Cherokee lands west of ninety-six degrees, will be found. on pp. 126-160.) 
[Senate Ex. Doc. No. 17, Forty-eighth Congress, second session.]

In a letter from the Secretary of the Interior, Jannary 3,1885 , transmitting, in answer to Senate resolution of December 3,1884 , report relative to the leasing of Indian lands in the Indian Territory, Mr. Secretary Teller said:

"The Cherokees have a fee-simple title to their lands, and they do not recogniz" the right of the Department to interfere in the management of their affairs with reference thereto. Patent was issued to this nation of Indians, December 31, 1838, for their lands in the Indian Territory, under the provisions of articles 2 and 3 of the treaty of 1835 ( 7 Stat. 428 ), and in accordance with the terms of the act of May 28, 1830 (Id. 412)." The Secretary then cites Holden $v$. Joy (17 Wall. 211), United State $v$. Ben Reese (5 Dill. 405), and Attorney-General Devens's opinion in Kansas school. land grant indemnity case (16 Opinions 430).

"The sixteenth article of the treaty of 1866 (14 Stat., 804) provides that:

" "The United States may settle friendly Indians in any part of the Cherokee country west of $96^{\circ}$ to be taken in a compact form, in quantity not exceeding one hundred and sixty acres for each member of said tribes thus to be selected, the boundaries of each of said districts to be distinctly marked, and the land conveyed in fee simple to each of said tribes, to be held in common or by their members in severalty, as the United States may decide, * * * the Cherokee Nation to retain the right of possession and jurisdiction over all of said country west of $96^{\circ}$ of longitude until thus sold and occupied, after which their jurisdiction and right of possession to terminate forever as to each of said districts thus sold and occupied.'

"The article does not change or modify the title of the Cherokees or vest any title in the United States to the lands west of ninety-six degrees. It simply gives the United States the right, with certain conditions to follow, to settle friendly Indians in that country. This is the country which is supposed to have been leased. Junge Parker, of the United States district court for the western district of Arkansas, in a letter of July 17, 1883, in answer to one addressed to him by one C. W. Rogers, says that 'if persons take cattle into their (the Indians) country to graze them, they (the Indians) have the right to collect a grazer's tax.'

"The Senate Committee on Indian Affairs, in a report made June 22, 1874, having had under consideration the petition of sundry citizens of Kansas remonstrating against the imposition by the Cherokee Nation of a tax upon cattle driven through their territory from Texas to northern markets, say, after quoting the ninth section of the act of June 30,1834, regulating trade and intercourse with the Indians, now section 2117 of the Revised Statutes:

" Now, this is conclusive in regard to that portion of the tax exacted for the privilege of grazing stock within the limits of the Cherokee reserve. The tax is within the amount of the penalty fixed by law for grazing stock without the consent of the nations, even though the stock should be kept upon their grazing land full three months. It only remains, then, to inquire into the legality of the tax imposed fore the right of way through the country. * * * (Senate Ex. Doc. 74, Forty-fifth Congress, second session, p. 2.)

"Under the decisions of the courts as to the title to which they hold their lands, and the guaranty pledged them by the United States in the sixteenth article of the treaty of 1866, can anyone question or doubt their right to make such a disposition of the grass growing on their lands as they have made, whether it is called a lease, license, or permit? The land is theirs, and they have an undoubted right to use it in any way that a white man would use it with the same character of title, and an attempt to deprive the nation of the right would be in direct conflict with the treaty as well as the plain words of the patent, They are quite capable of determining without the aid of the Interior Department or Congress, what is to their advantage or disadvantage, and the Government can not interfere with their rightful use and occupation of their lands, which are as rightfully theirs as the public domain is that of the United States, subject only to the provisions of Article XVI of the treaty of 1866, which at most is only a contract to sell certain portions of the land, but until the Government settles friendly Indians thereon and pays for the land, the right of possession and occupancy is especially reserved.

"It has been said that the permits or leases from the Cherokee Indians were obtained by fraud and corruption. On this subject the Interior Department has no information not possessed by the public at large. The fifth article of the treaty of 1835 with the Cherokees provides as follows:

"'The United States hereby covenant and agree that the lands ceder to the Cherokee Nation in the foregoing article shall in no future time, without their consent, be included within the territorial limits or jurisdiction of any State or Territory. But they shall secure to the Cherokee Nation the right by their national councils to make and carry into effect all such laws as they may deem necessary for the government and protection of the persons and property within their own country belonging to their people, or such persons as have connected themselves with them; Provided, 
alwoays, That they shall not be inconsistent with the Constitution of the United States, and such acts of Congress as have been or may be passed regulating trade and intercourse with the Indians; and also, that they shall not be considered as extending to such eitizens and Army of the United States as may travel or reside in the Indian country by permission according to the laws and regulations established by the government of the same.'

"Under the provisions of the treaty of 1835 the Cherokees adopted a constitution and organized a government, not on the plan of the former Indian government, but on a plan very nearly resembling that of the several State governments.. This constitution provides for an elective chief and the election of members of the council and house of representatives. By the provisions of the treaty of 1846 the Cherokees were recognized as a nation, and the Government stipulated with them that-

"Laws shall be passed for equal protection, and for the security of life, liberty, and property; and full authority shall be given by law to all or any portion of the Cherokee people peaceably to assemble and petition their own government, or the Government of the United States, for the redress of grievances, and to discuss their rights. All armed police, light horse, and other military organizations shall be abolished, and the laws enforced by the civil authority alone.

"No one shall be punished for any crime or nisdemeatror except on conviction by a jury of his country, and the sentences of a court duly anthorized by law to take cognizance of the offense. And it is further agreed all fugitives from justice, except those included in the general amnesty herein stipulated, seeking refuge in the territory of the United States shall be delivered up by the authorities of the United States to the Cherokee Nation for trial and punishment.'

"This was in consequence of some disorders that had arisen among the different bands of this tribe. The right of the Cherokee Nation to cuntrol its property is especially guaranteed by the provisions of Article vi of the treaty of 1835 and the subsequent treaties. This is especially the case in the treaty of' 1866 , as may be seen by the reference to Article Xvi of that treaty, wherein it is stipulated that the lands to be taken by the United States to settle friendly Indians on should be paid for at such price as the Cherokees and such friendly Iudians might agree on, subject to the approval of the President of the United States. The rights reserved to the United States are clearly expressed in the several treaties, and the right of the United States to control the Cherokee property and prevent the nation from having the full and absolute control of the products of these lands is not even suggested. On the contrary, the Government guarantees, in Article XXVI, as follows:

" "The United States guarantee to the people of the Cherokee Nation the quiet and peaceable possession of their country and protection rgainst domestic feuds and insurrections, and against hostilities of other tribes. They shall also be protected against interruptions or intrusion from all unauthorized citizens of the United States who may attempt to settle on their lands or reside in their territory. In case of hostilities among the Indian tribes, the United States agree that the party or parties commencing the same shall, so far as practicable, make reparation for the damages done.'

"The Department has not considered it the duty of the Commissioner of Indian Affairs or the Secretary of the Interior to interfere with the affairs of the Cherokee Nation, except in the case especially provided for by treaty with that nation.

"The title of the lands occnpied by the Osages, Kaws, Pawnees, Poncas, Nez Percés, Otoes, and Missourias, in the Indian Territory, is held by the United States in trust for such Indians, by deed from the Cherokee Nation. The Government is trustee without interest, and the Indians are the cestuis que trust, being the real owners of such land. But these Indians are not the tenants of the trustees and can not be dispossessed, because their right of occupation and use of the lands was fixed in the statutes ereating the trust; the United States is the naked trustee, and whatever the Indians might do with the fee in them they may do with the fee in the United States in trust for them, except to sell the lands. Some of the Indians named have bought and paid for their lands, and are entitled under the treaty with the Cherokees to a fee-simple title in theinselves. Their right to occupy and control the possession of such lands, and to receive the products thereof can not be questioned, and Congress can not interfere to prevent the cestuis que trust from having the usual and natural use of the lands so occupied by them. Any attempt to do so would be a confiscation of the lands."

[Senate Ex. Doc. No. 54, Forty-eighth Congress, second session. Senate Ex. Doc. No. 50, Forty-eighth Congress, second session. (Out of print, see copy sent in Choctaw case.)]

In transmitting a report of the Commissioner of Indian Affairs of January 26, 1885, in reply to Senate resolution of January 22, asking information as to the status of unoccupied lands in the Indian Territory, to the President, the Secretary of the In- 
terior (Hon. H. M. Teller), on the same date, wrote as follows, with reference to the lands of the Indian Territory:

"6* * * It is believed that there will be found at all times in the United States a wholesome public opinion that will demand of the Government that its contracts heretofore made with the Indians be respected in all cases where they do not conflict with the interests of the Indians and are not unjust to the people of the United States; but contracts or treaties impossible of execution, unjust and unfair to both whites and Indians, ought to be segregated or modified by legislative action. It is not beneficial to the Indians to have millions of acres of valuable land remain un. occupied around them.

"There is a general sentiment that these lands should not be withheld from settlement because they were included within the boundaries of the Indian Territory.

"These lands are desirable for agricultural and grazing purposes, and every year the difficulty of keeping them from settlement will increase. 'That they can be so maintained for any considerable length of time is hardly possible. Objection will be made to the occupation of any part of the Indian Territory by others than Indians, on the ground that the Government set apart the Territory for the exclusive use of the Indians, and covenanted that no others should reside therein. It is not denied that the treaties so provide. It is, however, within the power of the Government with the consent of the Indians interested, to change this provision of the treaties so that these desirable unoccupied lands may be placed within the lawful reach of settlers.

"Steps should be taken at once to change the present condition of affairs in the unoccupied portion of the Indian Territory. It can be done without the violation of the treaties or without subjecting the Government to the charge of bad faith. The power that made the treaties may in like manner abrogate or modify them. It is not proposed to despoil the Indians nor to compel them to accept less than the full value of whatever they surrender. It will not be wise to take an acre of this land needed by these Indians or by the coming generation of them; but the lands now owned by the Government for the purpose before mentioned may be opened to settlement with the consent of the civilized tribes, or segregated from the lands occupied and owned by the Indians, and then opened to settlement.

"However, until the existing status of the lands shall have been changed by agreements with the Indians interested, or in such other manner as may be determined upon by Congress, the integrity of the treaties heretofore made with the Indians should be maintained, and the power of the Government, to the extent necessary, should be exercised to keep intruders and all unauthorized persons off of the lands." (Sen ate Ex. Doc. No. 54, Forty-ejghth Congress, second session.)

\section{EXECUTIVE DOCUMENTS HAVING REFERENCE TO DISPOSITION OF} LANDS WEST OF THE NINETY-SIXTH DEGREE.

[Message, Senate Ex. Doc. No. 32, Forty-fifth Congress, second session.]

In a report made to the Secretary of the Interior, February 16,1878 , in reply to Senate resolution of January 30,1878 , calling for information respecting the status of lands in the Indian Territory, the Commissioner of Indian Affairs said:

"The Cherokees, by the sixteenth article of the treaty of July 19, 1866 (14 Stat., p. 799), ceded to the United States the authority to settle friendly indians on any part of their lands west of the ninety-sixth degree. 'These lands $(8,140,884$ acres), when so occupied by friendly Indians, are to be paid for to the Cherokees, at such price as may be agreed upon as stipulated in said sixteenth article.

"In accordance with this stipulation and an act of Congress approved June 5, 1872 (17 Stat., p. 228), the Kansas and Osage tribes of Indians were settled upon the tract of country lying between the Arkansas River and the ninety-six degrees, the Kaws occupying a tract of 100,141 acres and the Osages a tract of $1,466,167$ acres. The price paid for these two tracts was 70 cents per acre.

"By the fourth section of an act of Congress approved April 10, 1876 (19 Stat., p. 28), there was set apart for the use and occupation of the Pawnee Indians a tract of country comprising 230,014 acres out of the lands named in the sixteenth artiole of said Cherokee treaty, the price not to exceed 70 cents per acre. The Pawnees have been in possession of this reserve for several years, but no payment has been made to the Cherokees. The lands were appraised last year by a commission appointed under the fifth section of an act of Congress approved May 29, 1872 (17 Stat., p. 190), at an average valuation of 59.9 cents per acre. The remainder of the Cherokee lands west of the ninety-sixth degree (6,344,562 acres) is unoccupied, the United States not having as yet settled thereon any other tribes." 
[Message, Senate Ex. Doc. 26, Forty-sixth Congress, first session, pp. 1, 2.]

May 24, 1879, the Secretary of the Interior, in transmitting report of the Commissioner of Indian Affairs, in reply to Senate resolution of May 14, 1879, said:

"Since that report (see Ex. 1ooc. No. 32, Forty-fifth Congress, second session supra) the Ponca and a part of the Nez Perce tribes ha ve been located upon a portion of the Cherokee lands, with the consent of that nation, which is the only change in the condition of the Indians in said Territory.

"As stated by the Acting Commissioner it is the intention of this Department to observe fully the laws and treaties under which the country known as the Indian Territory was originally set apart for the permanent home of the Indian tribes who might be from time to time located therein.

"My letter of May 1, 1879, to the honorable Secretary of War, a copy of which formed a part of my report of the 10th instant, in answer to Senate resolution of May 7,1879 , will be found to set forth in full the history and occupation of said Territory for the purposes indicated."

[Senate Mis. Doc. No. 76, Forty-sixth Congress, second session.]

Letter of Secretary of Interior, April 20, 1880, inclosing opinion of Commissioner of Indian Affairs relative to proposed amendment to Indian appropriation bill advancing $\$ 500,000$ to Cherokee Nation on account of lands of theirs sold by the United States.

[Senate Mis. Doc. No. 77, Forty-sixth Congress, second session.]

Letter of Cherokee delegation, April 8, 1880, to chairman Senate Committee on Indian Affairs, inclosing amendment as above.

[Message, H. Fx. Doe. 54, Forty-seventh Congress, second session, pp. 35, 36, 37.]

In a report made to the Secretary of the Interior, February 17, 1882, upon the question of payment to the Cherokees for lands west of the ninety-sixth degree, under treaty of 1866, the Commissioner of Indian Affairs said:

(After reciting the sixteenth article of the treaty.)

"This article (sixteenth article, treaty of 1866) does not change or modify the title of the Cherokees to their lands west of the ninety-sixth degree, this provision of the treaty simply gives the United States the right to settle friendly Indians in that part of the Cherokee country, and provides that the Cherokees will sell to such Indians a portion of their country, the area to be fixed according to the number of Indians so settled, who were to pay the Cherokese for lands occupied at a price to be agreed upon by the parties in interest, and if they could not agree the President was to fix the price. Said article vests no title to these lands in the United States.

"In accordance with the stipulations contained in said sixteenth article, and the provisions of the act of Congress approved June 5, 1872 (17 Stat., 228), the Osage and Kansas tribes of Indians were settled upon the tract of country lying between the ninety-sixth degree and the Arkansas River, the two tribes together occupying $1,570,186.30$ acres, at 70 cents per acre, making an aggregate sum of $\$ 1,099,137.41$, which amount has been transferred on the books of the Treasury from the Osage fund to the credit of the Cherokees.

"It was a condition precedent to the relinquishment by the Cherokees of the right of possession of and jurisdiction over any of said lands that the same was to be sold snd oecupied.

"It is true that a portion of said lands were to be set apart by the treaty of 1867 for the Cheyennes and Arapahoes, but these Indians alleged that a mistake had been made and that the country set apart for them was not that which they understood they were to have, and therefore they declined to accept the terms of the treaty so far as they relate to the reservation thereby created.

"The Cherokees have never received payment from the Cheyennes and Arapahoes for these lands, and they have never been occupied by the last-named Indians, and therefore they have not been 'thus sold and occupied,' as contemplated by the sixteenth article of the Cherokee treaty of 1866.

"The treaty with the Cheyennes and Arapahoes did not affect the title thereto, and it remains the same as it existed prior to the said treaty.

"This view of the case appears to have been taken by Congress in the act of April 10, 1876 (19 Stat., 28), authorizing the sale of the Pawnee reservation in Nebraska, and the settlement of said Indians in the Indian Territory. The fourth section of this act, after describing the reservation thereby set apart for the Pawnees, provides "That the terms of the sixteenth article of the Cherokee treaty of July 19, 1866, shall be complied with so far as the same may be applicable thereto,' part of the lands 
set apart for the Pawnees being lands ceded to the United States by the Creek treaty of June 14, 1866, and the remainder being a portion of the Cherokee lands which by the treaty of 1868 the United States attempted to set apart for the Cheyennes and Arapahoes, and provided further 'that the sum to be paid to the Cherokees by the Pawnees for such quantity of the land herein described as may be within the limits of the Cheroke country west of the ninety-sixth meridian of west longitude shall not exceed seventy cents per acre.'

"The select conmittee of the Senate on the removal of the northern Cheyenne". etc., appear to have taken the sanie ground. The committee in their report, in speaking of the lands set apart for these Indians by executive order of August 10, 1869 , says that 'it was never intended to be more than a temporary abiding place for these tribes, where they were to stop until the United States could extingnish the claim of the Cherokees to the lands included in the treaties with the Arspahoes and Cheyennes.' (See Senate Report No. 708, Forty-sixth Congress, second session, p. 2.)

"Of the Cherokee lands west of the Arkansas River, the following dispos tions hawe been made, viz:

"Under the provisions of the act of Congress approved April 10, 1876 (19 Stat., 28), there was set apart for the Pawnees 230,014.04 acres, at 70 cents per acre, making $\$ 161,009.82800$.

"There has been assigned to the Poncas 101,894.31 acres, at 47.49 eents per acre, which amounts to $\$ 48,389.600^{7} 8$; to the Nez Perces $90,710.89$ acres, which, at the same price, amount to $\$ 43,078.60,1,05 ;$ and to the Otoes and Missourias, under the act of March 3, 1881 (21 Stat., 380), 129,113.20 acres, at 47.49 cents, equals $\$ 61,315.85 \frac{87}{81}$.

"Of the Cherokee lands west of the Arkansas River there has, therefore, leen assigned to friendly Indians 551,732.44 acres, at an aggregate value of $\$ 313,693.89,6{ }^{2} \sigma^{\circ}$.

"By the act approved June 16, 1880 (Pamphlet laws, p. 248), it is provided, "that the sum of $\$ 300,000$ is hereby appropriated, to be paid into the treasury of the Cherokee Nation, out of the funds due said nation for its lands in the Inclian Territory west of the Arkansas River, as per estimates of the Secretary of the Interior.'

"By the deficiency act of March 3, 1881 (21 Stat., 422), $\$ 50,000$ was appropriated for the purchase of 101,894 acres of land occupied by the Poncas in the Indian Territory. Of this amount $\$ 48 ; 389.46$ has been carried to the credit of the Cherokees, being at the rate of 47.49 cents per acre, the price fixed by the President, as before stated, making a total of $\$ 348,389.46$.

"The Cherokees have, therefore, received $\$ 38,595.70$ in excess of the amount due them for their lands west of the Arkansas River, which has been appropriated under the provisions of the sixteenth article of the treaty of 1866 . It may be proper to add, however, that the Cherokees still have, as the treaty provides, the possession and jurisdiction of all lands except those assigned as above stated, and have been and are now receiving rents from the same."

[Senate Fix. Doc. No. 19, Forty-sixth Congress, second session.]

Letter of the Secretary of the Interior, January 3, 1885, transmitting, in answer to Senate resolution of December 23, 1884, report of Commissigner of Indian Affairs regarding the price paid and appraisement made of Cherokee lands west of Arkansas River.

\section{REPORTS OF COMMITTEES.}

[Senate Journal, Fortieth Congress, third session, Fobruary 13, 1869.]

Mr. Doolittle, from the Committee on Indian Affairs, to whom was referred the joint resolution (H. Res. 335) far the protection of settlers on the Cherokee neutral lands in Kansas, reported it without amendment, and that it ought not to pass; and also submitted a report (No. 224) thereon as follows:

[Senate Report 224, Fortieth Congress, third session.]

The Committee on Indian Affairs, to whom was referred House Resolution 335, having had the same under consideration, report:

(1) That in their opinion the title to the lands in question, prior to the treaty of 1866, was in the Cherokee Nation as purchasers, and held by patent of the United States in fee simple.

(2) That no person had any right, legal or equitable, to enter upon such lands and claim adversely to that people.

(3) That the only settlers who can claim any legal or equitable rights in said lands adverse to the Cheroke Nation or their assignees are those provided for in the treaty of 1866 and the treaty supplementary thereto of 1868.

Therefore, the committee report in favor of an indefinite postponement of said resolution. 
[Senate Report No. 64, Forty-eighth Congress, firgt session-]

January 22, 1884, the Senate Conmittee on Indian Affairs, in reporting upon sundry petitions to Congress, praying that the Oklahoma lands be opened to settlement, after citing the letter of the Secretary of the Interior of April 25, 1879, supra, said:

$66 *$ * It will be seen by this letter from the Secretary of the Interior that the present legal status of the Oklahoma lands is that they are reserved by treaty stipulations for the purpose of settling Indians and freedmen thereon. The fact that no other disposition of them can be made except in violation of the treaty stipulations is, in the opinion of your committee, a sufficient objection to granting the prayer of the petitioners."

[House Report No. 2857, Fiftieth Congress, first session, July 11, 1888.]

Report of Committee on Territories on bill (H. R. 10614) to organize the Territory of Oklahoma, in which and in the minority report presented by Mr. Barnes, p. 16, otc., the title to the outlet lands is fully discussed.

\section{MISCELLANEOUS LEGISLATION.}

[Act March 3, 1885, 23 Stat., 384.]

SEC. 8. That the President is hereby anthorized to open negotiations with the Creeks, Seminoles, and Cherokees for the purpose of opening to settlement under the homestead laws the nnassignen lands in said Indian Territory ceded by them respectively to the United States by the several treaties of August eleventh, eighteen hundred and sixty-six, March twenty-first, eighteen hundred and sixty-six, and July sineteenth, eighteen hundred and sixty-six; and for that purpose the sum of five thousand dollars, or so much thereof as may be necessary, be, ind the same is hereby, eppropriated out of any money in the Treasury not otherwise appropriated; his action hereunder to be reported to Congress.

*

*

*

*

[Act February 8, 1887, 24 Stat., 388.]

AN ACT to provide for the allotment of lands in severalty to Indians on the various reservations, and to extend the protection of the laws of the United States and the Territories over the Indians, and for other purposes.

SEC. 8. That the provisions of this act shall not extend to the territory occupied by the Cherokees, Creeks, Choctaws, Chickasaws, Sewinoles and Osage, Miamis and Peorias, and Sacs and Foxes, in the Indian Territory.

[Act March 2, 1889, 25 Stat., 1005.]

SkC. 14. The President is hereby anthorized to appoint three commissioners, not more than two of whom shall be members of tho same political party, to negotiate with the Cherokee Indians and with all other Indians owning or claiming lands lying west of the ninety-sixth degree of longitude in the Indian Territory for the cession to the United States of all their title, claim, or interest of every kind or character in and to said lands, and any and all agreements resulting from such negotiations shall be reported to the President and by him to Congress at its - next session, and to the council or councils of the nation or nations, tribe or tribes agreeing to the same for ratification; and for this purpose the sum of twenty-five thousand dollars, or as much thereof as may be necessary, is hereby appropriated, to be immediately available: Provided, That said Commission is further authorized to submit to the Cherokee Nation the proposition that said nation shall cede to the United States, in the manner and with the effect aforesaid, all the rights of said nation in said lands upon the same terms as to payment as is provided in the agreement made with the Creek Indians of date January nineteenth, eighteen hundred and eighty-nine, and ratified by the present Congress; and if said Cherokee Nation sluall accept, and by act of its legislative authority duly passed, ratify the same, the said lands shall thereupon become a part of the public domain for the purpose of such disposition as is herein provided, and the President is authorized, as soon thereafter as he may deem advisable, by proclamation open said landś to settlement, in the same manner and to the same effect as in this act provided concerning the lands acquired from said Creek Indians, but until said lands are opened for settlement by proclamation of the Presi-

$$
\text { S. Rep. } 281 \longrightarrow-4
$$


dent no person shall be permitted to enter upon and occupy the same, and no person violating this provision shall be permitted to enter any of said lands or acquire any right thereto.

[Act May 2, 1890, 26 Stat., 81.]

AN ACT to provide for a temporary government for the Territory of Oklahoms, to enlarge the juris diction of the United States court in the Indian Territory, and for otber purposes.

Sec. 1. * * * Whenever the interest of the Cherokee Indians in the land known as the Cherokee Outlet shall have been extinguished, and the President shall make proclamation thereof, said outlet shall thereupon and without further legislation become part of the Territory of Oklahoma.

[Act August 19, 1890, 26 Stat., 356.]

* * To enable the Secretary of the Interior to continue the Cherokee Commission provided for by act approved March second, eighteen hundred and eighty" nine, twenty thousand dollars.

[Act February 28, 1891, 26 Stat., 794.]

AN ACT to amend and further extend the benefits of the act approved February eighth', eighteen hundred and eighty-seren, entitled "An act to provide for the allotment of land in severalty" to Indians on the various reservations, and to extend the protection of jthe laws of the United States over the Indians, and for other purposes.

Swc. 5. * * * Provided, That the provisions of this act shall not be held or construed as to apply to the lands commonly called and known as the Cherokee Outlet.

[Aot Marcb 3, 1891, 26 Stat., 1008.]

* * To enable the Secretary of the Interior to continue the Cherokee Commission provided for by act approved March second, eighteen hundred and eighty. nine, fifteen thousand dollars. 


\section{APPENDIX 3.}

[American State Papers, vol. 2, p. 125. Address of President Jefferson to deputies of the Cherokees of the Upper and Lower Towns, January 9, 1809.]

(For material portion of this, see preamble to treaty of July 8, 1817, 7 Stat., 156.)

[American State Papers, vol. 2, p. 103. From Gen. Jackson to Secretery of War, October 18, 1816 ]

* * * The Cherokees, as I believe, will make a tender of their whole territory to the United States for land in the Arkansas west of the Mississippi. A council is to be held shortly at Willstown, probably to select proper persons to explore that country and report its situation, etc. As soon as that is done, a delegation will be sent to the President to effect the exchange. * * *

[Idem, p. 103. From Geo. Graham, acting chief clerk War Department, to Gen. Jackson in reply. October 26, 1816.]

* * * Whenever the Cherokee nation shall be disposed to enter into a negotiation for an exchange of the lands they now occupy for lands on the west side of the Mississippi, and shall appoint delegates clothed with full authority to negotiate a treatyfor such exchange, they will be received by the President, and treated with on the most liberal terms.

[Idem, p. 479. From letter of Secretary of War (Calhoun) to Governor MeMinn, July 29, 1818.]

* * The President, in order to add as much as possible to the permanent prosperity of the Cherokees on the Arkansas, has given them an indefinite outlet to the west, which will continue their independence as long as is practicable.

[Idem, p. 483. Governor McMinn to Secretary Calhoun, Japuary 26, 1819.]

* * The Cherokee country east of the Mississippi is estimated by the best calculations to contain upwards of $14,000,000$ acres, a great proportion of which is rich land and well watered, particularly in the Alabama territory, which certainly contains the most valuable part of the Cherokee country.

[Secretary of War to chiefs of the Arkansas Cherokees.]

DEPARTMENT OF WAR, October $8,1821$.

Brothers: I have received your communication of the 24th of July last, complaining that the promises of the Government in relation to intruders upon your lands and to an outlet to the west have not been performed. It has always been its intention to carry into effect fully every promise made to you, and which I was under the impression had been done, particularly upon the points complained of, as orders were issued some time since for the removal of the whites from your lands and from the tract of country to the west of your reservation, commonly called "Lovely's Purchase," by which you would obtain the outlet promised. Copies of these orders are herewith inclosed for your information.

Governor Miller, who is now here, on his return to the Arkansas Territory, informs me that he knows of but one person who has settled upon your lands, and he believes that person resides there with the nermission of the nation.

$\mathrm{He}$ is, however, authorized to cull the attention of Maj. Bradford to the orders above referred to, and if they should not have been previously carried into effect to request him to do so without further delay. It is to be always understood that in removing the white settlers from Lovely's Purchase for the purpose of giving the outlet promised you to the west, you acquire thereby no right to the soil, but merely to an outlet, of which you appear to be already apprised, and that the Government reserves to itself the right of making such disposition as it may think proper with regard to the salt springs upon that tract of country.

Governor Miller is also fully authorized to receive and adjust any other complaints you may have to make, which it is believed can be done satisfactorily by him upon 
the spot, without your sending a deputation for that purpose, as you express a wish to do. If, however, he should find any difficulty in the business and think it of sufflcient importance for you to send on a delegation, he is vested with discretionary power to grant you power to send one in the spring.

I understand that some of your nation have settled to the south of the Arkansas River on our lands, and as it is equally improper for your people to occupy our lands as for our people to occupy yours, it is expected that you will immediately order all your people to remove from the south to the north side of the river within the limits of your reservation; which, if not done in a reasonable time, Governor Miller is instructed to take the necessary measures to effect.

I remain your friend and brother,

\section{J. C. Calhoun.}

References to American State Papers, Indian Affairs, vol. 2, pp. 116, 130, 465, 47,9, 480, 483, 485, 542,543, contained in letter of $R . L$. O. to D. \& H., October 15,1891

\section{, [A merican State Papers, vol. 2, p. 116.]}

[Extract from letter of Agent R. J. Meigs to Secretary of War, dated Cherokee Agency, November 8, 1816.]

* * * They (the Cherokees) find that pressure on them for cessions of land will probably be soon made from Tennessee, South Carolina, and Georgia, and aithough they can, in the first instance of the application, say no, at the same time they feel they can not long resist reiterated applications, and they anticipate that in this way their limits will be circumscribed. And this is not all they have to fear, for many of them will emigrate to the west, land or no land, and in this way they will crumble to pieces and their identity as a nation will be lost, to prevent which it is clear to me they must exchange their land here for land west of the Mississippi River; there they may preserve their national existence to some more remote period. They are aware even if placed on the west of Arkansas that they must probably make cessions of land to the United States in that country, but they presume they shall be less pressed on that subject there than here, and to guard against, or rather to provide for such a contingency, it has becn suggested to me by an intelligent Cherokee that in allotting a tract of land for them on Arkansas River it would be well for them, and no damage to the United States, to have only three definite lines drawn to designate such allotment, leaving the boundary westward open as a wilderness, so as they make cessions on the east side they may make proportionate advances on the west. * * *

[Idem., p. 130.]

Treaty with Cherokees of July 8, 1817.

[Idem., p. 465.]

Correspondence in relation to extinguishment of title of Cherokees to land in Georgia (1822-'23.)

[Idem., pp. 479, 480, 485, Secretary of War to Governor MoMinn, July 29, 1818.]

* * * The President, in order to add as much as possible to the permanent prosperity of the Cherokees on the Arkansas, bas given them an indefinite outlet west, which will continue their independence as long as it is practicable.

[Idem., pp. 542, 543, message of President Monroe to the Senate, January 27, 1825. Plan for removing the several Indian tribes west of the Mississippi River.]

(See executive papers No. 64, Eighteenth Congress, second session, post infra.)

[Ex. papers No. 64, Eighteenth Congress, second session, p. 3.]

In his message to Congress, January 27, 1825, President Monroe said:

"6** * The great object to be accomplished is the removal of those tribes to the territory designated on conditions which shall be satisfactory to themselves and honorable to the United States. This can be done by conveying to each tribe a good title to an adequatetortion of land to which it may consent to remove, and by providing for it there a system of internal government which shall protect their property 
from invasion and by the regular progress of improvements and cirilization prevent that degeneracy which has gensrally marked the transition from the one to the other state. ***"

[Idem., pp. 8, 10, 11.]

In report to President, dated January 24, 1825, Secretary Calhoun said:

"** * It is believed that the Cherokees, to whom has been allotted a country lying between the Arkansas and White rivers, will very readily agree to removing their eastern boundary further west on the consideration that for the lands thereby ceded they may have assigned to them an equal quantity further west, as they have evinced a strong disposition to prevent the settlement of the whites to the west of them * * *. A sufficient country should be reserved to the west of the Cherokees, on the Arkansas, as a means of exchange with those who remain on the east. ***

"There is another point which appears indispensable to be guarded in order to render the condition of this race less afflicting. One of the greatest evils to which they are subject is that incessant pressure of our population, which forces them from seat to seat, without allowing time for that moral and intellectual improvement for which they appear to be naturally eminently susceptible. To guard against this evil so fatal to the race there ought to be the strongest and the most solemn assurance that the country given them should be theirs as a permanent home for themselves and their posterity without being disturbed by the encroachnent of our citizens.

[Senate Ex. Doc. No. 2, Twenty-second Congress, second session, pp. 37,38.]

In an address to the Cherokees east of the Mississippi, April 17, 1832, Secretary Cass said:

"**** The President is willing to enter into an agreement for your removal west of the Mississippi upou the following general principles:

"(1) That a country, sufficiently extensive and fertile, shall be distinctly marked out west of the Territory of Arkansas for you and your brethren where they now are.

"(2) That this country shall be conveyed to you by patent, under the provisions of the act of Congress of May 28, 1830, and that it 'shall be forever without the boundary of any State or Territory."

March 16, 1835, President Jackson, addressing the Cherokees east of the Mississippi River, said:

"* * * A number of your brethren, who have been delegated by that portion of your people favorable to emigration, have repaired to this place in the hope of being able to make some arrangement which would be acceptable to the Government of the United States and which would meet your approbation. * * * The whole subject has been taken into consideration and an arrangement has been made, which ought to be, and I trust will be, entirely satisfactory to you. The Senate of the United States have given their opinion of the value of your possessions, and this value has been insured to you in the arrangement which has been prepared. * * * The stipulations contained in this instrument (treaty, March 14, 1835) are designed to $* *^{*}$ lay the foundation of such social and political establishments in your new country as will render you a happy and prosperous people. * * * The United States have assigned to you a fertile and extensive country, with a very fine climate adapted to your habits, and with all the other natural adrantages which you ought to desire or expect.

"I shall, in a short time, appoint commissioners for the purpose of meeting the whole body of your people in council. They will explain. to you more fully my views and the nature of the stipulations which are offered to you.

"These stipulations provide, first, for an addition to the country already assigned to you west of the Mississippi, and for the conveyance of the whole of it by patent in fee simple, and also for the security of the necessary political rights, and for preventing white persons from trespassing upon you. * * * There are 13,000,000 acres convered to the Western Cherokees and yourselves by former treaties, and which are destined for your and their permanent residence, so that your whole country west of the Mississippi will contain not less than 13,800,000 acres."

[Senate Doc. No. 1, Twenty-fourth Congress, first session, p. 25.]

In his message to Congress, December 7, 1835, President Jackson said :

"** * * The pledge of the United States has been given by Congress that the country destined to be the residence of this people shall be forever 'secured and 
gaaranteed to them.' A country west of Missouri and Arkansas has been assigned to them into which the white settlements are not to be pushed. No political communities can be,formed in that extensive region, except those which are established by the Indians themselves, or by the United States for them and with their concurrence." * * *

\section{TREATY OF DECEMBER 29, 1835.}

[Senate Ex. Doc. 120, Twenty-fifth Congress, second session, p. 98 . From memorandum delivered by Secretary of War to Senator King, of Georgia, February 28, 1835.]

Besides these pecuniary stipulations a tract of very valuable land, estimated to contain about 800,000 acres, west of the Mississippi, is to be added to the territory already possessed by them (this territory originally contained abont $7,000,000$ acres), in addition to which they were entitled to the use of another tract, containing about $6,000,000$ acres, for the purpose of an outlet of communication with the tribes and country west of them. It is proposed in the arrangement with Ridge and his party to grant them the entire property of this tract of 6,000,000 acres for their unconditional use; this will make, for the whole country given and proposed to be given to them west of the Mississippi, 13,800,000 acres of land.

[Idem, p. 139. Letter of Seoretary of War to chairman House Committee on Ways and Means, June $15,1836$.

War Department, June 15, 1836.

Sin: Application has been made for a patent to be granted to the Cherokees, under the third article of the treaty recently concluded with them. There are two tracts of land to be included in the patent and each has been partially surveyed, though, it is thought, not sufficiently so to enable the proper office to describe them with proper precision in a patent. The lines of the large tract have not actually been closed, and the Quapaws have a reservation which probably runs into the small tract and which may require a deduction to be made from the price which was charged to the Cherokees for the latter.

Under these circumstances I have the honor to submit an estimate for the consideration of the Committee of Ways and Means, to enable the Department to have these surveys completed so that the patent which the Cherokees are anxious to receive may be issued without unnecessary delay.

As it is difficult to ascertain here with precision the steps necessary to be taken, I propose to commit the superintendence of the matter to the Rev. Mr. McCoy, who is well acquainted with the topography of that region and who has been employed in surveying portions of it. An estimate of the sum deemed necessary for his compensation is added to the probable actual expenses of surveying. The surveys will be executed by competent persons under his direction.

Very respectfully,

Hon. C. C. Cambreming,

Lewis Cass.

Chairman Committee on Ways and Means, House of Representatives.

[Idem, p 144. Commissioner of Indian Affairs to Isaac McCoy, July 5, 1836.]

War Department, OfFice Indian AFFatrg, July $5,1836$.

Sir: By treaty of New Echota, of December 29, 1835, it is stipulated that the lands ceded to the Cherokees west of the Mississippi shall be secured to them by patent; and it appearing that the surveys of these lands have not been so far executed as to enable the Government to issue a patent, you are hereby appointed and instructed to cause the surveys of the said lands to be completed, and to supply every deficiency connected with the subject at this time, to prevent the issuing of a patent.

For information respecting the boundaries required, you are referred to the treaty itself. You will be careful to see that the requirements of that instrument, in relation to boundaries, are fully met.

You will appoint a competent surveyor to run and mark the lines which have not been surveyed, and allow him the same compensation as has heretofore been allowed for surveys of other Inctian boundary lines in that region; and to enable you to ietermine what remains to be done, you will be furnished with the field notes and plats of the surveys which have been Inade, so far as you are not at present in possession of them. It is understood that you are wanting the following, that is to 
say, the field notes and plats of the lines, from the mouth of the North Fork of the Canadian River to the Arkansas River, of the meanders of Arkansas and Verdigris rivers, of the line from the Verdigris to the point called for in the treaty, 25 miles north of Arkansas, and of the line from that point west, as far as the line has been run.

The acting superintendent of the Western Territory has been instructed to cause a survey of the lands of the Senecas and Quapaws. You will need his field notes of the survey of the Neosho, so far as that river divides their lands from those of the Cherokees, and as it is possible that the lands of the Quapaws may extend further north than the sonthern limit of the tract cederl to the Cherokees by the last clause of the second article of the treaty, and thereby diminish its quantity, the surveyor of the Seneca and Quapaw lands will be instructed to furnish you with a copy of the fiell notes and plats of his entire surveys as soon as they shall be completed.

It is expected that you will furnish the Department with field notes and plats of all the survess that you shall cause to be marle, and also with a duplicate plat of the whole tract provider by the truaty (one being for the use of the Cherokees), or duplieates of each, should their lands necess:urily form two tracts.

Aceompanying your plat of the whole you will furnish a statement of the conrae ancl distance of each line and the character of the object that terminates it; the names of the water courses, so far as they form boundaries, and the number of acres contained in the whole tract, if the land be included in one, or of each tract if it be in two.

The lands under consideration extend west as far as the limits of the United States territories. It is believed that in an open country so uncommonly favorable to correct measurement as that throngh which these surveys are to be made the western limit can be obtained with sufficient accuracy without celestial observations. Such mineralogical and geological observations will be made as can be done without hindrance to the principal work.

The commanding officer at Fort Leavenworth will be in ' lleted to furjish, at your request, such an escort as shall be sutti ..... for the protection of the surveying party against marauding parties of Indians.

You will enter upon this work immediately, and report its complotion to this office as soon as possible, and throughout the whole you will observe the most rigid eeonomy.

The appropriation for this business is $\$ 7,000$, and this amount will in no event be exceeded. Your own compensation will be at the rate of $\$ 8$ per day, to include your expenses for the time actually employed, to be paid on your certificate of honor. Your accounts will be accompanied by the requisite vouchers, according to the regulations of the Department.

You are authorized to draw on this Department for suc.' sums as may be necessary to enable you to fultill these instructions.

Very respectfully,

Rev. IsaaC McCoy,

C. A. HARris.

Now in Washington.

[Idem, p. 359. Letter from John Ridge to Secretary of War, Maroh 13, 1835.]

Wa shington City, March 18, 1835.

DEAR SIR: Before I leave this place for my native land, I wish to make a few suggestions in relation to the mode which onglit to be pursued in presenting the treaty for the ratification of the Cherokee peopls Wu, as a people, have been unanimous in opposition to a treaty. Now, as $\bar{I}$ believe, there is a majority for a treaty, and the difficulty is as to such a one as will be acceptable to the majority. The Ross party will desire to make one with the Government which will administer to their pride as well as profit, and will try to mislead the understandings of the poor ignornat Indians, and for a while may well succecd, but time, in the end, will dissipate those impressions.

In the first place, the President should send, through his commissioner, a friendly written adrlruss to the prople, as their political father, who entertains the greatest regard for the luture happiness of the Cherokees, as a community which is to exist under the protection ot the United States, with the right of exercising government over its people. To effect that object it was necessury they should have a home, a country which at no futare time should be encroached upon by State intrusion. That this home, in order to answer the purposes of an asylum, not only comfortable for the presest generation, but looking to their increasinu prosperity, he had enlargerl in this treaty, which he now proposes to their cousicleration, and for the purpose of defraying the expenses of their government and to promote civilization and religion he had also granted and vested sufficient funds for national purposes, the proceeds of which were subject to their own management. So well convinced was he that the 
Cherokees must have a country, and the funds to render them respectable as a nation, that ho never would change or lessen the extent of the one or reduce that of the other.

I am, sir, respectfully, your friend and brother,

The SECRETARY OF WAR.

JOHN RIDGE.

[Idem, pp. 456 and 457. Rel of proceedings of conncil held at Running Water, July 20, 1835. Commissioner Selucrmerhor:'s acidiess to the Cherokees.

Articles 2 and 3 declare that you are to have $\$ 4,500,000$ in money, to be paid as stipulated in the fuilowing articles, and $80 x, 000$ acres of land, in udulition to the lands already secured to the Cherokee Nation in the treaties with the Cherokeer west, and that this is to be in full for all your lands east of the Mississippi and your claims upon the United States. The whole quantity of lands you will now have west secured by this and other treaties will be $13,800,000$ acres, which is more than all the lands the whole Cherokee Nation owned before the treaty with Gen. Andrew Jacksou in 1817, by which they were to have acre for acre for their lands east of the Mississippi. I say you will have more land than you had there, for by that treaty you sold to the United States about $4.000,000$ acres, and you still own here about $7,000,000$ acres, making in all $11,000,000$ acres, so that without the 800,000 acres which you buy by this treaty you will have 2,000,000 acres more west of the Mississippi than you had here before the treaty of 1817.

The fourth article declares that all your lands west shall be secured to you by a patent deed from the President of the United States; and you will hold it by the same title the white man holds his lands as long as you exist as a State and reside upon it. * * * Article 6 secures your political rights; and declares that your country, without your consent, can not be included within the limits of any State or Territory of the United States; that you shall, in your national councils, make your own laws and regulations to govern all the persons and property in your country belonging to your nation in any way: Provided, They shall not be inconsistent with the Constitution of the United States and such acts of Congress as relate to trade and intercour'se with the Indians. These privileges you never can enjoy here, and without them you cease to exist as a nation.

[Idem, p, 491. Letters fiom Maj. Ridge and others, chiefs, to President Jackson, December 1, 1835.]

* * * We are among those who look to the time when the two portions of the Cherokee people shall be reunited under such a treaty basis as will promote the happiness and prosperity of the whole nation. Those bases mnst be such as the President has already recommended and urged, viz, the removal of the Cherokees to the lands allotted for them west of the Mississippi; the guaranty of those lands to them and their descendants by a patent; protection in their political rights and privileges, and the security and proper appropriation of such amount of the avails of the land here as may be necessary to promote the advancement of the Cherokee people in education, religion, and morals, and in all those things which adorn a virtuous and intelligent community.

[Idem, p. 672. Letters to Gen. Wool from President Jackson, September 7, 1836.]

* * * You will therefore make known to the Cherokee people that no alteration in the treaty will be made, but that all its terms and conditions will be faithfully and fully executed. * * *

[Idem, p. 675. Notice to the Cherokee people from Gen. Wool, September 19, 1836.]

\section{Headquarters Army E. T. and C. N.,} Red Clay, Tenn., September 19, 1836.

I am instructed by the President of the United States to make known to the Cherokee people that no alteration will be made in the late treaty entered into with chiefs and headmen of the Cherokee Nation, and ratified the 23d of May, 1836, by the Senate of the United States; and that the same in all its terms and conditions will be faithfully and fully execnted. Agreeably, therefore, to its terms, the Cherokee people are to emigrate in two years from the ratification of the treaty, and will be ouliged to go within that period.

To the Cheproken Paople, 
[Idem, p. 745. Report of Surveyor McCoy to Commissioner of Indian Affairs, December 15, 1836.]

I am sorry to inform you that with the utmost of my efforts I have not been able to have the survey of the Cherokee Indian lands completed.

(Assigns as reasons, delay in furnishing military escort, lateness of season, state of weather, condition of roads, etc.) * **

For the present it may be assumed that unless inaccuracies have occurred in the surveys from which I have made mx calculations, which I believe has not been the case, the Cherokees will obtain the full quantity of land stipulated for.

[Idem, pp. 950, 951, and 952. Report from Snrveyor McCoy to Commissioner of Indian Affairs, Sep tember 20, 1837.]

\section{WESTPORT, JACKSON COUNTY, MO.,} September 20, $183 \%$.

Str: By your instructions of July 5, 1836, I was required to cause the surveys of the Cherokee lands to be completed and to supply every deficiency connected with the subject which at that time prevented the issuing of the patent.

The surveys have been completed, the field notes of which are herewith respectfully submitted, together with duplicate plats of esch tract of Cherokee land, also a summary description of the boundaries, and the quantity of acres embraced therein.

The surveys being made agreeably to the requisition of the treaty necessarily divides the Cherokee lands into two distinct tracts, the northeast corner of the one epproaching the southwest corner of the other, within a distance of 30 chains. This intervening tract is a slip of unappropriated land lying north of the Quapaws, 1 mile 45 chains and 50 links wide, and extending from the Neosho River, the place where the two Cherokee tracts approach euch other, east 25 miles 36 chains and 56 links, to the western boundary of the State of Missouri, containing 24,813,039 acres (8ic),

'l'he second article of the Cherokee treaty provides that if the salt plain at which the Indians of the various tribes procure salt "should fall within the Cherokee lands, the right should be reserved to the United States to permit other tribes of red men to get salt on said plain in common with the Cherokees."

It appears there are two noted places at which the Indians, from time immemorial, have collected salt. One is on the Cherokee lands. It is a plain on which salt is formed by solar evaporation. situated on the salt fork of Arkansas River, about 15 or 20 miles south of their northern boundary and about 220 miles west of the State of Missouri.

The other is said to be a salt rock. It is on Creek lands, 8 or 10 miles south of the southern boundary of the Cherokee lands and about 200 miles west of the State of Arkansas.

The surveyor was unable to visit either of these places; but Osage Indians, who were hunting in the vicinity at the time he passed, pointed out to him the location of both.

Notwithstanding the Cherokee lands are divided into two separate tracts, the second article of the treaty requires both to be included in the same patent.

The fifth article of the treaty requires that the laws which the Cherokees may enact shall be consistent "with such acts of Congress as have been or may be passed regulating trade and intercourse with the Indians." Also, the third article stipulates that the patent to be issued shall be "according to the provisions of the act of May 28, 1830." This act provides that the lands patented "shall revert to the United States if the Indians become extinct or abandon them."

Therefore, while it is required that a patent should secure the lands to the Cherokees and their heirs and successors, it provides that it withholds from them the right to convey the same to other Indians.

To this matter I beg leare to solicit particular attention. It is the hinge upon which turns the weal or woe of all the tribes for which the Government is making provision in this Indian Territory, and vitally affecting the benevolent design of the Government in securing to the tribes the possession of their lands.

If the conveyance be made in terms which could hereafter, by possibility, be construed to authorize the Indians, either collectively or individually, to convey the whole, or any portion thereof, to others than Indians, either forever or for a limited time, white residents would be introduced and the Indian crowded out.

Last winter four chiefs of the Delaware Nation, professing to act by authority and in behalf of the whole, were induced to petition the Government for permission to lease to a certain white man (a citizen of the United States) and his children one section of land. I mention this fact, known to yourself, as an evidence that between the citizens of the United States and the Indians negotiations have already been commenced by which the former hope to obtain a footing within the Indian Territory.

In issuing the patent it will be necessary to do more than to guard against selling and leasing. These two avenues to the ingress of white populatiou being effectually 
barred, a third will be sought under the pretext of being employed to perform some useful service for the Indians. If an Indian be allowed to introdues a white man into the Indian country as a partner in business, as a clerk, as a laborer, as a physician, or in any capacity whatever, indulgence will be abused by avaricious individuals, or companies of Indians will be hired to form either nominal or real contracts for the introduction of white men, under the name of employes of the former.

None of the tribes are capable of guarcling their own interests, and if they were, in such transactions as these under consicleration human naturé should not be supposed' to be beyond the influence of the temptations of money. The right of introducing into the Indian country any white persons, citizens of the United States or of any other country, can never be safely possessed by any of the tribes until their condition becomes so improved that they can mingle with the white men without inconvenience.

In the present condition of the tribes, this subject is guarded by laws of Congress, but if the right to the soil be conreyed to the Indians by patent, without reserving in the same instrument their right of connecting white men with them in the occupancy of the land, the power of Congress subsequently to forbid it by law may well be doubted.

This subject acquires importance from the following facts, which $I$ hope will apologize for the earnestness with which I respectfully press its consicleration, namely, the case of the Cherokees, now under consideration, is the first that has occurred of issuing a pacent to an Indian tribe. The whole or portions of twenty-three tribes are already within this Indian Territory. In all probability the number of tribes will soon exceed thirty. The patent now to be issued will be quoted as a precedent for the future, and no tribe will be content with less authority than is granted to the Cherokees. But irrespective of other tribes, the introduction of white men into the Cherokee country alone would prostrate the designs of the Government to render the Indians secure in their possessions; for the Cherokee lands, embracing in the whole more than $14,000,000$ acres, extend from the east to the west of the country designed for Indian settloment and divide in two.

We can not consietently plead, in this case, that if the Indians choose to introduce white men into their country to their own destruction the fault will be theirs, not ours. The same might have been pleaded heretofore in relation to the laws for the preservation and welfare of the Indian tribes. Justice toward a very large majority of them, who are incompetent either to understand or take care of their ow $n$ interests, and humanity tow ard the whole, requires that our Government continne its guardianship.

By the prohibition above alluded to, no inconvenience could arise to any Indians whose circumstances require the assistance of white men. The matter being under the control of the Government of the United States, its laws regulating intercourse with the Indian tribes could always be such as to provide for the emergency. Laws providing for the temporary residence of white men in the Indian eountry either, for the benefit of the Indians or the Government of the United States, can be amended or repealed whenever their provisions are found to be exceptionable, but the patent under consideration will be unalterable. Of this I presume the Government will be fully aware, and will guard against wiles which afterwards it would be unable to remedy, and which would produce a failure of the experiment so auspiciously entered upon by the Government for the improvement of the condition of this hitherto un. fortunate race of men.

Sir, I have the honor to be, with great respect, your obedient servant,

Hon. C. A. Harris, IsaA MoCor.

Commissioner of Indian Affairs.

[Idem, p. 988- Talk of Special Agent Mason to Cherokee council, at Red Clay, East Tennessee, July $31,1837$.

Brothers, the President hopes you will see the force of the reasons he has given why you can not remain here, and that you will go contentedly and quietly to your new country. The Government will faithfully fulfill all the stipulations and engagements which it has contracted with you, and its earnest desire is to see you, prosperous and happy, and permanently settled in the fine country provided for you, where you will never again be disturbed. Brothers, is there among good men a father who could see his children exposed to dreadful dangers and not make every effort to snatch them away at once and place them in safety 8 The President feels for you as a father for his children. He sees you here exposed to fatal influences which are working for your destruction, and he earnestly desires to place you beyond their reach; hence his anxiety to see you safe in the new and distant country he has set apart for you. Once there and these fatal influences can not reach you. Here you are pent up within narrow limits, and with difficulty many of your people find even a scanty subsistence. There you have a wide country to yourselves, where the indus- 
trious cultivator of the soil will reap his crops in peace and secnrity, and where the hunter will find game in abundance. Here you are subjected to laws, in the making of which you have no voice; laws which are unsuitcd to your customs and abhorrent to your ideas of libertg. There, Cherokees, you will make laws for yourselves, and establish such government as in your estimation may be best suited to your condition. There, Cilherokees, in your new conntry you will be far beyond the limits or jurisdiclion of any State or Torritory. The country will be yours, yours exclusively. No other people can make claim to it, and you will be protected by the vigilant pover of the United States against the intrusion of the white man.

[Senate Ex. Doc. 121, Twenty-fffth Congress, second session, pp. 37. 38, and 39. Letter from E. Boudinot to John Ross November 25. 1836.]

* * * But let us see how you present your objections to some of the details of the treaty; and first your objection to the title which is proposed to be given to the Cherokees for the western country.

The third article of the treaty provides: "The United States also agree that the lands above ceded by the treaty of.February 14, 1833, including the outlet and those ceded by this treaty, shall all be included in one patent executed to the Cherokee Nation of Indians by the President of the United States, according to the provisions of the act of May 28, 1830." The provisions of that act of Congress is as follows: "That in the making of such exchange or exchanges, it shall and may be lawful for the Presiclent solemnly to assure the tribe or nation with which the exchange is made, that the United States will forever secure and guarantee to them, their heirs or successors, the country so exchanged with them, and if they prefer it, that the United States will cause a patent or grant to be made and executed to them for the same: Provided always, That such land shall revert to the United States if the Indians become extinct or abandon the same."

The fifth article of the treaty provides: "The United States hereby covenant and agree that the lands ceded to the Cherokee Nation in the foregoing article shall in no future time without their consent be included within the territorial limits or jurisdiction of any State or Territory. But they shall secure to the Cherokee Nation the right hy their national councils, to make and carry into effect all such laws as they nuy cieem necessary," etc.

These are the premises from which you have formed a most curions inference by a conrse of reasoning which can not even be entitled sophistical. I present these matters only to show how unfair you are even when you pretend to reason. But to illustrate your logic: "The pretended treaty expressly avows," you say, "that it is under the law containing the clause above quoted, and other similar laws, that the trausfer is made, and the Indian title is to be subject, not only to those laws already existing, but to such laws as may be made hereafter." When the treaty refers only to the act of May 28 how do you make out that it "expressly avows" that the transfer is to be made under that law and "other similar lavs," and the Indian title is to be subject to "those laws" and those "which may be made hereafter " "The treaty provides that the lands ceded to the Cherokees "shall in no future time, vithout their consent, be included within the territorial limits or jurisdiction of any State or Territory." Now let us see how gravely and wisely you reason upon that. "Suppose it should suit the policy of the United States, hereafter, to pass a law organizing a territorial government upon the Cherokee lands west? Those laws necessarily destroy the character of the Cherokee Nation as a distinct community; the Nation becoines legally extinct and the lands revert to the United States. The act of May oays, if the Indians becone extinct then the lands shall revert," etc. You infer hence that the law organizing a territorial government upon the Cherokee lands, which can be done only with their consent, according to the treaty, will make the nation extinct, and the lands will hence revert to the United States. This is splendid reasoning, no doubt. It is the first time I have heard Indian extinction to mean legal extinction.

But to state the matter in a short way. According to the provisions of the treaty a patent is to be given by the President of the United States for all the Cherokee lands west, agreeably to the provisions of the act of May 28, 1830 . That act secures those lands to the Cherokees by a guarantee as strong as the United States can make it, with a single proviso, that if the Indians become extinct or remove, then the lands shall revert to the United States. According to the treaty, in no future time is a territorial government to ve formed over these lands, without the consent of the Cherokees. From these plain provisions you build an argument to show that the Indian title is subject, not, only to the act of May, 1830, and to similar acts, but to other acts which may hereafter be made; that if the Government should see fit to organizo a territory over the Cherokee country, tho nation will become legally extinct, and the lands will revert to the United States, and hence the title pretended to be given in the treaty is good for nothing. This no doubt is conclusive ressoning from the premises. 
[House Ex. Doc. No 2, Twenty-fourth Congress, second session, p. 20. Annual message of President Jackson. December 5,1836 .]

* * * The national policy, founded alike in interest and humanity, so long and so steadily pursued by this Government, for the removal of the Indian tribes originally settled on this side of the Mississippi to the west of that river may be said to have been consummated by the conclusion of the late treaty with the Cherokees. The measures taken in the execution of that treaty, and in relation to our Indian affairs generally, will fully appear by referring to the accompanying papers. * * *

[House Ex. Dor. No. 2, Twenty-fourth Congress, second session, p. 370, etc. From Report of Commissioner of Indian Affairs to Secretary of War December 1, 1836.]

* * * The act of Congress of Mar 28, 1830, provided for an exchange of lands with the Indians residing in any part 2 the States or Territories east of the Mississippi and for their removal beyond that river. It authorized the President "solemnly to assure the tribe or nation with which the exchange is made, that the United States will forever secure and guarantee to them, their heirs or successors," the country so exchanged with them ****.

Anterior to the passage of this act, which devolved upon the Executive these high duties to the Indian tribes, the necessity of some form of government had been distinctly recognized. Stipulations were made in treaties with the Cherokees and Choctaws for their removal and settlement west of the Mississippi, in 1817 and 1820. In 1824 Mr. Monroe, in his message at the opening of the session, pointed to the vast extent of country "between the limits of our present States and Territories and the Rocky Mountains and Mexico" as a region to which the Indians "might be invited, with inducements which might be successful." * * * On the 16th December, 1824, the Committee on Indian Affairs was instructed by a resolution of the House of Representatives "to inquire into the expediency of organizing all the Territories of the United States lying west of the State of Missouri and Territories of Arkansas and Michigan into a separate Territory, to be occupied exclusively by the Indians, and of authorizing the President of the United States to adopt such measures as he may think best to colonize all the Indians of the present States and Territories permanently within the same. On the 27th of January, 1825, Mr. Monroe again presented this subject to the House of Representatives in a special message * * *."

Aceompanying this message was a report of Mr. Calhoun, then Secretary of War, in which he stated the obligations of the United States to protect the Indians who should emigrate, to continue to them the means of education and improvement, and to give them "the strongest and most solemn assurance" that the country assigned them should be theirs "as a permanent home for themselves and their posterity."

On the 1st of February, 1825, "a bill for the preservation and civilization of the Indian tribes within the United States" was reported to the Senate by the Committee on Indian Affairs, which finally passed that hody, but did not receive the concurrence of the Honse of Representatives. On December 27, 1825, a resolution was agreed to in the House instructing the Committee on Indian Affairs to inquire into the expediency of establishing some mode for the removal of the Indians, for allotting to each tribe a sufficiency of land "with the sovereignty or right of soil in the same manner that the right of domain is secured to the respective States of the Union" and for establishing there a Territorial government over them, of the same kind and regulated by the same rules, by which the Territories of the United States are now governed."

In January, 1826, the bill, which passed the Senate at the preceding session, was amended by the House Committee on Indian Affairs and transmitted to the Secretary of War, with a request that he would" "afford the committee all such information as is consistent and in the manner you think proper." In compliance with this request, Secretary Barbour transmitted to the committee, on the 3d February, a bill accompanied by an elaborate report explanatory of its principles.

All these official papers agree in their main features. They look to the removal, permanent settlement, and protection of the Indians and the establishment of a Territorial government as measures of vital importance to them, and demanded by a just regard to the obligations of the United States. The treaty with the Cherokees of May 6, 1828, may be considered as the first formal recognition of and action upon these principles, as it secured to them a permanent home under the most solemn guaranty of the United States that it should remain theirs forever, and stipulated that the United States would give them a set of plain laws and cause their lands to be laid off whenever they wished to own them individually.

In the message at the opening of the first session of the Twenty-first Congress President Jackson suggested "the propriety of setting apart an ample district, west of the Mississippi, and without the limits of any State or Territory now formed, to be guarantied to the Indian tribes as long as they shall occupy it, each tribe having 
a distinct control over the portion designated for its use." The act of Congress of May 28, 1830, was the authoritative sanction of both branches of the national legislature to the suggestion of the President. Numerous treaties for the cession and exchange of lands have since been made with Indian tribes, and the entire number of many of them and portions of others have been removed. From a want of exact knowledge of the topography of the country errors have been made in defining the boundaries of the lands intended to be assigned to them, and questions arose which remained long unsettled and proved to be of difficult adjustment. * * *

(Detailed mention is then made of various measures introduced iu Congress between February, 1832, and March, 1836, all of which proved abortive, and the report then proceeds)-

Having completed a review of the action of the executive and legislative branches of the Government upon this subject, noticing only the prominent provisions of the bills that have been before Congress, I beg leave to observe that the aspects, under which it now presents itself, differ materially from those in which it was submitted to Congress in 1825 and 1826 . The plan of removing the Indian tribes from the States and Territories was then comparatively in its infancy. Districts of country west of the Mississippi had boen assigned by treaties to the Choctaws and Cherokees, but only a small number of either tribe had emigrated. And the views of the Executive seem to have been directed to the subject of a government for those who had gone, or might go, more as an ipducement to them to remove, than as a measure immediately demanded for their protection, peace, and prosperity by any existing relations. But the act of May 28, 1830, gave to this matter a new character. It distinctly authorized treaties for the exchange and cession of lands, the conveyance in fee of equivalent tracts to the Indians, and the extension to them at all times of adequate protection. Since its passage the current of emigration has been constantly flowing, with different degrees of rapidity at diffent times.

[Senate Ex. Doc. No. 1, Twenty-fffth Congress, second session, p. 598.]

Statement exhibiting the names of the tribes south and west of the Missouri, and between the Puncah and Red Rivers, the quantity of land held by each, the population of each, and the number of acres for each individual, and the tenure by which the lands are held by them, respectively. (Prepared by the Office of Indian Affairs, Dec. 1, 1837.)

Name of tribe, Cherokees; whole number of acres, 13,800,000; population, 22,000; number acres to each individual, 627 ; tenure, guaranty. Remarks: Treaties of May 6, 1828, February 14, 1833, and January 29, 1835.

[Senate Ex. Doc. 2No. 425, Twenty-fifth Congress, second session, May 7, 1838.]

(Report of the Committee on Indian Affairs, to whom were referred a communica tion from the Acting Secretary of War, dated April 19 last, and the papers which accompanied it, asking that a law may be passed providing for the survey and assignment, in severalty of lands belonging to the immigrated tribes of Indians west of the Mississippi.)

The committee find in this communication a proposition that the United States shall at their expense, have surveyed into small tracts, and set apart, to be held in severalty by individual Indians, the tract of country assignerl and secured to the different Indians tribes who have emigrated west of the Mississippi River.

By the act of May 28, 1830, the Uniterl States stand pledged that they will have the lands west of the Mississippi laid off into districts, and so surveyed and marked tisat each tribe may easily know the boundaries of its own district from that of every other tribe. This pledge it is believed by the committee has been redeemed to every extent that has heretofore been found necessary, and whatever part of it remains unredeemed will without doubt be attended to by the Executive in due season. But so far as the committee are advised, Congress has never held out the idea to any of the tribes that the United States would have partition made of any of those districts and assign to individual Indians the particular tracts that each or any should hold in severalty.

By the third section of the act before referred to, the President of the United States is anthorized to "assure any tribe with which an exchange of lands is made that the United States will forever secure and guarantee to them, their heirs or successors, the country so exchanged with them, and if they prefer it, that the United States will cause a patent or grant to be made and executed to them for the same; Provided always, That such lands shall revert to the United States if the Indians become extinct or abandon the same," 
From the whole tenor of this act it is obvious that the United States intended to provide a permanent home for all such tribes of Indians as then resider within the States or organized Territories as would agree to exchango the lands on which they then lived and remove west of the river Mississippi, and that when settled at their new homes, every reasonable effort should be made to induce them to abandon their roving habits and become cultivators of the soil. They were to remain a distinct and peculiar people, living under and being governed by their own customs and laws, controlled and governed on]y by the United States so far as from time to time might be found necessary for their own security and comfort and the safety and happiness of the citizens of the United States.

Without doubt, the committee believe they ought to be encouraged in a desire to hold their property in severalty, because until indiviluals are satisfied that they and their families will be secured ic the exclusive enjoyment of the fruits of their own labor, it is not to be expected that habits of industry can be acquired to any considerable extent, but at the same time they ought not to be accustomed to look to the Federal Government to supply their wants; on the contrary, they must be taught to look to themselves, to their own nation, for everything within their own favor.

The committee believes these dependent tribes must look to the United States for their titles to the districts of country assigned to them, and that each individual of each tribe who wishes to hold his land in severalty must look to his own tribe for the title by which he is to enjoy his particnlar tract to the exclusion of all others.

Should the United States commence the task of surveying and laying out into townships, iections, half and quarter sections the country assigned to any one tribe, they must in tairness and impartiality pursue the same plan as to all. This would create a large class of new officers and vastly increase the expenditures of the Federal Goverument, and in the end most probably disisatisfy the Indians themselves and operate so as to check all diaposition to look to their own resources to supply their own wants.

In the opinion of the committee, each tribe onght to make such regulations as may best suit its own country and population for a partition of their own land among the individuals, and this at their own expense, and that whenever any one of the tribes may choose to enter upon this business, their agent ought to be instructed to give the best assistanee in his power to enable them to accomplish the object to the satisfaction of their people.

The committee recommend for adoption the following resolution:

Resolved, That it is inexpedient and impolitic for the United States to survey and make partition of the lands assigned to any Indian tribe for the purpose of enabling the individuals of such tribe to hold their lands in severalty, and that such duties ought to be performed by the respective tribes themselves, for the benefit of their own people.

[House Ex. Doc. No. 376, Twenty-fifth Congress, second session, p. 2.]

(From a communication addressed by the Secretary of War to John Ross and others, Cherokee delegation, May 18, 1838.)

'The undersigned has attentively considered the project of a treaty submitted by you

In the next article of your project you jropose that the United States on their part stipulate and agree, in consideration of the premises, to perfect the title of the Cherokee Nation to the lands and territory westward of the Mississippi described. mentioned, and defined in and by the treaty of 1833 between the United States and the Cherokees west of the Mississiri, and the privilege of the outlet thereto annexed, and to issue a patent therefor to the Cherokee Nation in perpetuits. ***

It was always the declarerl intention of the Government to perfect the title to this land to the Cherokee Nation and to issue a patent therefor so soon as that portion of them now east of the Mississippi has emigrated west, granting the nation the privileges secured to them by former arrangements. Nor will it object to grant them in perpetuity, if Congress should think proper to do so on their recommendation, under certain restrictions, to which the delegation have assented. As the delegation have expressed their fears that a form of government might be imposed which they were neither prepared for nor desirous of, the assurance is hereby repeated that no form of government will be imposed upon the Cherokees without the consent of the whole nation, given in council, nor shall their country be erected into a Territory without such previous concurrence. * * *

[Senate Ex. Doc. No. 1, Twenty-fifth Congress, third session, p. 15, etc.]

In his annual message to Congress, December 3, 1838, Prasident Van Buren said:

"It affords me sincere pleasure to be able to apprise you of the entire removal of the Cherokee Nation of Indians to their new homes west of the Mississippi. 
The measures anthorized by Congress at its last session have had the happiust effects.

"The successful accomplishment of this important object * * * has rendered the speedy and successful result of the long established policy of the Government upon the subject of Indian affairs entirely certain. * * * The remedial policy, the principles of which were settled more than thirty years ago under the administration of Mr. Jefferson, consists in an extinction for a fair eonsideration af the title to all the lands still occupied by the Indians within the States and Territories of the United States; their removal to a conntry west of the Mississippi, much more extensive and better adapted to their condition than that in which they then resided; the guaranty to them by the United States of their exclusive possession of that country forever, exempt from all iatrusions by white men, with ample provisions for their security against external violence and internal dissensions, and the extension to them by suitable facilities for their advancement in eivilization. This has not been the policy of particular administrations only, but of each in succession, since the first attempt to carry it out under Mr. Monroe.

"To the Cherokees, whose case has perhaps excited the greatest share of attention and sympathy, the United States have granted in fee, with a perpetual guaranty of exclusive and peaceable possession, 13,544,135 acres of land on the west side of the Mississippi, eligibly situated, in a healthy climate, and in all respects better suited to their condition than the country they have left, in exchange for only $9,492,160$ acres on the east side of the same river.

[House Doc. No. 235, Twenty-eighth Congress, first session.]

(Memorial of John Rogers and others, chiefs and headmen, on behalf of the Cherokee old settlers west of the Mississippi, for themselves and their people, March 30, 1844.)

(P. 12.) * * "As an inducement to us in 1828 to sell out our valuable possessions in Arkansas, the United States agreed not only to convey to us 7,000,000 acres of land, but promised to guaranty it to us forever, 'and (says the treaty) that guaranty is hereby solemnly pledged.

"In the treaty of 1833, it was again stipulated that "the United States agree to possess the Cherokees, and to guaranty it to them forever, and that quaranty is hereby solennly pledged, of $7,000,000$ acres of lands,' and to make the promise more imposing it was added 'and letters patent shall be issued by the United States as soon as practicable for the land hereby guaranteed.'

"These were the promises and solemn pledges of your Government to the Western Cherokees, with whom alone those treaties were made. The patent was not issued 'as soon as practicable,' and in less than three years the solemn pledge to us was so entirely forgotten that your Government, in a treaty with another people, sold them 800,000 acres of land, and agreed to convey it to them and their descendants 'by patent in fee simple,' and at the same time stipulated that our lands, defined and guaranteed to us by the treaty of 1833 , included in the outlet west, should be included in the same patent." * * *

(P. 26.) "We have treated the agreement of the Commissioner as if the treaty of 1828 had actually enlarged the extent of country which the Western Cherokees were before entitled to possess and enjoy. Such, however, is not the fact. The preamble of that treaty adverts to promises made to them in 1818, and confirmed in 1821, of a perpetual outlet west from their possessions in the Territory of Arkansas. The first promise was in the form of a talk from the President to Tolontuskee and a delegation of emigrants under the treaty of 1817. The President said to them: 'The country which you give up is a good country, and it is near and very convenient to us, and I shall in return act genęrously toward you and endeavor to make you happy in your new homes on the Arkansas. I have not yet obtained the land lying up that river, to the west of your settlement. I will give instructions to Governor Clark to hold a treaty with the Quapaws this summer in order to purchase them, and when purchased I will direct them to be laid off for you. It is my wish that you should have no limits to the west; so that you may have good mill seats, plenty of game, and not to be surrounded by the white people.'

"In July, 1821, our chiefs wrote to the Secretary of War, complaining that the promises of the Government in relation to intruders upon our lands and to the outlet to the west had not been performed, and received in reply a letter dated October 8, 1821, in which it was said 'Orders were given some time since for the removal of the whites from your lands and from the tract of country to the west of your reservation, commonly called Lovely's purchase, by which you would obtain the outlet promised.'

"They were then told the orders would be repeated and it was added; "It is to be always understood that in removing the white settlers from Lovely's purchase for the purpose of giving the outlet promised you to the west you acquire thereby no right to the soil but merely to an outlet, of which you appear to be already apprized, 
and that the Government reserves to itself the right of making such disposition as it may think proper in regard to the salt springs upon that tract of country."

"To carry these promises into effect was one of the avowed objects of the treaties of 1828, and 1833, the latter of which describes our title to the land embraced in the outlet as follows, viz:

"The United States further guarantee to the Cherokee Nation a perpetual outlet west, and a free unmolested use of all the country lying west of the western boundary of said 7,000,000 acres, as far west as the sovereignty of the United States, and their right of soil extend: Provided, however, That if the saline or salt plain on the great western prairie shall fall within said limits prescribed for said outlet, the right is reserved to the United States to permit other tribes of red men to get salt on said plain, in common with the Cherokees.'

"Thus the promise of 1818 was that we should be 'without limits to the west' that of 1821 guve us a right to the exclusive possession of the ontlet, with the exception of the salt springs, reserving the right of soil to the United States; the treaties of 1828 and 1833 gave us ' the free and unmolested use' except the salt plain. The lands embraced in the outlet have been treated as Cherokee lands ever since.

"To induce the Eastern Cherokees to sell their possessions and emigrate, Mr. Schermerhorn, at the council of Running Water, August 20, 1835, said to them: "The whole quantity of lands that you will now have west secured by this and other treaties will be $13,800,000$ acres.'

(P. 27) "This quantity embraced the $7,000,000$ defined in the treaty of 1828 , the outlet found to embrace 6,000,000 acres, and 800,000 acres ceded by the treaty of 1885 .

"These evidences are conclusive that from 1818 it was considered by the United States that the Cherokees had an exclusive right to the perpetual and unmolested use of all the lands included in the perpetual outlet, the salt springs excepted. In other words, those lands were as much their own as any others ceded by treaty, the difference in the title being merely nominal.

"In this state of facts what did the Cherokees gain by the treaty of 1828 . Why, they exchanged their own lands in Arkansas for their own lands west of the Arkansas. The United States took the lands which were in their immediate possession, and gave the in payment other lands which were alveady their own. Every foot of the $7,000,000 \mathrm{~m}$ acres, apparently ceded to them in 1828 and 1833 , was part of the outlet of which they were aiready entitled to the 'unmolested use' by the solemn pledges of 1818 and 1821 backed by the expulsion of white settlers therefrom. In fact, all the valuable consideration the Western Cherokees have received for their choice lands in Arkansas, was the $\$ 50,000$, and the other benefits secured by the fifth article, and for the sales of those very lands, the United States have put into the Treasury probably three or four millions of dollars.

"A Amit for a moment that the cession of 1817, 1819, was for the benefit of the whole Cherokee Nation, as the Commissioner of Indian Affuirs maintains; that cession, so intended, included not only our 'acre for acre' grant in Arkunsas, but an outlet west without limits, the whole amounting to seventeen or eigliteen millions of acres. Without the consent of the nation the United States took back, in 1828, over four millions of acres of this 'common property,' giving but 'a peppercoru' therefor, and that not to the right owners. Are they not bound in justice and good faith, now that the nation is reunited, to restore these four or five millions of acres to the Cherokee possessions, thus illegally taken from them?

(P. 32.) "If we are correct in our facts and principles (and we ask for them the closest serutiny) the exclusive right of the Westeru Cherokees to their seven millions acres of land, with the perpetual outlet west, has never been impaired, and their government remains de jure the government of their country to this day. The obligations of the United States to protect them in the possession of their lands and in the perpetual enjoyment of their rights as a distinct people, also remain unimpaired. It is to implore the fulfillment of those obligations, after asking it in vain from the Executive, that an appeal is now made to the Congress of the United States."

[Senate Doc. No. 140, Twenty-eighth Congress, second session.]

(Report of the Secretary of War, February 22, 1845, communicating the report and correspondence of the Board of Inquiry to prosecute an examination into the causes and extent of the discontent and difficulties among the Cherokee Indians:)

[ Statements of Old Settlers, or Western Cherokees, Idem, pp. 87, 88.]

* * Having now shown the existence of two distinct and separate bands of the old Cherokee Nation ever since the year 1809; that they divided their property by the treaty of 1817 and convention of 1819 ; that in 1828 the Western Cherokees treated with the United States for an exchange of lands, as a separate and independent nation, 
and that this nation thus constituted is the sole party in interest with the United States to the treaty of February 14, 1833, the undersigned now submit its provisions for your serious consideration.

The object of the Government in making this treaty, as avowed at the time, was "to adjust and settle boundary lines between the Cherokees and Creeks and other neighboring tribes about which there was some dispute," and also to fix definitely and permanently the boundaries of the Cherokee country in accordance with the provisions of the treaty of 1828 . These boundaries are established by the first article, and a title to the lands in fee simple, confirmed to the Cherokees with the solemn promise on behalf of the United States "that letters patent shall be issued, as soou as practicable, for the land hereby guarantied." This treaty contains no provisions for the admission of the Eastern Cherokees, sumilar to that contained in the fourth article of the Creek treaty concluded at the same time, which expressly provides "that the land assigned to the Muskogee Indians shall be taken and considered as the property of the whole Muskogeo or Creek Nation, as well of those now residing upon the land as the great body of said nation, who still remain on the east ade of the Mississippi." No condition of this kind can be found in the Cherokee treaty. It contains a complete and absolute surrender by the United States to the Western Cherokees of all title to or jurisdiction over the ceded lands. It makes no reference to or reservation under any existing law of the United States, but on the contrary, it repeats by its third article that clause in the treaty of 1828 wherein the United States agree to give the Cherokees a plain set of laws, and survey their lands at the cost of the Government whenerer they desired to own them individually.

The act of Congress of May, 1830, can not affect the tenure of these lands, as no reference is made to it by the treaty under which the Cherokees derive their title, and that law is intended exclusively to enable the President to effect an exchange of lands with the Indians residing east of the Mississippi, for an equal number of acres west of said river, in pursuance of the long-settled policy of the Government. There was no exchange of lands made by the treaty of 1833. It only confirmed the title vested in the Cherokees by the treaty of 1828 , which was concluded two years anterior to the passage of the law referred to. Hence, the undersigned declare the opinion always entertained by these people, that a full and absolute title in fee simple, to the seven millions of acres, with the outlet, passed from the United States to the Cherokees by the treaty of 1833, as fully and effectually as any cession of lands could be made by treaty, concluded between the United States and Spain, or France, or any other government or people. This title was confirmed by the ratification of the treaty on Lpril 12, 1834, and no subsequent law or treaty stipulation ean change it, or impair the rights conveyed and guaranteed without the assent of the Western Cherokees, as a party to such law or treaty.

[House Ex. Doc. 185, Twenty-ninth Congress, first session, p. 4.]

(From report of Indian Commissioner Medell to Secretary of War, March 31, 1846.) * * * At an early period the Cherokees became divided as to their future policy, * * * many had already removed to a country west of the Mississippi * * when in 1817 and 1819 treaties were made with all the parties, by which those west and those who proposed to join them relinquished all their interest in the lands east, and surrendered their proportion of them to the United States, receiving in exchange, acre for acre, about 4,000,000 acres of land lying within the limits of the present State of Arkansas, in addition to which, under a promise of the President, made in March, 1818, and recognized and renewed by the Secretary of War in October, 1821, they were to have the use of the lands immediately west for the purpose of a perpetual ontlet in that direction, as far as the jurisdiction of the United States extended * * * In a few years the progress of the white settlements rendered it important to obtain from the Western Cherokees the lands granted to them by the treaties of 1817 and 1819 . The welfare of the Indians also required that they sliould remove farther west, in order to be free from the harassments and evil effects of being closely surrounded by a white population. Hence the treaty with them of 1828 , by which they agreed to give up the lands referred to, and on which they had made valuable improvements, and to retire farther west upon those to the occupancy of which they were in fact already entitled for the purposes of an outlet. This treaty was made with the "Cherokee Indians west of the Mississippi" without any connection or consultation with the Cherokees east. It gave them in fee simple 7,000,000 eres of land, and guaranteed to them the use of the land immediately west for the purpose of a perpetual outlet as promised by the President and Secretary of War. t also promised that "when they may wish to lay off their lands, and own them inAvidually, a surveyor shall be sent to make the surveys at the cost of the United Stutes.

Some of the lands previously ceded to the Creek Indians having been includol in the cession made to the Western Cherokees by the treaty of 18:8, a treuty supploS. Rep. 281 
mentary to that of 1828 was made with them in February, 1833, as "the Cherokso Nation of Indians west of the Mississippi River" for the purpose of readjusting the boundaries of their lands, and for other purposes. This treaty guaranteed to them forever the lauds clainert and also the perpetual ontlet west and a free and unmolested use of all the country lying west of the said $7,000.000$ acres (the country granted in fee simple) as far as the juriscliction of the United States extends, and it provided that "letters patent should be issued by the United States, as soon as practicable, for the land hereby guaranteed." Thus had they chosen they could, under the provisions of the treaty of 1828, have had their lands divided, and owned them individually, and they conld not then have been dispossessed of any portion of them without the invasion of individual rights, and under the treaty of 1833 they were entitled to a patent, vesting in them as a community the exclusive ownership of the land claimed, separate and wholly distinct from and independent of the Eastern Cherolsees. 